\title{
Annual Report on the Characterization of High-Level Waste Glasses
}

June 1978

Prepared for the U.S. Department of Energy under Contract No. EY-76-C-06-1830

Pacific Northwest Laboratory Operated for the U.S. Department of Energy by 


\title{
NOTICE
}

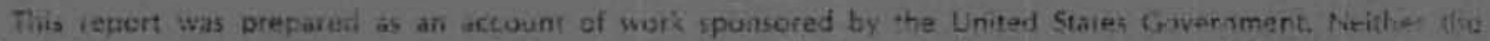
Untied fitatas noi the Cepariment of Enargy. nor any of their employses; nor iny of theit contractars. subcontractars, st their emacyeas, makes any warranty, express ar implieu, or assumes any lagal tiabilin.

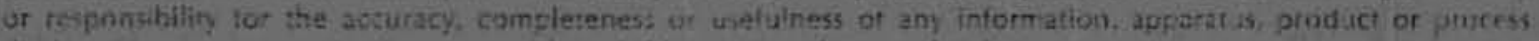
fisclazed, ar represents that ito we wwuid wal latringe privatily owned rights.

The zaws opinions and centusions cantainae in this report are those of the sontisctor and so no: recescarily represent those of toe th wed state: Cuvernment ar the tinited stais Depanmen: of Energy.

\author{
FACIFE NURATWES LABORATOR: \\ siporat by \\ aATitie \\ for the
}

UNITED STATES DEPARIMENT OF ENEFCY

Under Conitact $8 /-76-6$ 06-1335

Printed in she Uloutad seares of Ameita

$$
\text { A. silstile trom }
$$

Gationat Terhrical informanian fervice Linted surme Unyartment of Commetce

$\$ 235$ Fort Royal Rowd

Sphimitried, Virginia 2215 ?

Frice: Prinied Cuays

*: Filerol dete 53.00

\begin{tabular}{|c|c|}
\hline -Paue. & $\begin{array}{c}\text { N715 } \\
\text { Seling Prite }\end{array}$ \\
\hline $601-325$ & $\mathscr{H} \infty$ \\
\hline $025-25 ?$ & 5450 \\
\hline $05:-173$ & 53.15 \\
\hline $0.5,100$ & $\sec c$ \\
\hline 101.125 & viso \\
\hline $115 \times 150$ & 17.15 \\
\hline 151.185 & 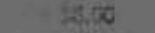 \\
\hline $175+260$ & $\lg (10)$ \\
\hline $207 \cdot 325$ & 69.27 \\
\hline 29,150 & 4,0 \\
\hline 461.23 & $\mathrm{t} 0.73$ \\
\hline $201 x$ & thi:n \\
\hline
\end{tabular}


ANNUAL REPORT ON THE CHARACTERIZATION

OF HIGH-LEVEL WASTE GLASSES
W. A. Ross
D. J. Bradley
J. E. Mendel
L. R. Bunnel1
W. J. Gray
Y. B. Katayama
G. B. Mellinger
F. P. Roberts
R. P. Turcotte
J. W. Wald
W. E. Weber
J. H. Westsik, Jr.

June 1978

Prepared for

the U.S. Department of Energy

under Contract No. EY-76-C-06-1830

Pacific Northwest Laboratory

Richland, Washington 99352 
-

$-$ 


\section{SUMMARY}

A major goal of the Waste Fixation Program at the Pacific Northwest Laboratory is to characterize waste forms and processes for solidification of high-level radioactive wastes. These characterization efforts are directed at both process properties and long-term behavior of waste glasses in aqueous, thermal, and radiation environments. Developments during 1977 shifted from characterizing Plutonium-Uranium Recovery by Extraction (PUREX) wastes to where current emphasis is on Thorium Recovery by Extraction (THOREX) and existing defense wastes.

The waste compositions PW-7c and PW-9 were defined early in 1977 and glass development was completed. A set of experiments was conducted on the effects of major ( \pm a factor of 2 ) variations in the concentrations of principal oxides in the PW-7c waste. The results show that major variations would not grossly affect the leach rates of the glass. In fact, differences are within experimental error.

Impact and strength tests were conducted on samples of nonradioactive glass produced in both laboratory-and engineering-scale equipment and were compared to commercial soda-lime and fused silica glasses. The impact tests showed that the waste glasses compared very well and in general produced slightly less fine particulate than either commercial glass. Strength tests showed that waste glasses had $60 \%$ of the strength of the soda-lime glass. The $\sim 6400$ psi strength of waste glass should be more than adequate for mechanical operations.

Comparative thermal conductivity tests were conducted on a glass in a canister of 2 in. diameter which was water-quenched and thermally cracked. An annealed glass was tested in the same manner. The water-quench reduced thermal conductivity about 20\%. A 24-hr hold at devitrification temperatures did not produce a significant change.

Densities of waste glass were measured at process temperature and were found to be 6.6 to 9.3\% lower than room temperature values. The lower density will 1 imit the fill of canisters and also will provide some driving force for convective gradients in process equipment.

The effects of glass composition on volatility were measured. An addition in $\mathrm{Al}_{2} \mathrm{O}_{3}$ reduced volatility slightly. Addition of $\mathrm{TiO}_{2}$ did not reduce $\mathrm{Cs}$ volatility, as had been expected from other reports, and may have actually increased it slightiy. The effects of additives seem to be related to the effect on viscosity.

Leach testing has emphasized understanding both leach behavior of waste glasses and the leach test itself. Major differences (100X) can be obtained with different leach testing methods. Two leach test parameters which appear to be important are sample form (pellet vs powder) and acid type. The acid tests were performed at pH 4 with a variety of acids. The most corrosive acid was a buffered acetic acid solution. The more recent (lower $\mathrm{ZnO}$ content) formulations have shown much improved resistance to acid attack with little change over the pH 4 to 12 range. Water change or flow rates have also been shown to be important to longterm leach rates.

Leach tests of highly devitrified samples of 72-68 have shown that leach rates of Cs, Sr and $U$ are increased up to $10 X$ and that $\mathrm{Zn}$ leach rates are reduced by nearly $200 \mathrm{X}$. In glass 
76-68, where devitirification rates are much slower, elemental differences between as-formed and thermally-treated samples have not been significant. Average leach rates based on cesium from the 76-68 glass in an IAEA type“long-term test have decreased to $3.3 \times 10^{-8} \mathrm{~g} / \mathrm{cm}^{2} /$ day.

High temperature $\left(250\right.$ and $350^{\circ} \mathrm{C}$ ) leach tests have shown that glass is comparable to other ceramic materials and that all materials corrode at accelerated rates. The tests have shown that: 1) the presence of canister material ( -100 mesh 304 stainless steel) does not affect reaction rates, and 2) the reactions are different in salt brine than in water. In salt brine the glass is rapidly depleted of $\mathrm{CS}, \mathrm{Rb}$ and Mo and these elements stay in solution, presumably as chloride complexes. In water the glass structure is rapidly rearranged to a crystalline structure, and $\mathrm{Cs}$ and $\mathrm{Rb}$ tend to remain bound in the solid.

Leach tests with actual high-level waste 72-68 glass have continued for a second year. Correlation of the leach data with simulated 72-68 waste glass has not shown any effect of the self-contained radiation since values are equivalent.

Detailed devitrification studies on 76-68 glass (low $\mathrm{ZnO}$ ) are being performed. Current (2 mo) results have shown the glass to have slow devitrification kinetics compared to 72-68 glass (high $\mathrm{ZnO}$ ), with only minor changes noted.

A comparison of behavior of the four reference glasses was made utilizing actual HLW. The actual waste had about 10X more uranium than the simulated wastes. The 76-68 and 77-260 glasses after a simulated cooldown were uneffected; however, uranium phases were noted in the 72-68 and 77-107 glasses. The difference between radioactive and simulated wastes can be explained from the different uranium content. Additional cold tests are planned to allow a better comparison. The results support the extensive use of simulated waste glasses. The results also demonstrate that glass compositions can tolerate unanticipated differences in waste compositions.

Examination of both fully radioactive and engineering-scale canisters is showing some segregation during the in-can melting process. Residual crystals in the glass, such as $\mathrm{RuO}_{2}$ and $\mathrm{CeO}_{2}$, are carried upward in the molten glass by escaping gas bubbles. No adverse effect has been identified from this behavior. Reducing agents ( $\mathrm{Si}$ metal) added to in-can melts have been successful in increasing the homogeneity of $\mathrm{CeO}_{2}$ and in eliminating $\mathrm{Na}_{2} \mathrm{MoO}_{3}$ formation. The reduced oxygen potential is affecting the type of crystals which form during devitrification; adverse effects have not been noted.

Radiation effects are accelerated by the use of $\mathrm{Cm}^{244}$. Equivalent exposures to those which would occur in 300,000 years have been obtained in glass samples. The glass buttons still retain their original physical appearance. The tests continue to show that stored energy is not a problem ( $\sim 30 \mathrm{cal} / \mathrm{g}$ maximum) for our HLW glasses. Density changes are being monitored and are small. Both positive and negative changes have been noted of up to 21.2 vol\%, but have not affected the integrity of the samples. The 76-68 glass is one of the better glasses, with only $\sim 0.1 \%$ change. Faster methods to duplicate radiation damage are being investigated but have not been successful to date.

The characterization results continue to indicate that glass is a good waste form and its development should continue. Further tests with the reference glasses will be 1 imited, since increased emphasis is being given to existing defense wastes. 


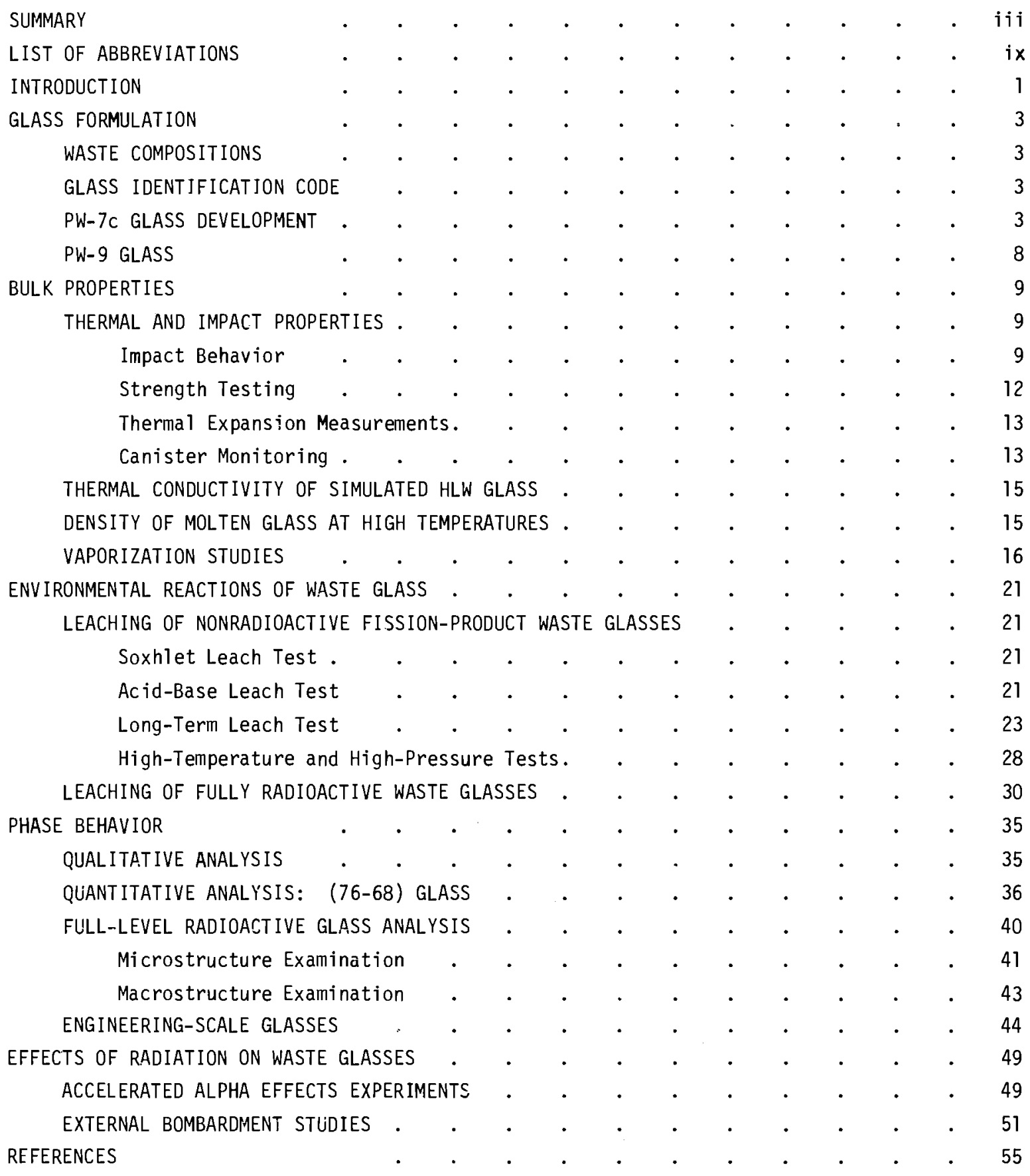




\section{LIST OF FIGURES}

Effects of Composition on Homogeneity and Leach Rate of 77-107 . . . . . 6

Punch-and-Die Arrangement Used for Impact Tests . . . . . . . . . . 9

3 Particle Sizes Produced in Various Glasses by $160 \mathrm{ft}-1 \mathrm{~b}$ Impact . . . . 10

4 Sedimentation Size Analysis Results for Soda-Lime-Silica and ICM-11 Glasses . . . . . . . . . . . . . . . . 11

5 BET Surface Area as a Function of Impact Energy for Soda-Lime-Silica $\quad . \quad$. . 12

6 The Brazilian Diametral Compression Test, Schematic . . . . . . $\quad$. 12

7 Thermal Expansion Curve for Typical Waste Glass (ICM-20) Showing

8 Density of Molten Waste Glasses as a Function of Temperature $\quad . \quad$. $\quad . \quad 16$

9 Density of Waste Glasses, Extrapolated to Lower Temperatures $\quad . \quad$. $\quad$. 17

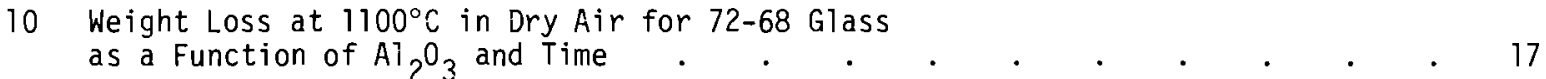

11 Percentage Weight Loss of Te, Mo, Cs, Rb and Ru After $4 \mathrm{Hr}$ in Dry Air. . $\quad 18$

12 Percentage Weight Loss of $\mathrm{B}, \mathrm{K}$, and $\mathrm{Na}$ After $4 \mathrm{Hr}$ in Dry Air . . $\quad . \quad 19$

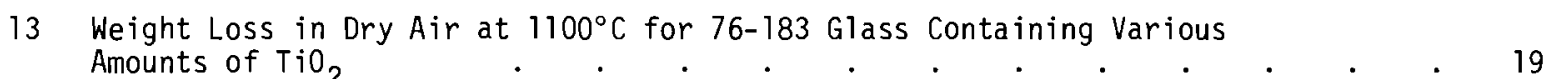

14 Acid-Base Durability of Waste Glasses . . . . . . . . . . . . $\quad$. $\quad 22$

15 Influence of Acid Type on Durability of ICM-11 Glass in PH 4 Solutions . . 23

16 Long-Term Leach Rates Based on CS, Sr, and U for 72-68 Glass . . . $\quad . \quad 24$

17 A Comparison of Devitrification Effects on Leaching of $72-68$ and
$76-68$ Glass
.

18 Long-Term Leach Rates Based on Cs for 76-68 Glass . . . . . . . . . $\quad$. 26

19 Long-Term Leach Rates Based on Sr for 76-68 Glass . . . . . . . . . 26

20 A Comparison of Stagnant Versus Dynamic Leach Test Results . . . . . . 27

21 Leach Rates Based on Cs from Solid and Powdered Samples of 76-68 Glass $\quad$. $\quad 27$

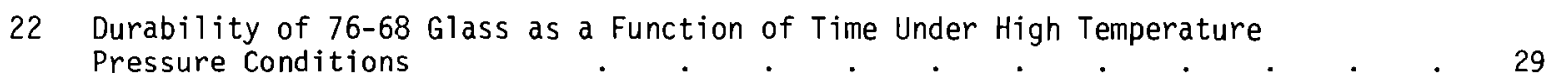

23 Leach Rate as a Function of Time for $\mathrm{Co}, \mathrm{Mn}, \mathrm{Rh}, \mathrm{Eu}$, and $\mathrm{Ce}$. . . . 31

24 Leach Rate as a Function of Time for $\mathrm{Cs}, \mathrm{Sb}, \mathrm{Sr}, \mathrm{Pu}$, and $\mathrm{Cm}$. . . . . 32

25 Cumulative Fraction Leached as a Function of Time . . . . . . . . $\quad . \quad 33$

26 Crystal Yield Versus Cooling Rate . . . . . . . . . . . . . . . . 36

\begin{tabular}{l}
27 X-ray Diffraction Patterns for Glasses After Annealing at $850^{\circ} \mathrm{C}$ \\
for Two Months \\
\hline
\end{tabular}

\begin{tabular}{l}
28 Microstructures for Glasses After Thermal Annealing at $850^{\circ} \mathrm{C}$ \\
for Two Months \\
\hline
\end{tabular}

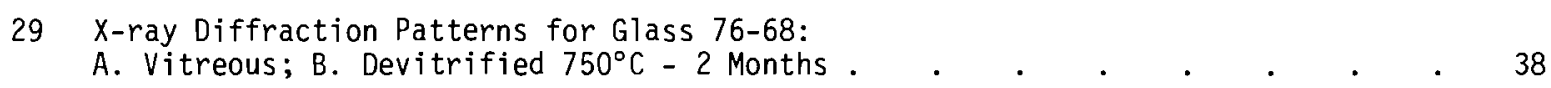

30 Typical Microstructures in Devitrified 76-68 Glass . . . . . . . . $\quad$. 39

31 Growth of Cerium-Uranium Fluorite Phase . . . . . . . . . . . . 39

32 Growth of Iron-Nickel Spinel Phase . . . . . . . . . . . . . 40

33 Typical Microstructure of Vitreous Fully Radioactive Glasses -

34 Full-Level Radioactive Glasses in the Devitrified Condition . . . . . $\quad$. 42 
35 Distribution of Radioisotopes from Burnup of 54,000 MWd/MTU . . . . . $\quad . \quad 44$

36 Sample Location - ICM-23 . . . . . . . . . . . . . . 46

37 Distribution of Crystalline Phases in ICM-23 Glass . . . . . . . . 47

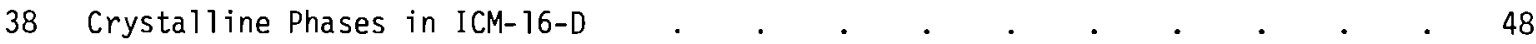

39 Stored Energy Buildup in 72-68 Glass with High Dose . . . . . . . $\quad$. $\quad .50$

40 Comparison of Stored Energy Buildup in European, Lead, 76-68 and . . . . . . . . . . . . . . 50

41 Density Changes in Alpha-Irradiated Glasses . . . . . . . . . . 51

42 Radiation Damage at Saturation Versus Damage at $2 \times 10^{17} \alpha / \mathrm{g} \quad . \quad$. $\quad . \quad 52$

43 Relative Change in the Index of Refraction with Alpha Dose . . . . . . 53

\section{LIST OF TABLES}

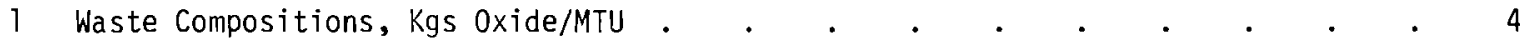

2 Glass Frit Composition, Weight Percent . . . . . . . . . . 4

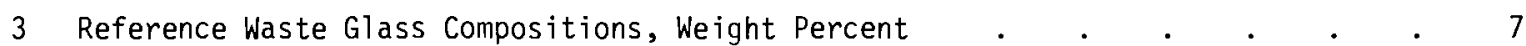

4 Effect of Calcine Composition on Leaching of 77-260

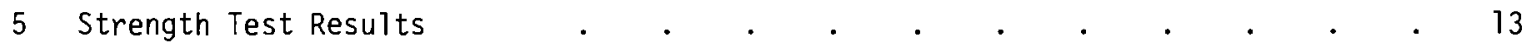

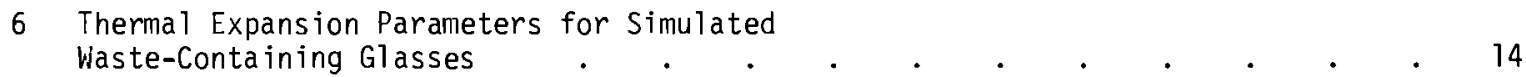

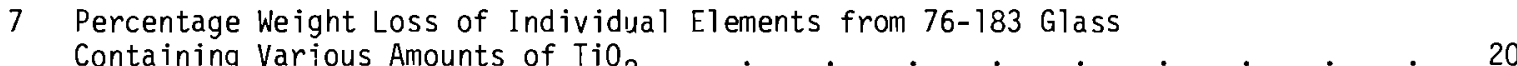

8 Standard Glasses Soxhlet Leach Data After Thermal Storage . . . . $\quad$ - 22

9 Average Long-Term Leach Rates of 72-68 [PW-4b(2.8)73-1] Glass . . . . 24

10 Scouting Autoclave Leach Test Results . . . . . . . . . . . . 28

11 Hydrothermal Glass Reaction Results . . . . . . . . . . . . . . 29

12 Slopes Calculated from Cumulative Fraction Leached Curves . . . . . . 33

13 Main Characteristics of Glasses 72-68,76-68,77-260, and 77-107 . . . 36

14 Lattice Constants Calculated for the Primary Phases in Glass 76-68 . $\quad$. 40

15 Microprobe Analysis of Six Major Constituents in the Full-Level Calcine $\quad$. 42

16 Intercomparison of Glass Frit Components for Fully

17 ICM Glass Types $\quad$ • . . . . . . . . . . . . . . 45

18 Crystalline Phases in ICM Glasses . . . . . . . . . . . . . . . 45 


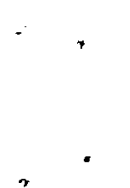




\section{LIST OF ABBREVIATIONS}

ASTM

BET

BNWL

DOE

HLLW

HLW

IAEA

ICM

ILW

LWR

PNL

PUREX

RE

SEM

SAND

THOREX

WFP
American Society for Testing and Materials

Brunauer, Emmett, Teller

Battelle, Pacific Northwest Laboratories

Department of Energy

High-Level Liquid Waste

High-Level Waste

International Atomic Energy Agency

In-Can Melter

Intermedia te-Level Waste

Light Water Reactor

Pacific Northwest Laboratory, operated by Battelle Memorial Institue for the DOE

Plutonium-Uranium Recovery by Extraction

Rare Earth Oxides

Scanning Electron Microscope

Sandia Laboratory

Thorium Recovery by Extraction

Waste Fixation Program 


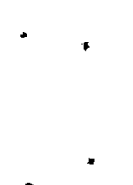

,

$\therefore$

$-1$ 
ANNUAL REPORT ON THE CHARACTERIZATION

OF HIGH-LEVEL WASTE GLASSES

\section{INTRODUCTION}

At the request of the Department of Energy, the Pacific Northwest Laboratory (PNL), operated by Battelle Memorial Institute, issued a Program Plan for the Comprehensive Characterization of Solidified High-Level Wastes in late 1975. (1) This plan was prepared as part of the Waste Fixation Program (WFP), which is directed by PNL. The primary goal of the WFP is to characterize waste forms and processes for the vitrification of high-level radioactive wastes. As designated in the waste characterization program plan, PNL published the first Annual Report on the Characterization of High-Level Waste Glasses in June 1977. (2) This is the second report in the series and is intended to supplement the data in the first annual report.

During the past year, two new reference glasses were developed and introduced into the characterization program; currently four reference glasses are being characterized. Basic process properties are being determined and the behavior of the glasses is being evaluated in leaching, thermal, impact, and radiation environments. This report presents the results of the characterization tests in each of these areas. 
-

. 


\section{GLASS FORMULATION}

This section describes the current waste and glass compositions used in the PNL characterization program. It also includes details on glass formulation selection and effects of variations in waste compositions. Initial scouting tests utilize homogeneity, viscosity and leach rates as criteria for glass quality. These criteria are the basis for the selection of glass compositions for in-depth characterization. Different glass composition types are being selected for each different waste type to provide a range of glass properties to be determined during the characterization activities. This will demonstrate potential 1 imits of property variability and indicate areas of desirable compositions.

\section{WASTE COMPOSITIONS}

During the past year, waste composition PW-7a was updated to PW-7c. The differences in the waste compositions result from changes in flow sheets, regulations, expected burnup, and mixing ratios of intermediate level (ILW) and high-level waste (HLW). The major change was a large increase in $\mathrm{Gd}_{2} \mathrm{O}_{3}$ content due to regulation changes. The $\mathrm{PW}-7 \mathrm{c}$ represents the early years of operation for which burn-up, and subsequently fission product content, is lower. A more careful assessment of the chop-and-leach process showed that zirconium fines from the shearing operation are added to the waste stream. Additional ILW increases $\mathrm{Na}_{2} \mathrm{O}$ and $\mathrm{U}_{3} \mathrm{O}_{8}$, and adds $\mathrm{MnO}_{2}$. Table 1 compares the $\mathrm{PW}-7 \mathrm{c}$ composition to $\mathrm{PW}-7 \mathrm{a}$, $\mathrm{PW}-8 \mathrm{a}$, and $\mathrm{PW}-4 \mathrm{~b}$. The various simulations of the waste composition are noted for laboratory scoping $(-1)$, coldengineering-scale development (-2), detailed characterization $(-3$ and -4$)$, and curium doping for accelerated radiation tests $(-5,-6$, and -7$)$.

Composition PW-9 is also shown ir Table 1. This waste is a relatively clean waste with moderate sodium and uranium concentrations. Calculated for a 40,000 MWd/MTU burn-up, this waste has a higher content of fission products than previous waste compositions.

\section{GLASS IDENTIFICATION CODE}

A standard nomenclature has been used to identify characterization samples to avcid confusion of different waste compositions and mixing ratios. This nomenclature is illustrated by the following example:

$72-68[P W-4 b-1(2.8) 73-1]$

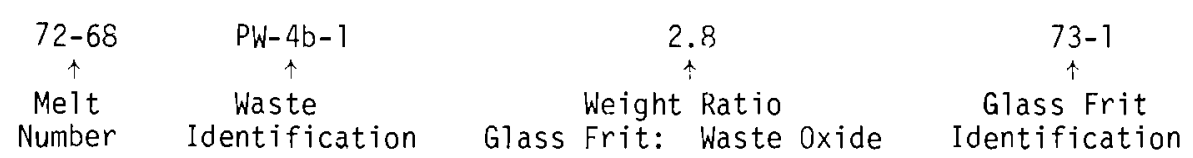

\section{PW-7C GLASS DEVELOPMENT}

Due to the change to $\mathrm{PW}-7 \mathrm{c}$ calcine composition, additional tests were made on the effect of glass composition on leach rate and homogeneity. In these tests, each of the component oxides 
TABLE 1. Waste Compositions, $\mathrm{Kgs} 0 \mathrm{xide} / \mathrm{MTU}(\mathrm{c})$

\begin{tabular}{|c|c|c|c|c|c|c|c|c|}
\hline & & $\begin{array}{l}\text { As Defined } \\
\text { PW- } 4 \mathrm{~b}\end{array}$ & $P W-4 b-7$ & $\begin{array}{l}\text { As Defined } \\
\text { PH-7a } \\
\end{array}$ & $\begin{array}{l}\text { As Defined } \\
\text { PW- } 7 \mathrm{C}\end{array}$ & $P N-7 c-1$ & $P W-7 c-2$ & $\mathrm{PW}-7 \mathrm{c}-3$ \\
\hline \multirow[t]{8}{*}{ Inerts } & $\mathrm{Na}_{2} \mathrm{O}$ & -. & $-\cdot$ & 6.872 & 7.972 & 7.972 & 7.972 & 7.972 \\
\hline & $\mathrm{Fe}_{2} \mathrm{O}_{3}$ & 1.511 & 1.511 & 3.022 & 3.046 & 3.046 & 4.340 & 3.046 \\
\hline & $\mathrm{Cr}_{2} \mathrm{O}_{3}$ & 0.345 & 0.345 & 0.345 & 0.045 & 0.045 & 0.045 & 0.045 \\
\hline & $\mathrm{NiO}$ & 0.141 & 0.141 & 0.141 & 0.020 & 0.775 & 0.775 & 0.020 \\
\hline & $\mathrm{P}_{2} \mathrm{O}_{5}$ & 0.672 & 1.680 & 6.339 & 5.901 & 5.901 & 5.901 & 5.901 \\
\hline & $\mathrm{MnO}_{2}$ & -- & -- & -- & 0.266 & 0.266 & 0.266 & 0.266 \\
\hline & $\mathrm{Gd}_{2} \mathrm{O}_{3}$ & -- & -- & 10.360 & 25.767 & 25.767 & $-(R E)$ & 25.818 \\
\hline & $\operatorname{ZrII}$ Fine $\left(2 \mathrm{rO}_{2}\right)$ & -- & -- & -- & 0.338 & 0.338 & 0.338 & 0.338 \\
\hline \multirow{22}{*}{$\begin{array}{l}\begin{array}{l}\text { Fission } \\
\text { Products }\end{array} \\
\end{array}$} & $\mathrm{Rb}_{2} \mathrm{O}$ & 0.354 & .177 & 0.354 & 0.275 & 0.275 & 0.275 & 0.275 \\
\hline & Sro & 1.059 & 1.059 & 1.059 & 0.724 & 0.724 & 0.724 & 0.724 \\
\hline & $\mathrm{r}_{2} \mathrm{O}_{3}$ & 0.598 & $=\left(C_{m}\right)$ & 0.598 & 0.438 & $0.021(\mathrm{RE})$ & $0.090(\mathrm{RE})$ & 0.438 \\
\hline & $2 \mathrm{rO}_{2}$ & 4.944 & 4. 944 & 4.944 & 3.777 & 3.777 & 3.777 & 3.777 \\
\hline & $\mathrm{MoO}_{3}$ & 5.176 & 6.366 & 5.176 & 3.933 & 4.895 & 4.895 & 4.895 \\
\hline & $\mathrm{TC}_{2} \mathrm{O}_{7}$ & 1.291 & $--\quad(M 0)$ & 1.291 & 1.036 & $--\left(M_{0}\right)$ & $--\left(M_{0}\right)$ & $--\left(M_{0}\right)$ \\
\hline & $\mathrm{RuO}_{2}$ & 2.972 & 1.868 & 2.972 & 2.157 & 2.157 & $\cdots(\mathrm{Fe})$ & 2.157 \\
\hline & $\mathrm{Rh}_{2} \mathrm{O}_{3}$ & 0.480 & 0.480 & 0.480 & 0.405 & $0.257\left(\mathrm{CO}_{0}\right)$ & $0.257(\mathrm{CO})$ & 0.405 \\
\hline & Pdo & 1.483 & 1.483 & 1.483 & 1.237 & $--(\mathrm{Ni})$ & $--\langle N+)$ & 1.237 \\
\hline & $\mathrm{Ag}_{2} \mathrm{O}$ & 0.088 & 0.088 & 0.088 & 0.056 & 0.056 & 0.056 & 0.056 \\
\hline & Cdo & 0.097 & 0.097 & 0.097 & 0.070 & 0.070 & 0.070 & 0.070 \\
\hline & $\mathrm{TeO}_{2}$ & 0.725 & 0.725 & 0.725 & 0.547 & 0.547 & 0.547 & 0.547 \\
\hline & $\mathrm{Cs}_{2} \mathrm{O}$ & 2.880 & 1.440 & 2.880 & 1.989 & 1.989 & $0.665(\mathrm{~K})$ & 1.989 \\
\hline & $\mathrm{BaO}$ & 1.567 & 1.567 & 1.567 & 1.380 & 1.380 & 1.380 & 1. 380 \\
\hline & $\mathrm{La}_{2} \mathrm{O}_{3}$ & 1.480 & $--(\mathrm{cm})$ & 1.480 & 1.127 & 2.332 (RE) & 9.881 (RE) & 1.127 \\
\hline & $\mathrm{CeO}_{2}$ & 3.323 & $--(C m)$ & 3.323 & 2.291 & 4.663 (RE) & 19.763 (RE) & 2.291 \\
\hline & $\mathrm{Pr}_{6}{ }^{0} 11$ & 1.482 & $--(\mathrm{Cm})$ & 1.482 & 1.092 & 0.486 (RE) & $2.059(\mathrm{RE})$ & 1.092 \\
\hline & $\mathrm{Nd}_{2} \mathrm{O}_{3}$ & 4.522 & $--(\mathrm{Cm})$ & 4.522 & 3.613 & 7.652 (RE) & $7.000(\mathrm{RE})$ & 11.644 \\
\hline & $\mathrm{Pm}_{2} \mathrm{O}_{3}$ & 0.123 & $--\quad(\mathrm{Cm})$ & 0.123 & 0.026 & $\ldots(\mathrm{RE})$ & -- (RE) & -- (RE) \\
\hline & $\mathrm{Sm}_{2} \mathrm{O}_{3}$ & 0.924 & $--\langle(\mathrm{Cm}\rangle$ & 0.924 & 0.824 & 0.291 (RE) & $1.240(\mathrm{RE})$ & 0.824 \\
\hline & $\mathrm{Eu}_{2} \mathrm{O}_{3}$ & 0.200 & $--\quad(\mathrm{Cm})$ & 0.200 & 0.141 & 0.078 (RE) & 0.330 (RE) & 0.141 \\
\hline & $\mathrm{Gd}_{2} \mathrm{O}_{3}$ & 0.137 & $--(\mathrm{Cm})$ & 0.137 & 0.087 & 0.194 (RE) & 0.824 (RE) & 0.087 \\
\hline \multirow[t]{5}{*}{ Actinides } & $\mathrm{U}_{3} \mathrm{O}_{8}$ & 1.169 & $--(\mathrm{Cm})$ & 11.689 & 12.899 & 13.743 & -. (Ce) & 13.242 \\
\hline & $\mathrm{NpO}_{2}$ & 0.865 & $=(\mathrm{Cm})$ & 0.865 & 0.167 & $--\quad(U)$ & -- (RE) & $--(U)$ \\
\hline & $\mathrm{PuO}_{2}$ & 0.010 & $--(\mathrm{cm})$ & 0.103 & 0.122 & $--\quad(U)$ & $--(R E)$ & $--(\mathrm{Nd})$ \\
\hline & $\mathrm{Am}_{2} \mathrm{O}_{3}$ & 0.181 & $--(\mathrm{Cm})$ & 0.181 & 0.144 & $--\quad(R E)$ & $\cdots($ RE $)$ & -- (nd) \\
\hline & $\mathrm{Cm}_{2} \underline{0}_{3}$ & $\underline{0.040}$ & $\underline{13.255}$ & 0.040 & 0.007 & $\because \quad(R E)$ & $\ldots$ (RE) & $\ldots--(\mathrm{Nd})$ \\
\hline Total & & 40.84 & 37.2 & 75.86 & 83.92 & 83.70 & 73.47 & 83.87 \\
\hline
\end{tabular}

\footnotetext{
a. Where used, chemical substitutes are shown in parentheses, Values 1 isted represent actual amount present. If no value shown the weight included with substitute. b. $\mathrm{RE}+$ a cormercial rare earth mixture nominally containing wt\% $0.2 \mathrm{Y}_{2} \mathrm{O}_{3}, 24.0 \mathrm{La}_{2} \mathrm{O}_{3}, 48.0 \mathrm{CeO}_{2}, 5.0 \mathrm{Pr}_{6} 011$,
$17.0 \mathrm{Nd}_{2} \mathrm{C}_{3}, 3.0 \mathrm{Sm}_{2} \mathrm{O}_{3}, 0.8 \mathrm{Eu}_{2} \mathrm{O}_{3}$ and $2.0 \mathrm{Gd}_{2} \mathrm{O}_{3}$.

c. Other waste compositions were reported in first annual report BNWL-2252.
} 
TABLE 1. (contd)

\begin{tabular}{|c|c|c|c|c|c|c|c|c|c|}
\hline $\mathrm{PW}-7 \mathrm{C}-4$ & $\begin{array}{l}\text { As Defined } \\
\text { PW-8a }\end{array}$ & $P W-8 a-3$ & $P W-8 a-4$ & $P W-8 d-5$ & $\begin{array}{l}\text { As Defined } \\
\text { PW-9 }\end{array}$ & PW-9-1 & $\mathrm{PW}-9-2$ & PW-9-3 & PW-9-4 \\
\hline 7.972 & 14.057 & 14.057 & 14.057 & 14.057 & 5.857 & 5.857 & 5.857 & 5.857 & 5.857 \\
\hline 3.046 & 27.225 & 27.225 & 27.225 & 26.225 & 1.508 & 1.508 & 3.740 & 1.508 & 1.508 \\
\hline 0.045 & 1.151 & 1.151 & 1.151 & 1.151 & D. 345 & 0.345 & 0.345 & 0.345 & $0.31 / 5$ \\
\hline 0.020 & 0.566 & 0.566 & 0.566 & 0.566 & 0.141 & 0.263 & 0.263 & 0.141 & 0.141 \\
\hline 5.901 & 1.342 & 1.342 & 1.342 & 1.342 & 0.671 & 0.671 & 0.671 & 0.671 & 0.671 \\
\hline 0.266 & -- & -- & -- & -- & -- & -- & -- & - & -- \\
\hline 25.818 & -- & -- & -- & -- & -. & -- & -- & -- & -- \\
\hline 0.338 & -- & -. & -- & -- & -- & -- & -- & -- & -- \\
\hline 0.275 & 0.354 & 0.354 & 0.354 & .354 & 0.424 & 0.424 & $0.213(K)$ & 0.424 & 0.424 \\
\hline 0.724 & 1.059 & 1.059 & 1.059 & 1.059 & 1.214 & 1.214 & 1,214 & 1.214 & 1.214 \\
\hline 0.438 & 0.598 & 0.598 & 0.598 & 0.598 & 0.683 & $0.031\langle$ RE $\rangle$ & 0.039 (RE) & 0.683 & 0.683 \\
\hline 3.777 & 4.944 & 4.944 & 4.944 & 4.944 & 5.589 & 5.589 & 5.589 & 5.589 & 5.589 \\
\hline 4.895 & 5.176 & 6.366 & 6.366 & 6.366 & 5.984 & 7.454 & 7.454 & 7.454 & 7.454 \\
\hline$--\left(M_{0}\right)$ & 1.291 & $--\left(M_{0}\right)$ & $-\left(M_{0}\right)$ & $--\left(M_{0}\right)$ & 1.337 & $--\left(M_{0}\right)$ & $--\left(M_{0}\right)$ & $=$ (MO) & $--\left(M_{0}\right)$ \\
\hline 2.157 & 2.972 & 2.972 & 2.972 & 2.972 & 3.720 & 3.720 & $--(\mathrm{Fe})$ & 3.720 & 3.720 \\
\hline 0.405 & 0.480 & 0.480 & 0.480 & 0.480 & 0.528 & $0.334(\mathrm{CO})$ & $0.334(\mathrm{Co})$ & 0.528 & 0.528 \\
\hline 1.237 & 1.483 & 1.483 & 1.483 & 1.483 & 1.989 & $--(N i)$ & $--(N i)$ & 1.989 & 1.989 \\
\hline 0.056 & 0.088 & 0.088 & 0.088 & 0.088 & 0.079 & 0.079 & 0.079 & 0.079 & 0.079 \\
\hline 0.070 & 0.097 & 0.097 & 0.097 & 0.097 & 0.141 & 0.141 & 0.141 & 0.141 & 0.141 \\
\hline 0.547 & 0.725 & 0.725 & 0.725 & 0.725 & 0.845 & 0.845 & 0.845 & 0.845 & 0.845 \\
\hline 1.989 & 2.880 & 2.880 & 2.880 & 2.880 & 3.356 & 3.356 & $1.122(K)$ & 3.356 & 3.356 \\
\hline 1.380 & 1.567 & 1.567 & 1.567 & 1.567 & 1.913 & 1.913 & 1.913 & 1.913 & 1.913 \\
\hline 1.127 & 1.480 & 1.480 & 1.480 & 1.480 & 1.786 & $3.750\langle$ RE $\rangle$ & $4.660(R E)$ & 1.786 & 1.786 \\
\hline 2.291 & 3.323 & 3.323 & 3.323 & 3.323 & 4.034 & $7.498\langle R E\rangle$ & $9.320(R E)$ & 4.034 & 4.034 \\
\hline 1.092 & 1.482 & 1.482 & 1.482 & 1.482 & 1.802 & $0.781(R E)$ & 0.971 (RE) & 1.802 & 1.802 \\
\hline 11.644 & 4.522 & 4.655 & 12.301 & 4.655 & 5.469 & $2.660(R E)$ & $3.300(\mathrm{RE})$ & 5.692 & 9.552 \\
\hline$--(R E)$ & 0.123 & -- & -- & -- & 0.149 & $--(R E)$ & -- (RE) & $--(G d)$ & $--(G d)$ \\
\hline 0.824 & 0.924 & 0.924 & 0.924 & 0.924 & 1.120 & 0.469 (RE) & $0.593\langle\mathrm{RE}\rangle$ & 1.120 & 1.120 \\
\hline 0.141 & 0.200 & 0.200 & 0.200 & 0.200 & 0.240 & 0.125 (RE) & 0.155 (RE) & 0.266 & 0.266 \\
\hline 0.087 & 0.137 & 0.137 & 0.137 & 0.137 & 0.165 & $0.312(R E)$ & 0.388 (RE) & 0.363 & 0.363 \\
\hline$--(N d)$ & 11.689 & 12.754 & $--(N d)$ & 12.754 & 5.623 & 6.440 & $--(R E)$ & 6.440 & $--(N d)$ \\
\hline$--(N d)$ & 0.865 & $--\langle U\rangle$ & $--(N d)$ & $--\langle u\rangle$ & 0.702 & $--(u)$ & $--\langle R E\rangle$ & $--(U)$ & $\ldots(N d)$ \\
\hline$=(N d)$ & 0.174 & $--(U)$ & $--(N d)$ & $--(U)$ & 0.083 & $--(u)$ & $--(R E)$ & $=(u)$ & $=(N d)$ \\
\hline$--(N d)$ & 0.181 & $--(N d)$ & $--\langle N d\rangle$ & $\ldots(N d)$ & 0.252 & $\ldots(R E)$ & $--\quad(R E)$ & $--(N d)$ & $--(N d)$ \\
\hline$\ldots(N d)$ & 0.040 & $=(\mathrm{Nd})$ & $--(\mathrm{Nd})$ & 9.291 & -0.101 & $\ldots(R E)$ & $=$ (RE) & $\ldots(\mathrm{Nd})$ & $\ldots(N d)$ \\
\hline 78.56 & 93.19 & 92.97 & 87.80 & 102.20 & 57.85 & 55.78 & 49.20 & 57.96 & 55.38 \\
\hline
\end{tabular}


in the frit were increased or decreased, and the $\mathrm{SiO}_{2}$ concentration was varied so that other components remained constant. As shown in Figure 1, the compositions were then examined for homogeneity, and leach rates were determined. The photographs of the melts and crucibles in this figure do not show a major difference in appearance of the melts. Changes of about $2 \%$ in any component from the reference 77-260 composition do not significantly affect leaching of the glass. Details of the reference frit and glass compositions are in Tables 2 and 3 .

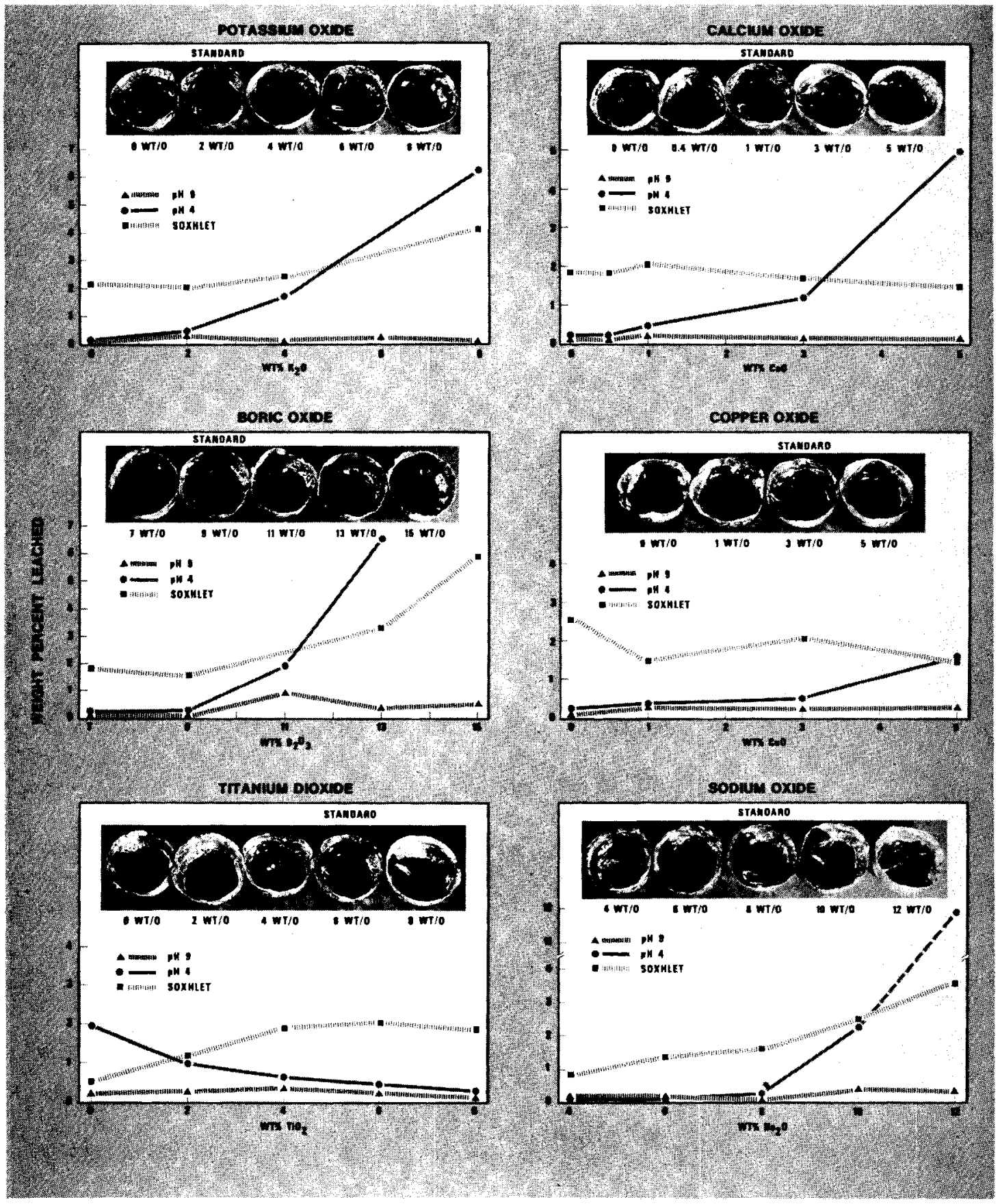

FIGURE 1. Effects of Composition on Homogeneity and Leach Rate of 77-107 
TABLE 2. Glass Frit Composition, Weight Percent

\begin{tabular}{|c|c|c|c|c|c|c|}
\hline & $73-1$ & $\begin{array}{l}75-75 \\
\end{array}$ & $76-101$ & 76-199 & $77-268$ & $77-269$ \\
\hline $\mathrm{SiO}_{2}$ & 37.0 & 38.9 & 59.7 & 53.0 & 56.7 & 53.7 \\
\hline $\mathrm{B}_{2} \mathrm{O}_{3}$ & 15.1 & 15.9 & 14.2 & 14.0 & 19.4 & 13.4 \\
\hline $\mathrm{Na}_{2} \mathrm{O}$ & 5.5 & 0.6 & 11.2 & 12.0 & 3.0 & 11.9 \\
\hline $\mathrm{K}_{2} \mathrm{O}$ & 5.5 & 5.8 & -- & 3.0 & 6.0 & 3.0 \\
\hline Zno & 28.9 & 30.4 & 7.45 & -- & 7.5 & -- \\
\hline $\mathrm{CaO}$ & 2.0 & 2.1 & 3.0 & 3.0 & 3.0 & 1.5 \\
\hline Mg0 & 2.0 & 2.1 & -- & -- & -- & -- \\
\hline Sro & 2.0 & 2.1 & -- & -- & -- & -- \\
\hline $\mathrm{BaO}$ & 2.0 & 2.1 & -- & -- & -- & -- \\
\hline $\mathrm{TiO}_{2}$ & -- & -- & 4.45 & 9.0 & 4.5 & 9.0 \\
\hline $\mathrm{Al}_{2}{ }_{2}{ }_{3}$ & -- & -- & -- & 1.5 & -- & 3.0 \\
\hline CuO & -- & -- & -- & 4.5 & -- & 4.5 \\
\hline
\end{tabular}

TABLE 3. Reference Waste Glass Compositions, Weight Percent

\begin{tabular}{|c|c|c|c|c|}
\hline $\begin{array}{l}\text { Glass Code } \\
\text { Waste Type } \\
\text { Frit Code } \\
\end{array}$ & $\begin{array}{l}72-68 \\
\mathrm{PW}-4 \mathrm{~b} \\
73-1 \\
\end{array}$ & $\begin{array}{l}76-68 \\
\mathrm{PW}-8 \mathrm{a} \\
76-101 \\
\end{array}$ & $\begin{array}{l}77-260 \\
\mathrm{PW}-7 \mathrm{C} \\
77-269 \\
\end{array}$ & $\begin{array}{c}77-107 \\
\mathrm{PW}-9 \\
77-268 \\
\end{array}$ \\
\hline $\mathrm{SiO}_{2}$ & 27.3 & 40.0 & 36.0 & 38.0 \\
\hline $\mathrm{B}_{2} \mathrm{O}_{3}$ & 11.1 & 9.5 & 9.0 & 13.0 \\
\hline $\mathrm{Na}_{2} \mathrm{O}$ & 4.0 & 7.5 & 8.0 & 2.0 \\
\hline $\mathrm{K}_{2} \mathrm{O}$ & 4.0 & -- & 2.0 & 4.0 \\
\hline Zno & 21.3 & 5.0 & -- & 5.0 \\
\hline $\mathrm{CaO}$ & 1.5 & 2.0 & 1.0 & 2.0 \\
\hline $\mathrm{MgO}$ & 1.5 & -- & -- & -- \\
\hline Sro & 1.5 & -- & -- & -- \\
\hline $\mathrm{BaO}$ & 1.5 & -- & -- & -- \\
\hline $\mathrm{TiO}_{2}$ & -- & 3.0 & 6.0 & 3.0 \\
\hline $\mathrm{Al}_{2}{ }^{0} 3$ & -- & -- & 2.0 & -- \\
\hline CuO & -- & -- & 3.0 & -- \\
\hline Was te & 26.3 & 33.0 & 33.0 & 33.0 \\
\hline
\end{tabular}

Some of the components of a waste stream may vary from time to time in the reprocessing operations; thus, variations were determined of single components of the PW-7c waste. Major components were tested at 50,150 , and $200 \%$ of norma 1 concentration in the calcine. All melts contained the normal 33\% total calcine. Table 4 lists the changes in the acid and Soxhlet leach tests for this series; they have been normalized by the leach results of the nominal composition. The changes in leach rate are generally at the limits of experimental error, so differences may only represent experimental uncertainty. We conclude that the glass should tolerate large changes in waste composition without major impact on its initial leach rate. 
TABLE 4. Effect of Calcine Composition on Leaching of $77-260[\mathrm{PW}-7 \mathrm{C}(2.0)$ 77-269] Glass

\begin{tabular}{|c|c|c|c|c|}
\hline \multirow[b]{2}{*}{ Oxide } & \multirow{2}{*}{$\begin{array}{l}\text { Percent of } \\
\text { Nominal } \\
\text { Concentration }\end{array}$} & \multirow{2}{*}{$\begin{array}{c}\text { Actual } \\
\text { Concentration } \\
\text { Weight } \% \\
\end{array}$} & \multicolumn{2}{|c|}{ Relative Leaching } \\
\hline & & & Soxhlet & $\mathrm{pH} 4.0$ \\
\hline $\mathrm{Na}_{2} \mathrm{O}$ & 50 & 1.67 & 0.73 & 1.11 \\
\hline $\mathrm{Na}_{2} \mathrm{O}$ & 150 & 4.55 & 1.38 & 1.60 \\
\hline $\mathrm{Na}_{2} \mathrm{O}$ & 200 & 5.80 & 1.32 & 1.26 \\
\hline $\mathrm{Fe}_{2} \mathrm{O}_{3}$ & 50 & 0.62 & 0.73 & 0.97 \\
\hline $\mathrm{Fe}_{2} \mathrm{O}_{3}$ & 150 & 1.79 & 1.12 & 1.14 \\
\hline $\mathrm{Fe}_{2} \mathrm{O}_{3}$ & 200 & 2.34 & 0.88 & 0.86 \\
\hline $\mathrm{P}_{2} \mathrm{O}_{5}$ & 50 & 1.22 & 0.77 & 0.86 \\
\hline $\mathrm{P}_{2} \mathrm{O}_{5}$ & 150 & 3.40 & 1.20 & 0.71 \\
\hline $\mathrm{P}_{2} \mathrm{O}_{5}$ & 200 & 4.39 & 1.21 & 0.63 \\
\hline $\mathrm{Gd}_{2} \mathrm{O}_{3}$ & 50 & 6.06 & 0.98 & 1.00 \\
\hline $\mathrm{Gd}_{2} \mathrm{O}_{3}$ & 150 & 13.34 & 1.13 & 0.86 \\
\hline $\mathrm{MoO}_{3}$ & 50 & 1.01 & 0.81 & 1.86 \\
\hline $\mathrm{MoO}_{3}$ & 150 & 2.76 & 1.58 & 0.91 \\
\hline $\mathrm{MoO}_{3}$ & 200 & 3.68 & 1.01 & 1.06 \\
\hline $\mathrm{U}_{3} \mathrm{O}_{8}$ & 50 & 2.98 & 1.26 & 0.71 \\
\hline $\mathrm{U}_{3} \mathrm{O}_{8}$ & 150 & 7.59 & 1.37 & 1.00 \\
\hline $\mathrm{U}_{3} \mathrm{O}_{8}$ & 200 & 9.40 & 0.90 & 1.06 \\
\hline $\mathrm{RE}_{2} \mathrm{O}_{3}(\mathrm{a})$ & 50 & 2.05 & 0.85 & 0.94 \\
\hline $\mathrm{RE}_{2} \mathrm{O}_{3}$ & 150 & 5.48 & 0.77 & 0.97 \\
\hline $\mathrm{RE}_{2} \mathrm{O}_{3}$ & 200 & 6.93 & 1.00 & 1.20 \\
\hline
\end{tabular}

(a) $\mathrm{RE}=$ Rare Earth oxides.

\section{PW-9 GLASS}

The development of a preliminary PW-9 composition, 76-375[PW-4b-1(2.0) 77-62], was reported in the 1977 annual report and has also been detailed in an additional report. (3)

Further tests with the actual PW-9 waste did not significantly modify the final glass composition. The major change is less $\mathrm{Na}_{2} \mathrm{O}$ in the frit, which is compensated for by additional $\mathrm{Na}_{2} \mathrm{O}$ in the waste and $\mathrm{SiO}_{2}$ in the frit. The composition is now identified as $77-268[\mathrm{PW}-9(2.0)$ 77-107]. (The compositions of the frit and glass are shown in Tables 2 and 3.) One potential problem with this composition is that it has marginal tolerance toward sodium molybdate separation, even though the boron oxide concentration is higher than other glasses. For process operations, we may have to utilize reducing agents or limit waste loading to less than $33 \%$. 


\section{BULK PROPERTIES}

In the 1977 Annual Report, ${ }^{(2)}$ we defined the bulk properties of the glass compositions studied for vitrification. This year, our work on bulk properties of these glasses centered on thermal and impact properties, homogeneity, density, vaporization, and thermal conductivity. These properties are important in considering process and equipment design, glass crystallization kinetics, and mechanical impact during possible accidents.

\section{THERMAL AND IMPACT PROPERTIES}

To date, waste glass is similar in behavior to soda-lime-silica and is superior to it in terms of new surface created at high energies. A simple test for determining strength has been used to evaluate simulated waste-containing glass. Thermal expansion of numerous glasses was measured, and cracking was studied in large diameter (to 36 in.) canisters.

\section{Impact Behavior}

As a consequence of handling and shipping, waste canisters may occasionally be subjected to impacts. To learn the consequences of impact, drop tests were made on canisters containing simulated waste-containing glass. ${ }^{(4)}$ The purpose of this study was to devise a laboratoryscale impact test and use it to compare various types of glass for eventual hot-celi verification.

The impact behavior of various model and simulated waste-containing glasses was examined by impacting a right circular cylindrical specimen ( $0.440 \mathrm{in.} 00 \times 0.50 \mathrm{in}$. 1ong) in the punch-anddie arrangement of Figure 2 . The die diameter was purposely oversized for minimal restraint to the glass fracture, and the punch contained swirl chambers to decrease the amount of fine material

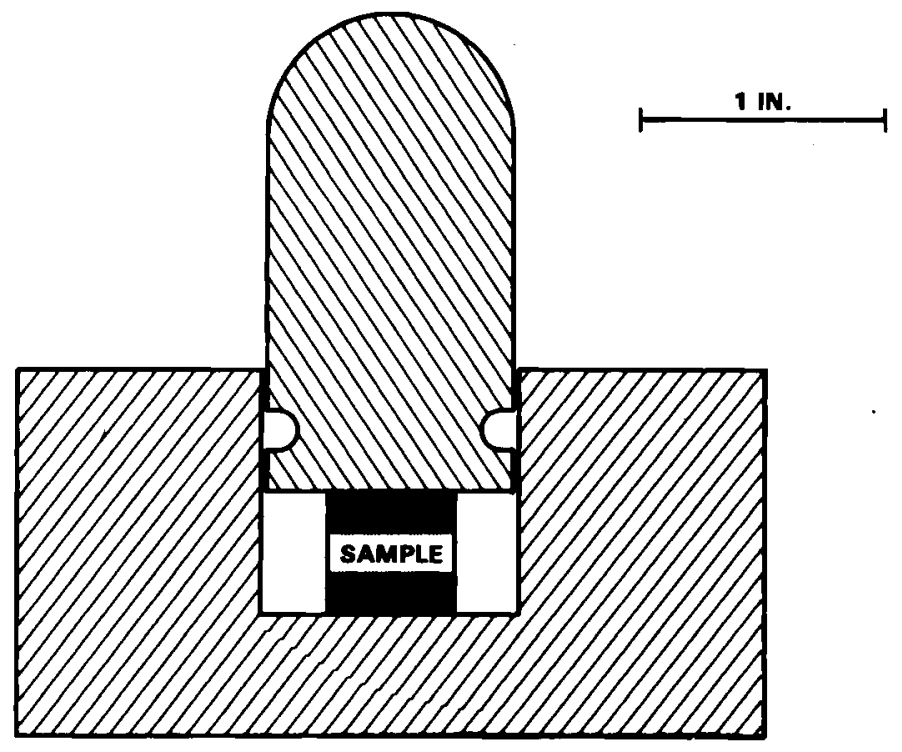

FIGURE 2. Punch-and-Die Arrangement Used for Impact Tests 
ejected during impact. The punch was struck by either a weight running on linear ball-bearings (160 ft-1b maximum energy) or by a freefalling $100 \mathrm{lb}$ weight ( $1400 \mathrm{ft}$-1b maximum to date). The fine particles produced were sized by two methods: sieving for $>44 \mu \mathrm{m}$ particles, and a sedimentation technique for smaller particles. In addition, the surface area was determined as a function of impact energy for two glasses.

Figure 3 shows the particle sizes produced in several different glasses by impact at $160 \mathrm{ft}-1 \mathrm{~b}$. This figure and similar plots show that:

- Vitreous silica is the worst performer on impact.

- The curves are roughly parallel, so the various glasses differ mainly in their fines production, despite the wide compositional variations represented.

- The stacking order is the same from $20 \mathrm{ft}-1 \mathrm{~b}$ to $160 \mathrm{ft}-1 \mathrm{~b}$, noted by comparing several plots at $20,40,80$, and $160 \mathrm{ft}-1 \mathrm{~b}$.

- The devitrified 9091 IQY Corning glass does not behave significantly better than the same glass in the vitreous state.

- Simulated waste-containing glasses are similar in impact behavior to their host frits.

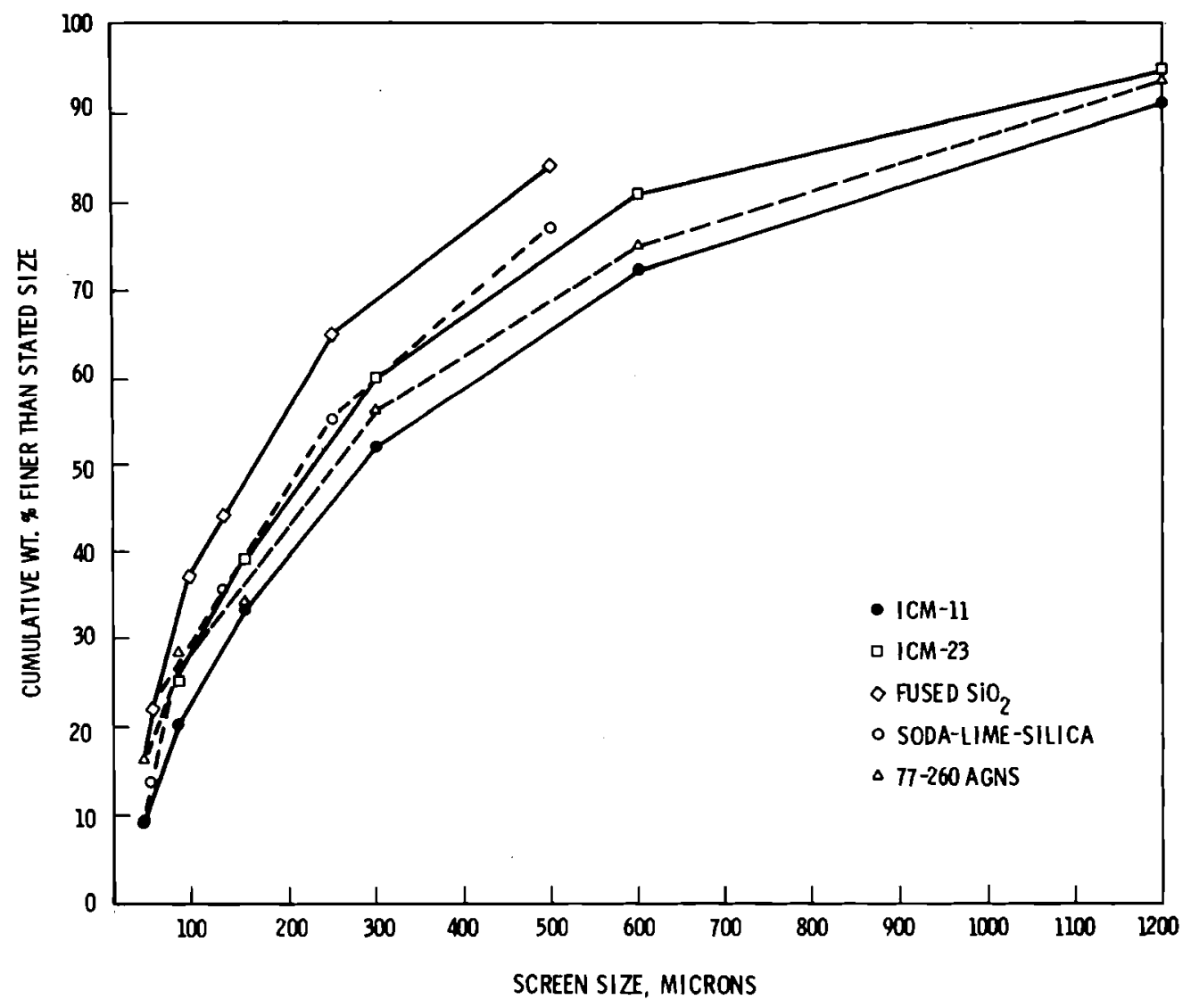

FIGURE 3. Particle Sizes Produced in Various Glasses by $160 \mathrm{ft}$-lb Impact 
Figure 4 shows fine particle sedimentation(a) analysis for soda-lime-silica and ICM-11 [PW-7-2(2.0)73-1] glasses impacted at $160 \mathrm{ft}-1 \mathrm{~b}$, fines fraction $(-44 \mu \mathrm{m})$ only. A single impact produced only a small amount of the $-10 \mu \mathrm{m}$ fines. For soda-lime-silica glass, this fraction is $(20 \%$ a $-44 \mu \mathrm{m} \times 14 \%-10 \mu \mathrm{m})=2.8 \%$; for ICM-11 glass, it is $2.4 \mathrm{wt} \%$.

If a simple relationship existed between impact energy and the resulting surface area, analysis would be simplified. Using the Brunauer, Emmett, Teller (BET) method, we determined the surface areas for soda-lime-silica glass. Results in Figure 5 are roughly linear with impact energy, as is ICM-11 glass at energies less than $160 \mathrm{ft}-1 \mathrm{~b}$. At $1400 \mathrm{ft}-1 \mathrm{~b}$, the $1 \mathrm{CM}-11 \mathrm{glass}$ shows a distinctly lower surface area production. We will closely watch this trend with other candidate glasses.

We also used BET surface areas of fractured soda-lime-silica to calculate the percentage of the impact energy actually used in creating new surface. A specimen fractured with $48.5 \mathrm{ft}-1 \mathrm{~b}$ (65.8 joules) of energy had a measured surface area of $0.056 \mathrm{~m}^{2} / \mathrm{g}$, while a specimen fractured at $158.4 \mathrm{ft}-1 \mathrm{~b}$ (214.9 joules) had a surface area of $0.117 \mathrm{~m}^{2} / \mathrm{g}$. Considering the three-gram sample involved in each case, this translates to $2.55 \times 10^{-3} \mathrm{~m}^{2} /$ joule in the former case, $1.64 \times 10^{-3}$ $\mathrm{m}^{2} /$ joule in the latter. A value of 3.85 joule $/ \mathrm{m}^{2}$ is reported ${ }^{(5)}$ for the surface energy of sodalime-silica glass at room temperature. This corresponds to $2.6 \times 10^{-1} \mathrm{~m}^{2} /$ joule. As expected, the impact process is apparently complex enough that only $1 \%$ of the available energy is used in creating new surface area.

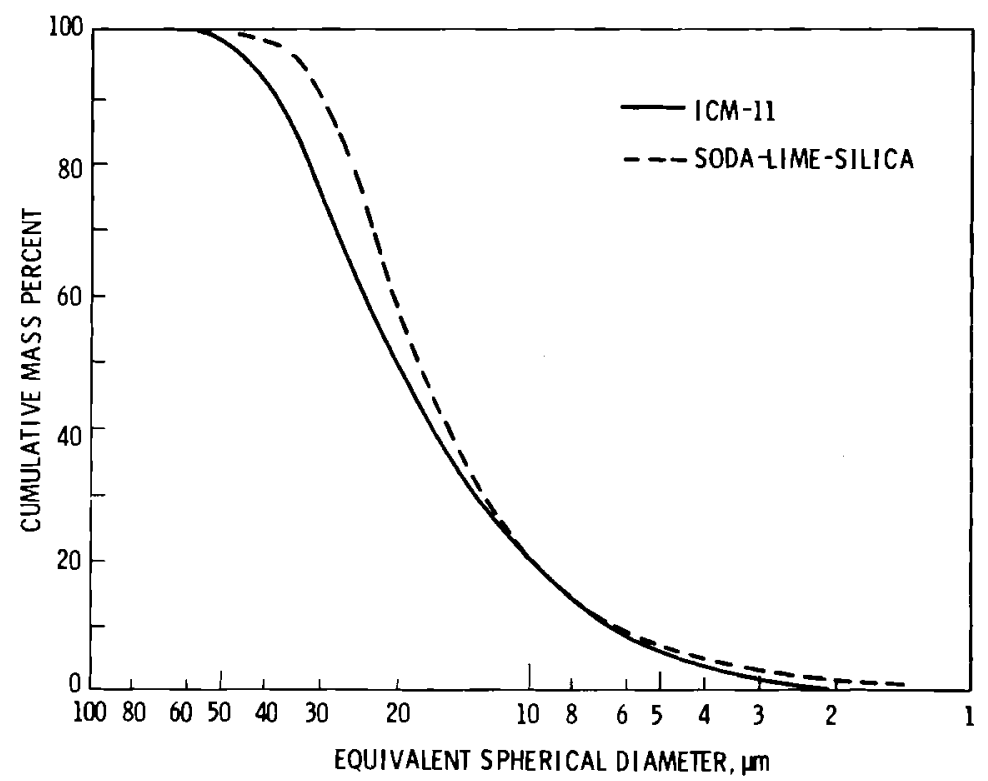

FIGURE 4. Sedimentation Size Analysis Results for Soda-Lime-Silica and ICM-11 Glasses

(a) Sedigraph 5000, Micrometrics Corporation. 


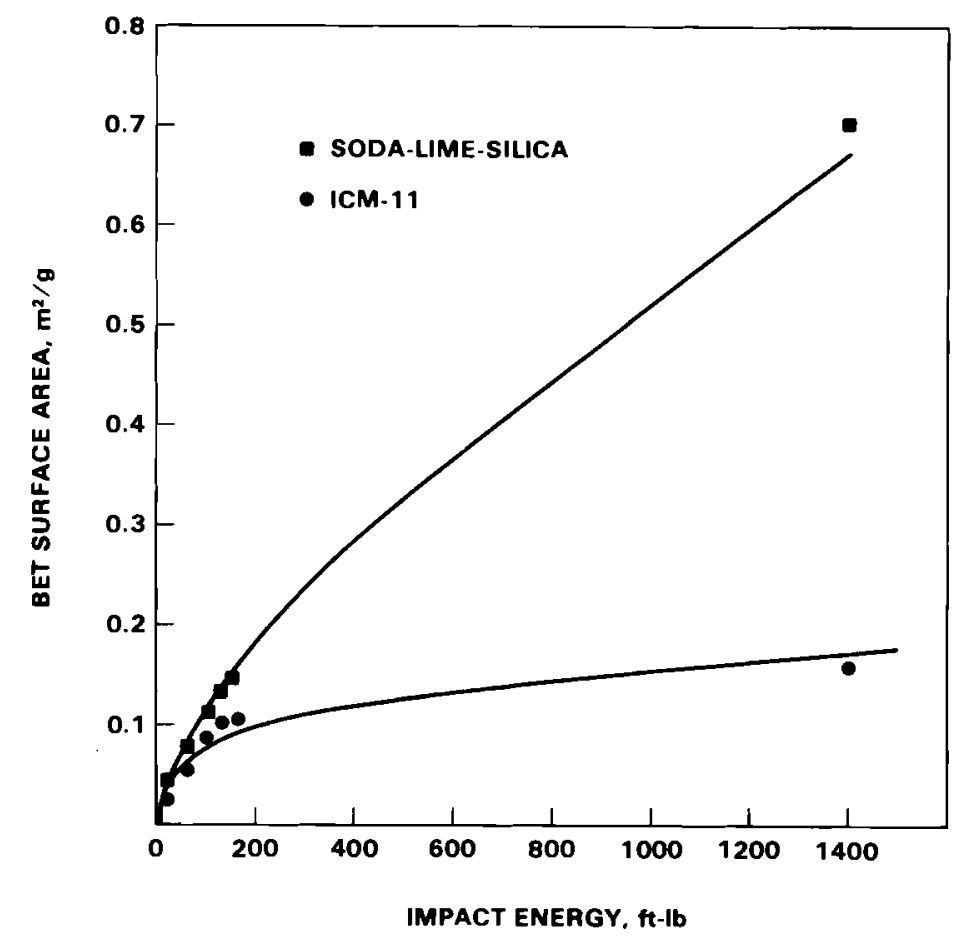

FIGURE 5. BET Surface Area as a Function of Impact Energy for Soda-Lime-Silica and ICM-ll Glasses

\section{Strength Testing}

Strength tests on brittle materials usually require careful specimen preparation, a difficult feat in the hot-cell. Since core-drilled samples are usually most easily available, an ideal test would use these samples with minimum further preparation. The ideal specimen would be self-aligning to minimize parasitic bending moments, which can cause errors. A configuration which meets these requirements is the Brazilian test, shown in Figure 6 , in which a right circular cylinder is loaded on its diameter. An American Society for Testing and Materials (ASTM) test for concrete, C496-64T, uses this concept. Rolling aligns the cylinder in one

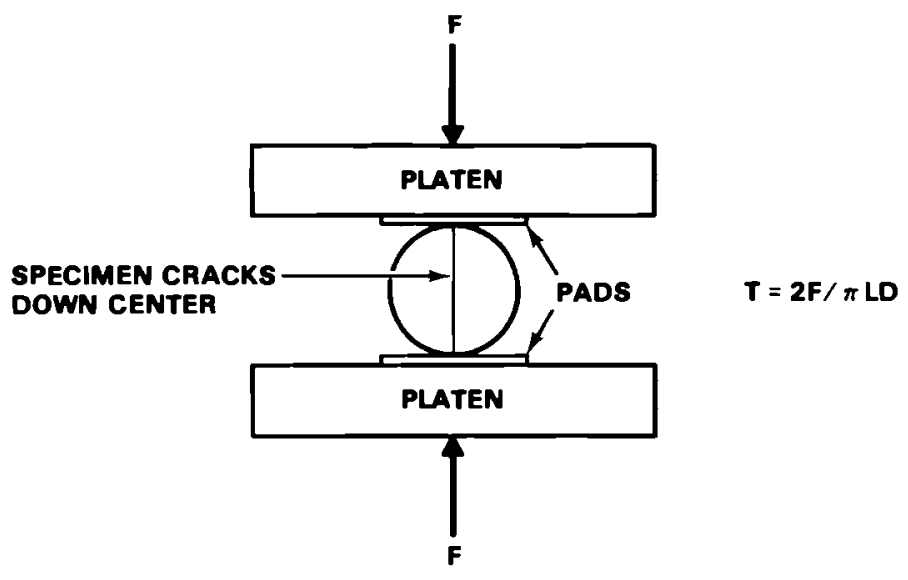

FIGURE 6. The Brazilian Diametral Compression Test, Schematic 
direction, and an additional roller aligns it in the other. This test has been used by other workers in the nuclear waste field ${ }^{(6)}$ and seems well suited.

To use the Brazilian test successfully, the very high stresses at contact points must be eliminated by a suitable pad material. The stresses are high enough to penetrate most metals, but our testing showed that 1/16 in. thick balsa wood with its grain perpendicular to the load line was the best material tested. Only a small number of ICM-11 glass and soda-lime-silica specimens have been tested to date; Table 5 summarizes these results. The standard deviations, although higher than desired, are typical of glass results in general since the material is flaw-sensitive.

TABLE 5. Strength Test Results

\begin{tabular}{|c|c|c|c|}
\hline Glass Type & $\begin{array}{l}\text { Number of } \\
\text { Specimens }\end{array}$ & $\begin{array}{c}\text { Average Strength, } \\
\text { psi }\end{array}$ & $\begin{array}{c}\text { Standard Deviation, } \\
\text { psi }\end{array}$ \\
\hline Soda-lime-silica & 11 & 10,870 & 1400 \\
\hline ICM-11 [PW-7-3(2.0)73-1] & 10 & 6,303 & 1370 \\
\hline
\end{tabular}

\section{Therma 1 Expansion Measurements}

The thermal expansion parameters of a large number of glass samples from both ICM canisters and laboratory-prepared materials were determined using a push-rod dilatometer. All heating was done in air, at $4^{\circ} \mathrm{C} / \mathrm{min}$. A typical plot is shown in Figure 7 , which $i 11$ ustrates some of the characteristic parameters of a sample. These parameters are:

- the thermal expansion coefficient, determined from the slope of the linear portion of the curve, generally RT $-400^{\circ} \mathrm{C}$;

- $T_{G}$, the glass transition temperature, the point at which the thermal expansion rises sharply, corresponding to a change to the supercooled liquid state; and

- $T_{S}$, the dilatometric softening point, the temperature at which the push-rod sinks into the sample.

Table 6 lists the expansion parameters for the types of glass which were measured. When several samples were measured from a single canister, representative numbers were selected from the data; in most cases in-canister variations were smal1. Most of the expansion coefficients were fairly close to $10 \times 10^{-6} /{ }^{\circ} \mathrm{C}$, but the other two parameters varied somewhat. The parameters in Table 6 are intended for use in design calculations and as general characterization.

\section{Canister Monitoring}

The high thermal expansion coefficient of the waste glass compositions, the thermal expansion mismatch with the canister metals, and the large canisters being considered virtually assure that crack-free glass will not be produced using a "reasonable" cooling cycle. Calculations indicate that a controlled cooling of several months could be required. The effect of heat-producing waste complicates matters further; thus, a "monolith" will not be produced by either the ICM or ceramic melter processes without changes in handling, canister geometry, annealing schedules, etc. 


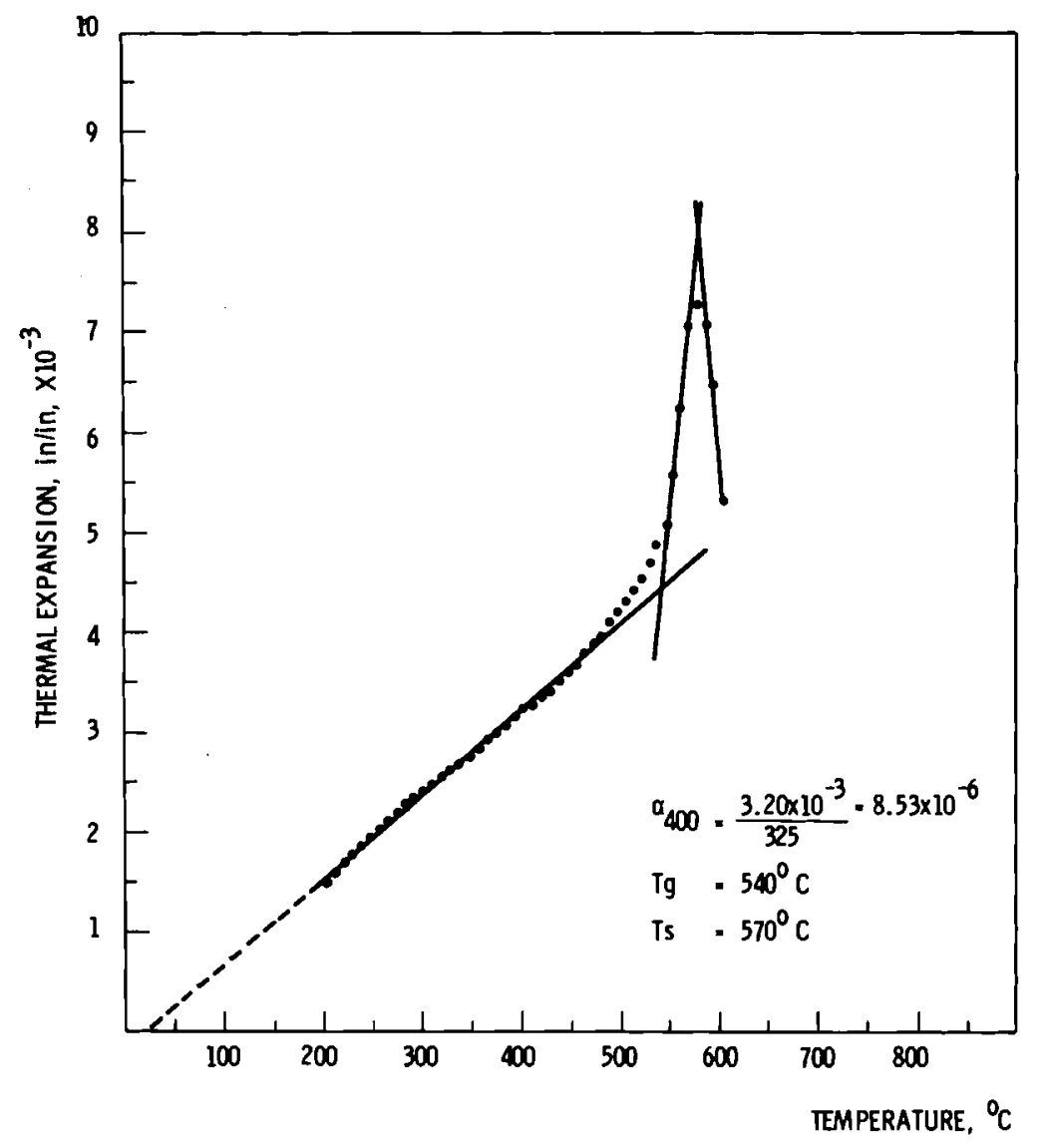

FIGURE 7. Thermal Expansion Curve for Typical Waste Glass (ICM-20) Showing Characteristic Temperatures and Expansion Parameters

TABLE 6. Thermal Expansion Parameters for Simulated Waste-Containing Glasses

\begin{tabular}{|c|c|c|c|}
\hline Glass Designation & $\begin{array}{l}\alpha, \mathrm{RT}-400^{\circ} \mathrm{C}, \\
\times 10^{-6} /{ }^{\circ} \mathrm{C} \\
\end{array}$ & $I_{G},{ }^{\circ} \mathrm{C}$ & $\mathrm{I}_{S},{ }^{\circ} \mathrm{C}$ \\
\hline $72-68[P W-4 b-6(3.0) 73-1]$ & 9.39 & 495 & 540 \\
\hline $73-1$ frit & 8.13 & 510 & 560 \\
\hline 76-101 frit & 7.20 & 563 & 615 \\
\hline $77-260[\mathrm{PW}-7 \mathrm{C}-3(2.0) 77-269]$ & 10.0 & 525 & 575 \\
\hline ICM-11 [PW-7-2(2.0)73-1] & 9.33 & 520 & 565 \\
\hline $\begin{array}{c}\text { ICM-16[PW-7a-2(2.0)- } \\
75-75+1.5 \% \mathrm{Si}]\end{array}$ & 8.4 & 537 & 574 \\
\hline $\begin{array}{c}\text { ICM- } 18[\text { PW- } 8 \mathrm{a}-2(2.0)- \\
75-75+1.5 \% \mathrm{Si}]\end{array}$ & 9.2 & 525 & 558 \\
\hline $\begin{array}{c}\text { ICM-20[PW-7a-2(2.0)- } \\
75-75+1.5 \% \mathrm{Si}]\end{array}$ & 8.4 & 545 & 583 \\
\hline $\begin{array}{l}\text { ICM-2 }[\text { PW-7a-2(2.4)- } \\
\quad 75-75+0.5 \% \mathrm{SiC}]\end{array}$ & 9.0 & 526 & 559 \\
\hline $\begin{array}{c}\text { ICM-23[PW-7a-2(2.0)- } \\
76-199+1.5 \% \mathrm{Si}]\end{array}$ & 10.0 & 530 & 586 \\
\hline
\end{tabular}


Since the glass will not be crack-free, reasonable questions to ask are:

1) How much is the surface area available for leaching increased by the cracking?

2) How much dispersible material $(<10 \mu \mathrm{m})$ is generated?

Answering these questions for a 36-in. diameter canister full of glass is no small task. Several large canisters 16 to $36 \mathrm{in}$. in diameter, filled with glass using the electric melting furnace, were cut open, sampled, and sized.

The glass was not bonded to the mild steel canisters but was cracked into 3 to 4 annular shel ls $1 / 16$ to $1 / 4 \mathrm{in}$. thick immediately adjacent to the can wall. These shells are partially a result of not heating canisters during pouring. The extent of the cracks might be lessened by heating the can to near the softening point of the glass during pouring. Although the glass fragments were small at the surface, they became progressively larger toward the can centers and were 4 to $6 \mathrm{in}$. in diameter there. We estimate that the surface area of the fragments is approximately $15 \mathrm{X}$ the original geometric surface area.

\section{THERMAL CONDUCTIVITY OF SIMULATED HLW GLASS}

Thermal conductivity was measured on 77-107 [PW-9-1(2.0)77-268] glass using a steady-state radial heat-flow technique. The neat-flow apparatus was of a preliminary design, constructed to determine the effectiveness of the technique. The glass was measured between 50 and $1000^{\circ} \mathrm{C}$, then the effects of devitrification and thermal shock were studied.

Devitrification was induced by holding the sample at $800^{\circ} \mathrm{C}$ for $24 \mathrm{hr}$. No change in thermal conductivity was noted. The effects of thermal shock on thermal conductivity was determined by two quenching experiments. In the first experiment, the sample was cooled from $600^{\circ} \mathrm{C}$ in air and no change in conductivity occurred. In a second test, the sample was quenched in water, and a $20 \%$ drop in conductivity was measured. This was caused by cracking of the glass, the cracks acting as barriers to heat flow. These experiments suggest that neither devitrification nor quenching causes major changes in the heat transfer characteristics of waste glass castings.

\section{DENSITY OF MOLTEN GLASS AT HIGH TEMPERATURES}

.As part of studies on actual melting of the waste glasses, we measured the molten densities of standard $\mathrm{g}$ lasses 72-68 [PW-4b-2(2.8)73-1], 77-260 [PW-7c-1(2.0)77-269], 77-107 [PW-9-1(2.0)77-263], and 76-68 [PW-8a-1(2.0)76-101]. Densities were calculated from the buoyant force exerted on a $2 \mathrm{~cm}^{3}$ platinum cylinder suspended in the glass. The densities were measured at temperatures from 1050 to $1300^{\circ} \mathrm{C}$. Lower temperature measurements were not practical with this method due to the increasing viscosity of the glass as the temperature was lowered. Room temperature densities were also measured, using water immersion.

The density values of the molten glasses are plotted as a function of temperature in Figure 8 . The density curves are replotted in Figure 9 and extrapolated to lower temperatures in the molten region. Figure 9 also shows the solid densities of the glasses, calculated from their room temperature densities and approximate thermal expansions. In a crystalline material, the transition between solid and liquid is a sharp one, occurring at a particular temperature. 


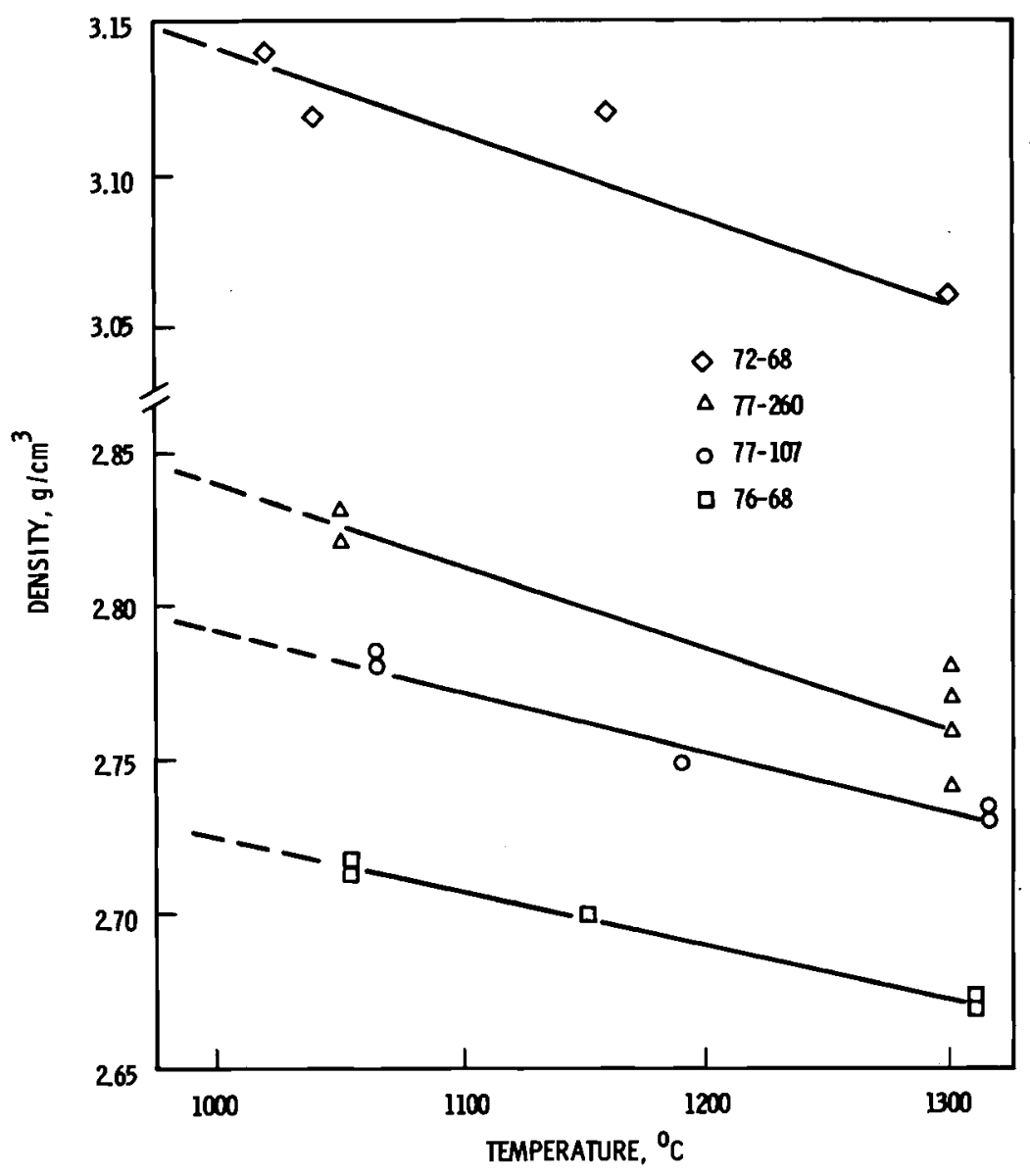

FIGURE 8. Density of Molten Waste Glasses as a Function of Temperature

In silicate glasses, the transition occurs gradually over a range of temperatures. The dashed lines in Figure 9 may indicate the density of the glasses in this region. Tool found this type of "S" shaped curve for another silicate glass. (7)

The higher solid and molten density of $72-68$ glass is due to its high Zno content, $21 \mathrm{wt} \%$. The other glasses contain 0.0 to $7.5 \mathrm{wt} \% \mathrm{ZnO}$. The difference in room temperature and $1050^{\circ} \mathrm{C}$ densities of these glasses range from 6.6 to $9.3 \%$.

\section{VAPORIZATION STUDIES}

Presently the volatility of potential waste forms is being studied to help estimate the effects of high temperatures on the glass, such as during processing or during a fire with a breach of containment in shipment or storage. Methods of reducing volatility, particularly of cesium, are also being studied.

The results of a study on vaporization for the waste glass 72-68 have been published previously, as well as a description of the apparatus used, experimental procedures, and treatment of data. ${ }^{(8)}$ As a continuation of this study, we are investigating the effect of additives on the volatility of cesium and other elements.

Figure 10 shows weight-loss results at $1100^{\circ} \mathrm{C}$ for $72-68[\mathrm{PW}-4 \mathrm{~b}-3(2.8) 73-1] \mathrm{glass}$ with $\mathrm{Al}_{2} \mathrm{O}_{3}$ additions ranging from 0 to $15 \mathrm{wt} \%$. Weight-loss rates were reduced by a factor of about 


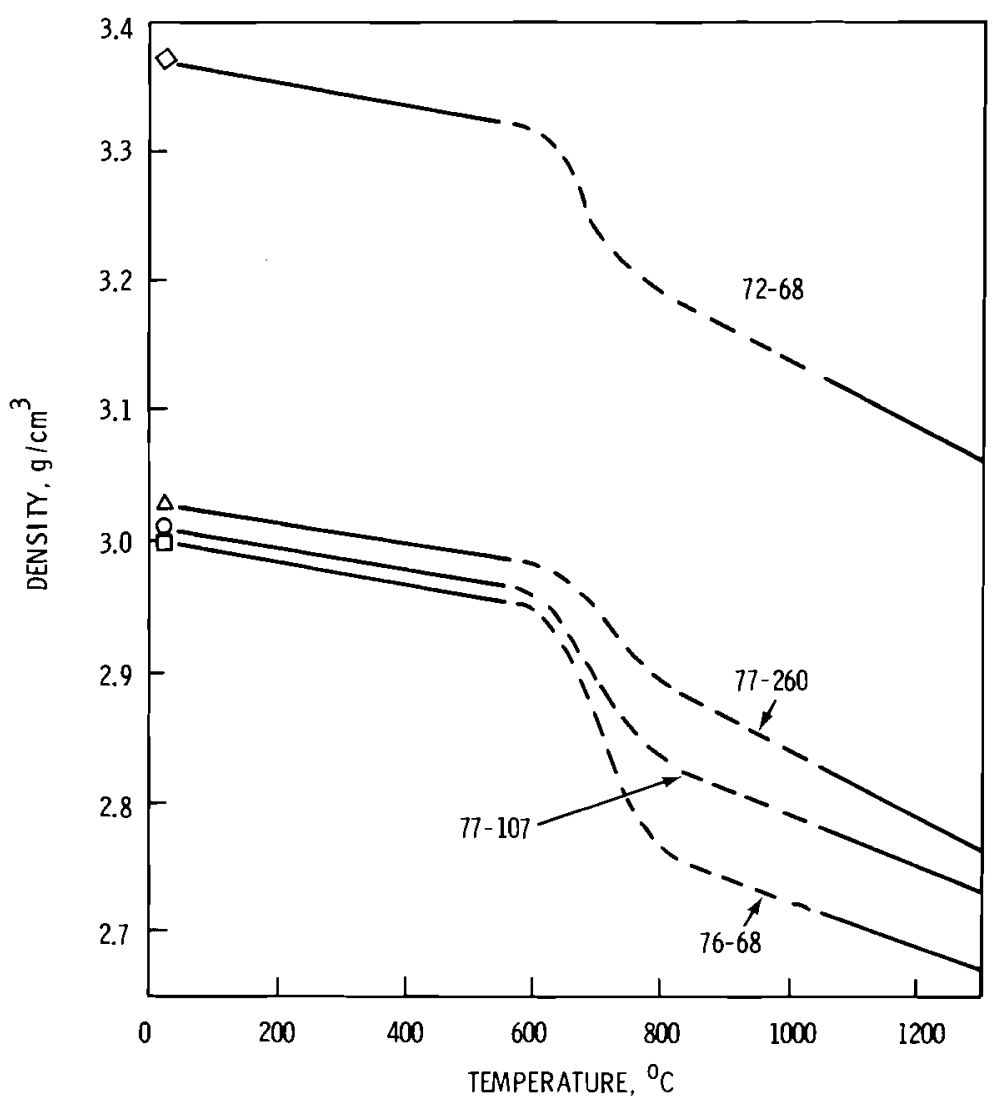

FIGURE 9. Density of Waste Glasses, Extrapolated to Lower Temperatures

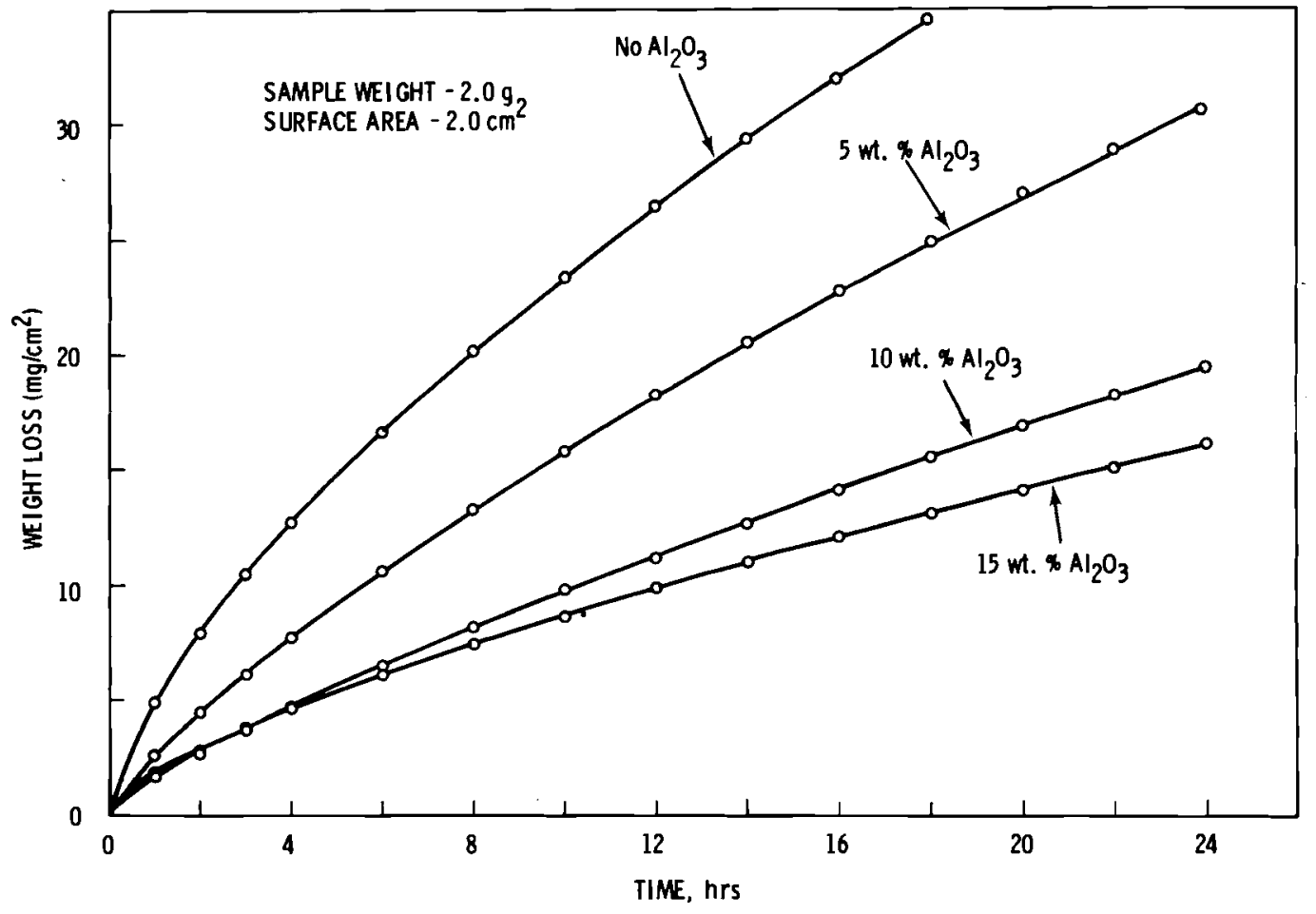

FIGURE 10. Weight Loss at $1100^{\circ} \mathrm{C}$ in Dry Air for 72-68

Glass as a Function of $\mathrm{Al}_{2} \mathrm{O}_{3}$ and Time 
2.7 with $15 \% \mathrm{Al}_{2} \mathrm{O}_{3}$, and by almost that much with $10 \% \mathrm{Al}_{2} \mathrm{O}_{3}$. If we assume that molecular complexes, such as $\mathrm{MAlSiO}_{4}$ and $\mathrm{MAlSi}_{2} \mathrm{O}_{6}$ (where $M$ represents an alkali element) are formed, then about $10.7 \mathrm{wt} \% \mathrm{Al}_{2} \mathrm{O}_{3}$ will be required to react with all the alkali elements in $72-68$ glass.

The effect of $10 \% \mathrm{Al}_{2} \mathrm{O}_{3}$ on the weight-loss of individual elements is shown in Figures 11 and 12. Relative weight loss values shown in these figures are reasonably accurate, but the absolute values overestimate losses in realistic situations for several reasons. ${ }^{(8)}$ Boron, sodium and ruthenium were hardly affected by addition of $\mathrm{Al}_{2} \mathrm{O}_{3}$, while the loss of each of the other elements was reduced by factors of two to three. These results suggest that mechanisms other than formation of alkali alumino silicates must be responsible for the reduced weight-loss rates.

Figure 13 shows gross weight-loss results at $1100^{\circ} \mathrm{C}$ for $76-183$ [PW-7a-3(2.0)76-199] glass with various amounts of $\mathrm{TiO}_{2}$ substituted for $\mathrm{SiO}_{2}$. Table 7 lists the effects on individual elements. Again, the effect on B, Na, Mo and Ru was smaller than for the other elements.

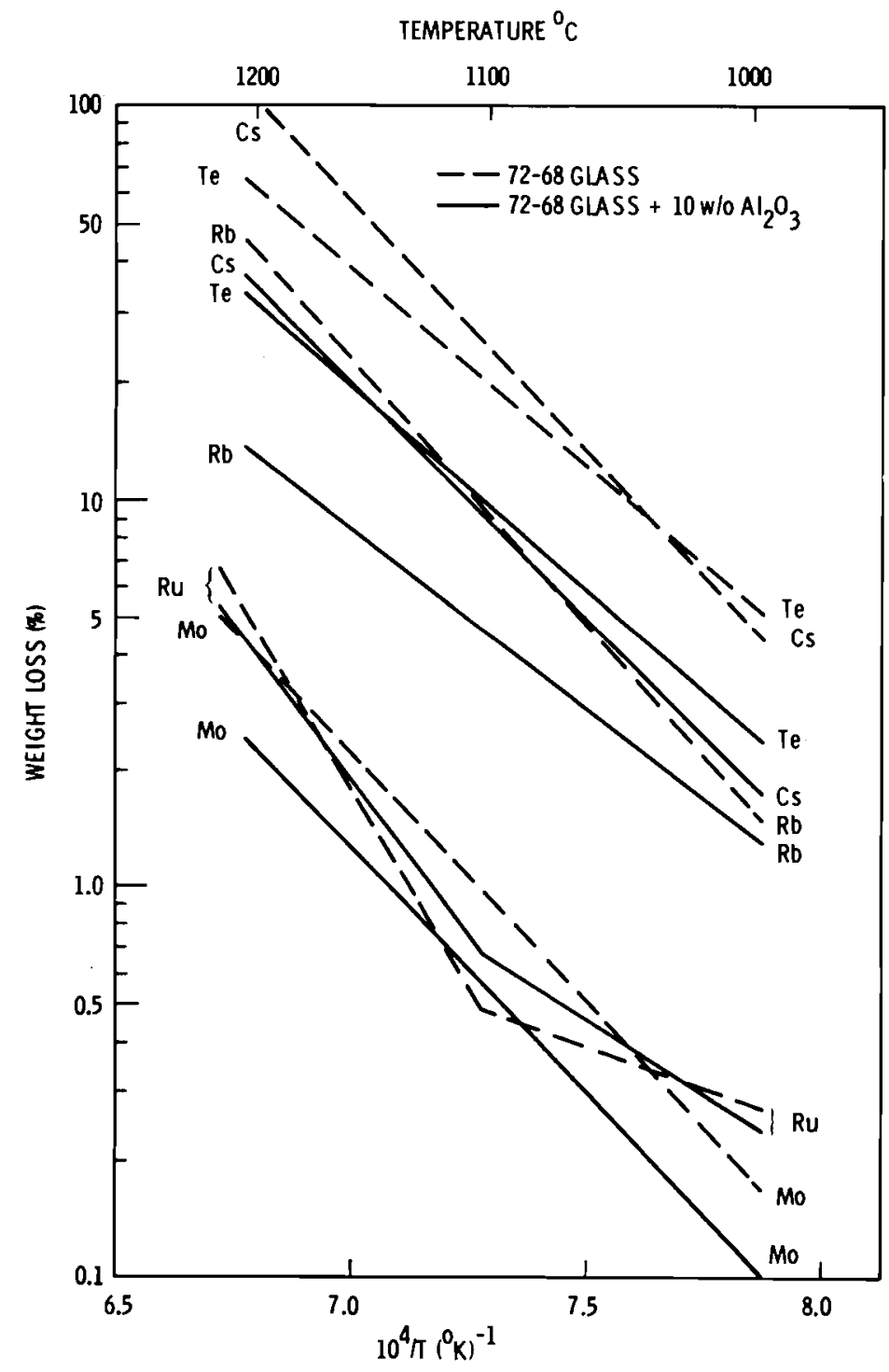

FIGURE 11. Percentage Weight Loss of Te, Mo, Cs, Rb and Ru After $4 \mathrm{Hr}$ in Dry Air 


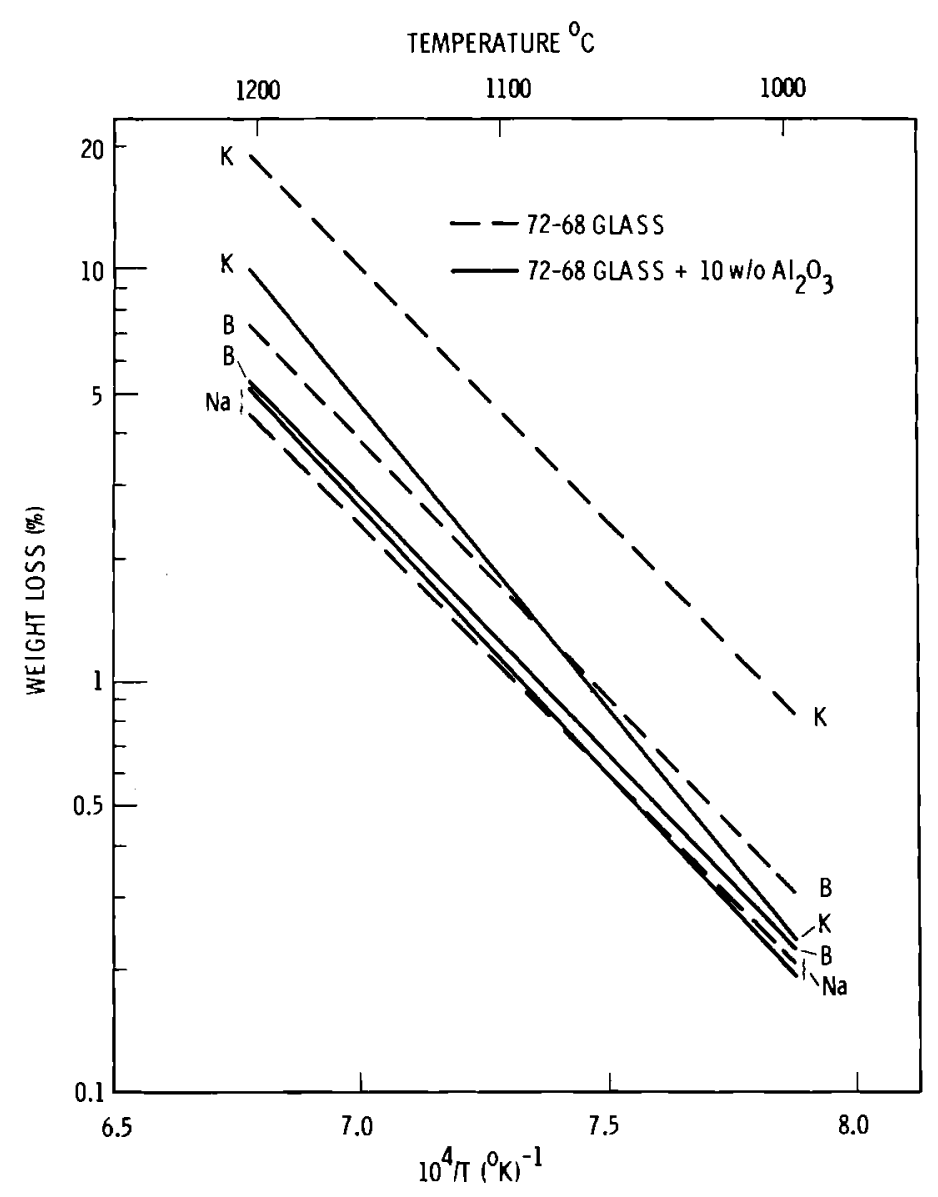

FIGURE 12. Percentage Weight Loss of $\mathrm{B}, \mathrm{K}$, and $\mathrm{Na}$ After $4 \mathrm{Hr}$ in Dry Air

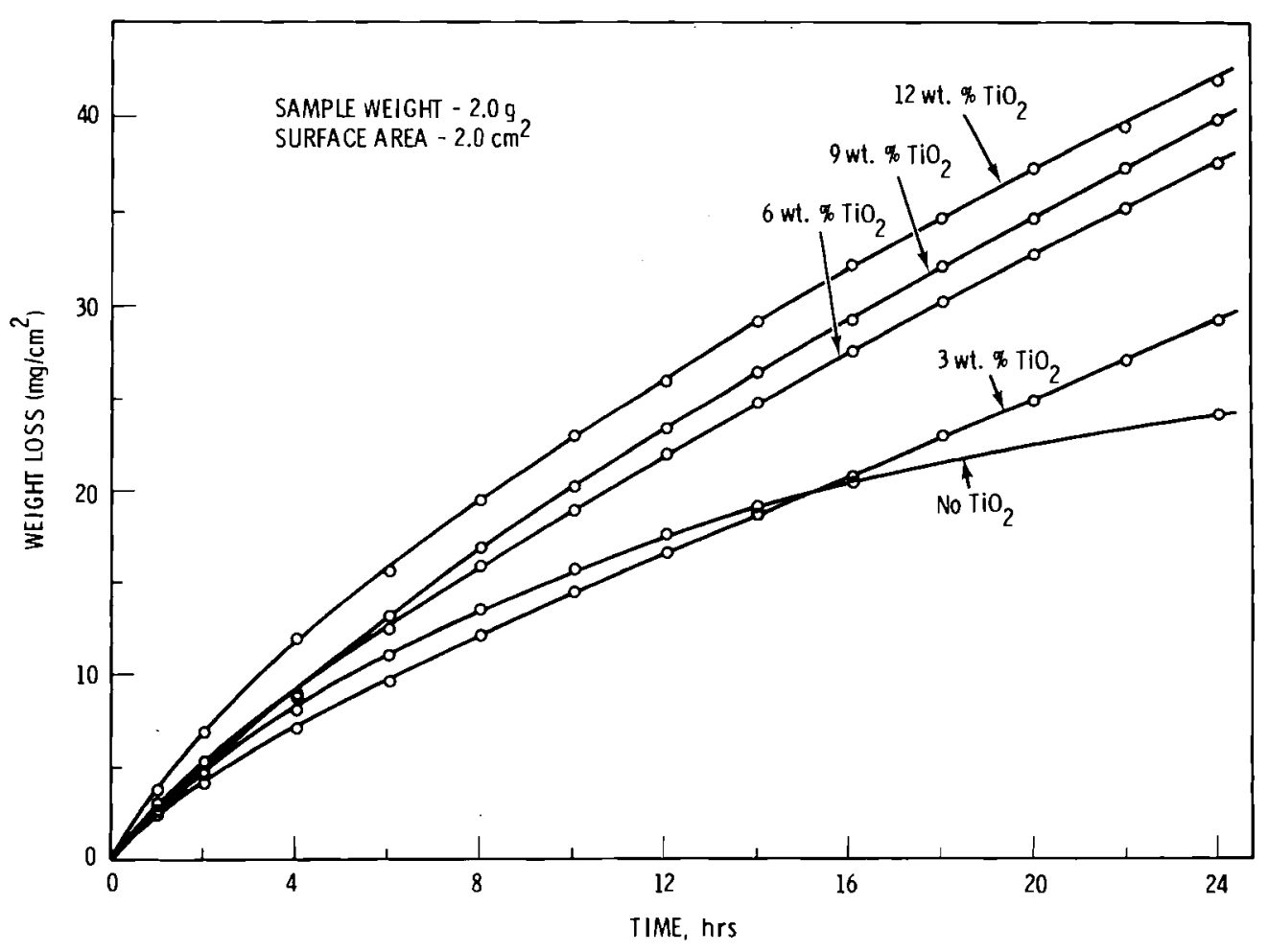

FIGURE 13. Weight Loss in Dry Air at $1100^{\circ} \mathrm{C}$ for $76-183$ Glass Containing Various Amounts of $\mathrm{TiO}_{2}$ 
TABLE 7. Percentage Weight Loss of Individual Elements from 76-183 Glass Containing Various Amounts of $\mathrm{TiO}_{2}$. Samples were heated $4 \mathrm{hr}$ at $1100^{\circ} \mathrm{C}$ in dry air.

\begin{tabular}{cccc} 
Element & \multicolumn{3}{c}{ Weight Loss (Percent) } \\
\cline { 2 - 3 } & $\frac{\text { No TiO }_{2}}{2.7}$ & $\frac{6 \mathrm{wt} \% \mathrm{Ti0}}{2.6}$ & $\frac{12 \mathrm{wt} \% \mathrm{TiO}}{2}$ \\
B & 0.6 & 0.7 & 3.3 \\
Na & 5.2 & 6.8 & 0.7 \\
K & 7.0 & 7.8 & 8.0 \\
Rb & 0.8 & 0.8 & 9.1 \\
Mo & 3.7 & 2.5 & 1.1 \\
Ru & 14.6 & 18.8 & 3.4 \\
Te & 14.6 & 18.9 & 43.6 \\
CS & & & 24.2
\end{tabular}

Both $\mathrm{Al}_{2} \mathrm{O}_{3}$ and $\mathrm{TiO}_{2}$ only modestly affected volatility. The effect on elements of dissimilar chemistry was remarkably uniform, al though at the same time Na behaved differently from the other alkali elements. This seems to suggest a mechanical rather than chemical effect on volatility. A correlation between viscosity and volatility seems likely; $\mathrm{Al}_{2} \mathrm{O}_{3}$ increases viscosity, whereas $\mathrm{TiO}_{2}$ generally decreases viscosity. This correlates with the observed effects on volatility. 


\section{ENVIRONMENTAL REACTIONS OF WASTE GLASS}

The reactions between aqueous solutions and waste glasses are primary mechanisms for release of radioactive material from the solidified waste product. We are conducting numerous experiments to determine the rate of release and to test effects of glass and solution properties on this release rate. These studies may be divided into two major areas: 1) tests with glasses prepared from nonradioactive chemicals, and 2) tests with glasses incorporating actual high-level waste.

\section{LEACHING OF NONRADIOACTIVE FISSION-PRODUCT WASTE GLASSES}

Soxhlet, acid-base, and long-term leach tests ${ }^{(2)}$ are used to measure the durability of waste glasses. The Soxhlet test uses high temperatures and distilled water to accelerate the water-glass reactions. In this report, Soxhlet test results are used to evaluate the effect of thermal storage on the glass durability. To measure glass durability in solutions spanning the $\mathrm{pH}$ range, a second acid-base test has been developed. The modified International Atomic Energy Agency (IAEA) leach test remains the long-term leach test procedure. We have discovered that the sample form and the sampling frequency affect the release rates measured in this test. Also, to determine the effects of high temperatures and pressure on glass-water reactions, we have added a test using autoclaves.

\section{Soxhlet Leach Test}

Thermal storage tests of the four standard glasses continue. During the last year, we completed one-year storage tests of $76-68[\mathrm{PW}-8 \mathrm{a}-3(1: 2) 76: 101] \mathrm{glass}$ and two-month storage tests of 77-107[PW-9-3(1:2)77-268] and 77-260[PW-7c-3(1:2)77-269] glasses. The results of Soxhlet leach tests for these samples are shown in Table 8. Neither 76-68 glass nor 77-107 glass shows any significant changes in leach rate resulting from the thermal storage. The 77-260 glass may have a slight increase in leaching after storage in the 750 to $850^{\circ} \mathrm{C}$ range for two months. For the Soxhlet test, the 72-68 glass has the lowest leach rates, the 77-107 and 77-260 have intermediate values, and the 76-68 has the highest. However, as is later discussed, the 76-68 glass shows better durability than the 72-68 glass in the long-term test.

\section{Acid-Base Leach Test}

To determine glass durabilities over the $\mathrm{pH}$ range of 1 through 13, a second acid-base test has been developed. One gram of glass crushed to $-42+60$ mesh is leached in $500 \mathrm{ml}$ of nitric acid or sodium hydroxide solutions at the selected $\mathrm{pH}$. Weight loss is measured after $72 \mathrm{hr}$ of leaching and the results are plotted as a function of $\mathrm{pH}$. Temperature is held at $25^{\circ} \mathrm{C}$.

The acid-base durability of a zinc borosilicate waste glass was determined using glass from ICM-11 [PW-7-2(1:2.6)73-1]. (9) While the calcine composition is not that of glass $72-68$, the results shown in Figure 14 for ICM-11 are representative of the durability of waste glasses made with the zinc-borosilicate frit 73-1. The data indicate that the glass is quite leachable in $\mathrm{pH}$ solutions below 3 . Excellent durability is shown by 76-68, 77-107, and 77-260 glasses even in the lower $\mathrm{pH}$ solutions. 
TABLE 8. Standard Glasses Soxhlet Leach Data After Thermal Storage ${ }^{(a)}$

\begin{tabular}{c} 
Storage \\
Temperature \\
${ }^{\circ} \mathrm{C}$ \\
\hline 1200 \\
1150 \\
1100 \\
1050 \\
1000 \\
900 \\
850 \\
800 \\
750 \\
700 \\
650 \\
600 \\
550 \\
500 \\
400 \\
300
\end{tabular}

\begin{tabular}{lrrrrr}
\multicolumn{6}{c}{ Glass $76-68$} \\
\cline { 1 - 2 } 5.40 & & & & \\
& & & & \\
3.90 & & & & \\
5.80 & & & & \\
5.30 & & & & \\
& 5.02 & 8.41 & 7.50 & 7.45 \\
& 3.92 & 4.03 & 4.60 & 8.00 \\
4.90 & 5.72 & 5.80 & 9.40 \\
& 7.09 & 7.70 & 8.60 & 8.00 \\
4.05 & 5.00 & 6.50 & 5.61 \\
& 7.47 & 3.73 & 11.70 & 3.70 \\
7.97 & 8.70 & 5.80 & 4.90 \\
4.20 & 6.80 & 6.60 & 5.66 \\
4.54 & 6.20 & 11.20 & 7.20 \\
& & 6.50 & 1.80 \\
& & & 6.80 & 4.90
\end{tabular}

\begin{tabular}{llll}
\multicolumn{5}{c}{ Glass } & $77-107$ \\
\hline$\frac{2 \mathrm{Hr}}{2.48}$ & $\underline{1 \mathrm{Da}}$ & $\underline{1 \mathrm{Wk}}$ & $\underline{2 \mathrm{Mo}}$ \\
3.13 & & & \\
3.73 & & & \\
2.18 & & & \\
3.13 & & & \\
& 2.72 & 1.86 & 1.85 \\
& 2.00 & 3.51 & 2.29 \\
& 2.53 & 2.34 & 1.90 \\
2.56 & 2.53 & 2.05 \\
2.45 & 2.00 & 3.31 \\
2.28 & 2.81 & 2.03 \\
3.60 & 1.66 & 2.16 \\
1.60 & 3.15 & 3.50 \\
2.97 & 2.50 & 1.63 \\
& & 2.56 \\
& & 2.31
\end{tabular}

\begin{tabular}{llll}
\multicolumn{5}{c}{ Glass } & $77-260$ \\
\cline { 1 - 1 }$\frac{2 \mathrm{Hr}}{2.14}$ & $\underline{1 \mathrm{Da}}$ & $\underline{1 \mathrm{Wk}}$ & $\underline{2 M 0}$ \\
3.10 & & & \\
3.22 & & & \\
3.47 & & & \\
3.80 & & & \\
& 4.19 & 2.53 & 4.40 \\
& 2.68 & 6.60 & 5.00 \\
& 3.30 & 5.50 & 7.30 \\
& 2.89 & 4.71 & 5.70 \\
5.13 & 6.88 & 3.00 \\
3.46 & 3.03 & 2.70 \\
3.26 & 2.31 & 3.20 \\
2.10 & 5.33 & 2.40 \\
2.60 & 4.25 & 1.90 \\
& & 4.10 \\
& & 3.60
\end{tabular}

(a) Leach rate in $\%$ weight loss in 72 hours. Convert to $\mathrm{g} / \mathrm{cm}^{2}$ day by multiplying by $1.28 \times 10^{-5}$.

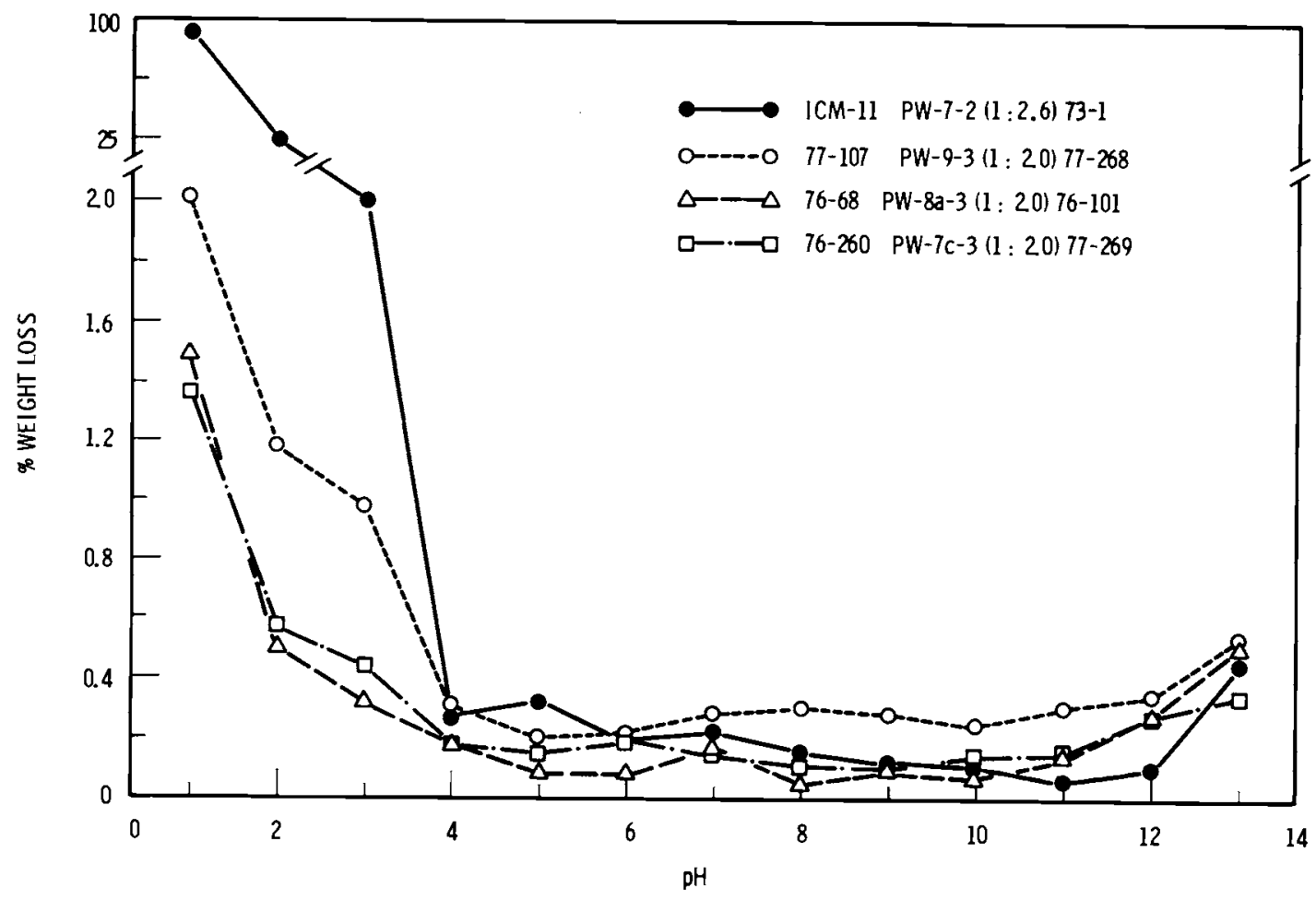

FIGURE 14. Acid-Base Durability of Waste Glasses 
The apparent acid durability of the zinc borosilicate waste glass depends on the acid used in the test. As Figure 15 illustrates, pH 4 solutions prepared with strong acids attack the waste glass less than solutions prepared with weak acids or buffers. It appears, therefore, that the total hydrogen available, rather than the $\mathrm{pH}$, is a determining factor in glass durability.

Long-Term Leach Test

The four standard waste glasses are being subjected to the modified IAEA leach test. In long-term leach rates of samples generated in the Thermal Effects studies, data indicate that the sampling period and the physical form of the sample may affect the calculated leach rates.

To date, we have leach-rate data for 72-68 [PW-4b-6(1:2.8)73-1] through 624 days of leaching. Glass leach rates based on cesium, strontium, and uranium are shown in Figure 16. The release rates are decreasing slowly with time, although the decrease may be influenced by the sampling period.

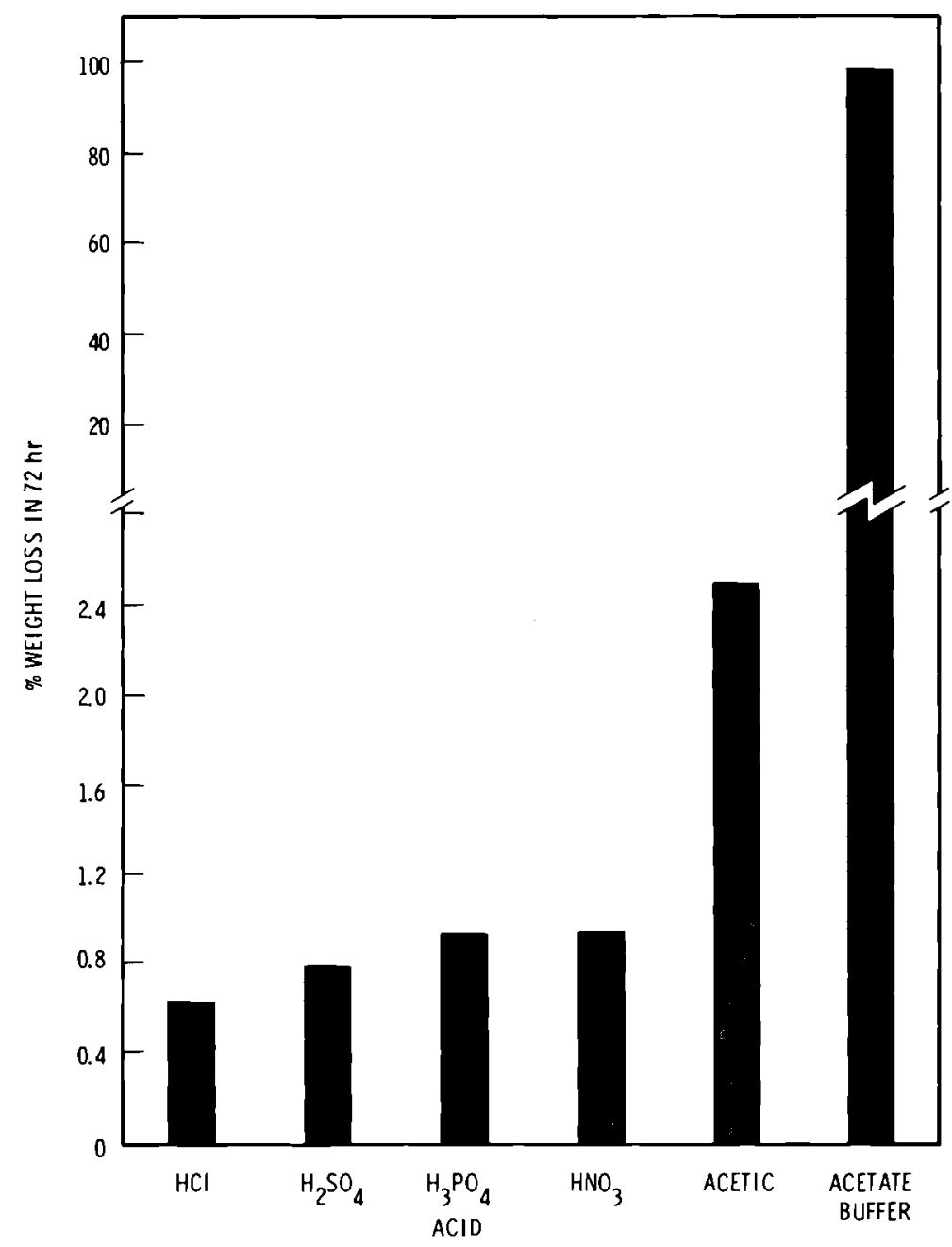

FIGURE 15. Influence of Acid Type on Durability of ICM-11 Glass in $\mathrm{pH} 4$ Solutions 


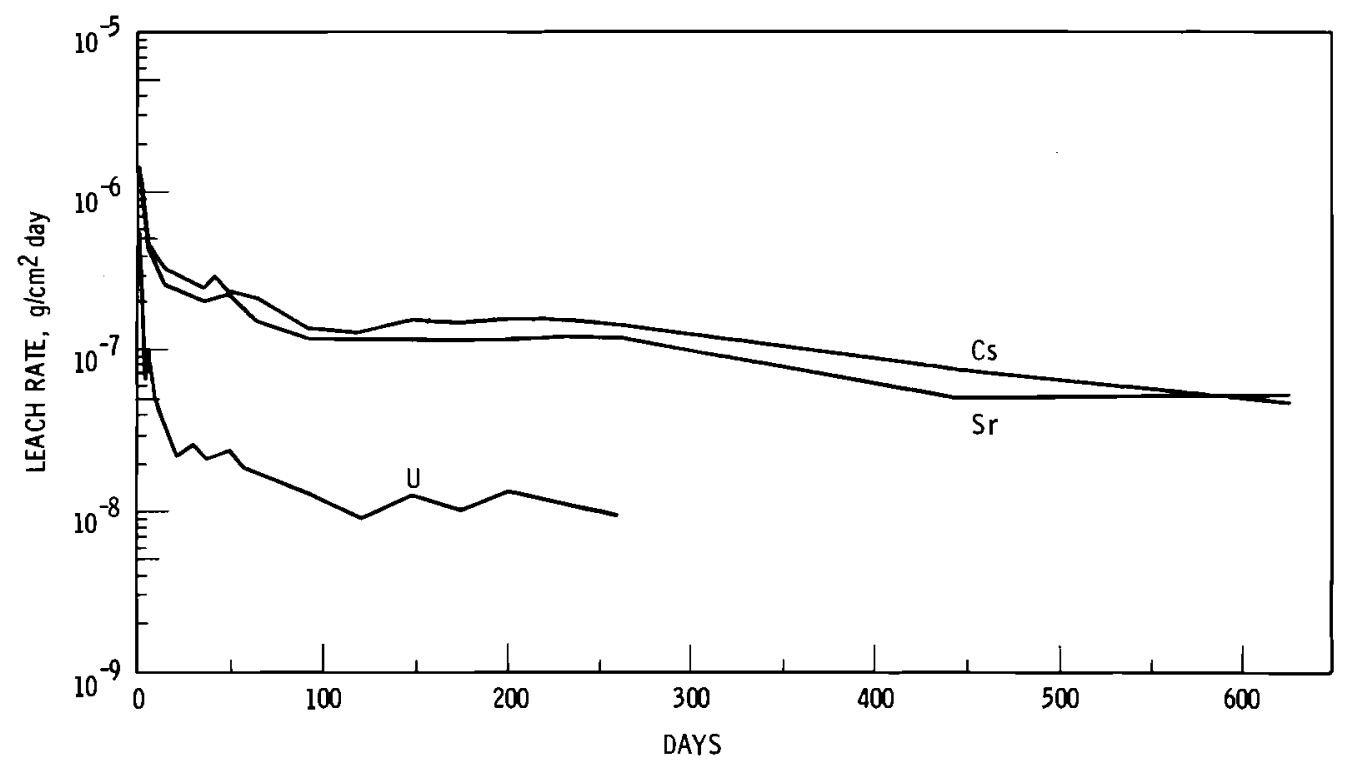

FIGURE 16. Long-Term Leach Rates Based on $\mathrm{Cs}, \mathrm{Sr}$, and $U$ for $72-68$ Glass

In addition to cesium, strontium, and uranium, long-term leach rates based on barium, molybdenum, zinc and zirconium have been determined for vitreous $\left(1000^{\circ} \mathrm{C} 2 \mathrm{hr}\right)$ and devitrified $\left(700^{\circ} \mathrm{C} 2 \mathrm{mo}\right)$ samples of $72-68 \mathrm{glass}$. Table 9 lists average leach rates from 28 through 259 days for the elements analyzed. Devitrification caused significant increases in leach rates based on $\mathrm{Cs}, \mathrm{Sr}$, and $\mathrm{U}$. The large decrease in the zinc-based leach rates may be related to the formation of $\mathrm{Zn}_{2} \mathrm{SiO}_{4}$ in the devitrified product.

While the 76-68 glass leaches faster than the reference glass in the Soxhlet leach test, the 76-68 glass shows a lower leach rate in the long-term test, illustrated in Figure 17. Average long-term leach rates from 28 through 175 days of leaching are plotted as a function of the two-month annealing temperature for the reference glass $72-68$ [PW-4b-6(1:2.8)73-1], and glass 76-68 [PW-8a-3(1:2)76-101]. The release rates based on cesium indicate: 1) the lower long-term leach rates of the 76-68 glass compared with the reference glass, and 2) the relative insensitivity of the $76-68 \mathrm{glass}$ durability to thermal treatment. The average leach rate of the as-melted glass $\left(1050^{\circ} \mathrm{C} 2 \mathrm{hr}\right)$ is $3.3 \times 10^{-8} \mathrm{~g} / \mathrm{cm}^{2}$-day.

TABLE 9. Average Long-Term Leach Rates of $72-68$ $[\mathrm{PW}-4 \mathrm{~b}-6(2.8) 73-1] \mathrm{G} 1 \mathrm{ass}\left(\mathrm{g} / \mathrm{cm}^{2}-\right.$ day $)$

\begin{tabular}{ccc}
$\begin{array}{c}\text { Element } \\
\text { Analyzed }\end{array}$ & $\begin{array}{c}\text { Vitreous } \\
1000^{\circ} \mathrm{C} 2 \text { Hours }\end{array}$ & $\begin{array}{c}\text { Devitrified } \\
\text { Ba }\end{array}$ \\
\cline { 1 - 3 } & $2.18 \times 10^{-6}$ & $\frac{700^{\circ} \mathrm{C} 2 \text { Months }}{1.53 \times 10^{-6}}$ \\
$\mathrm{Cs}$ & $1.82 \times 10^{-7}$ & $2.43 \times 10^{-6}$ \\
Mo & $1.01 \times 10^{-6}$ & $1.28 \times 10^{-6}$ \\
$\mathrm{Sr}$ & $1.52 \times 10^{-7}$ & $1.12 \times 10^{-6}$ \\
$\mathrm{U}$ & $1.60 \times 10^{-8}$ & $6.86 \times 10^{-8}$ \\
$\mathrm{Zn}$ & $1.29 \times 10^{-6}$ & $8.17 \times 10^{-9}$ \\
$\mathrm{Zr}$ & $2.00 \times 10^{-6}$ & $4.95 \times 10^{-7}$
\end{tabular}




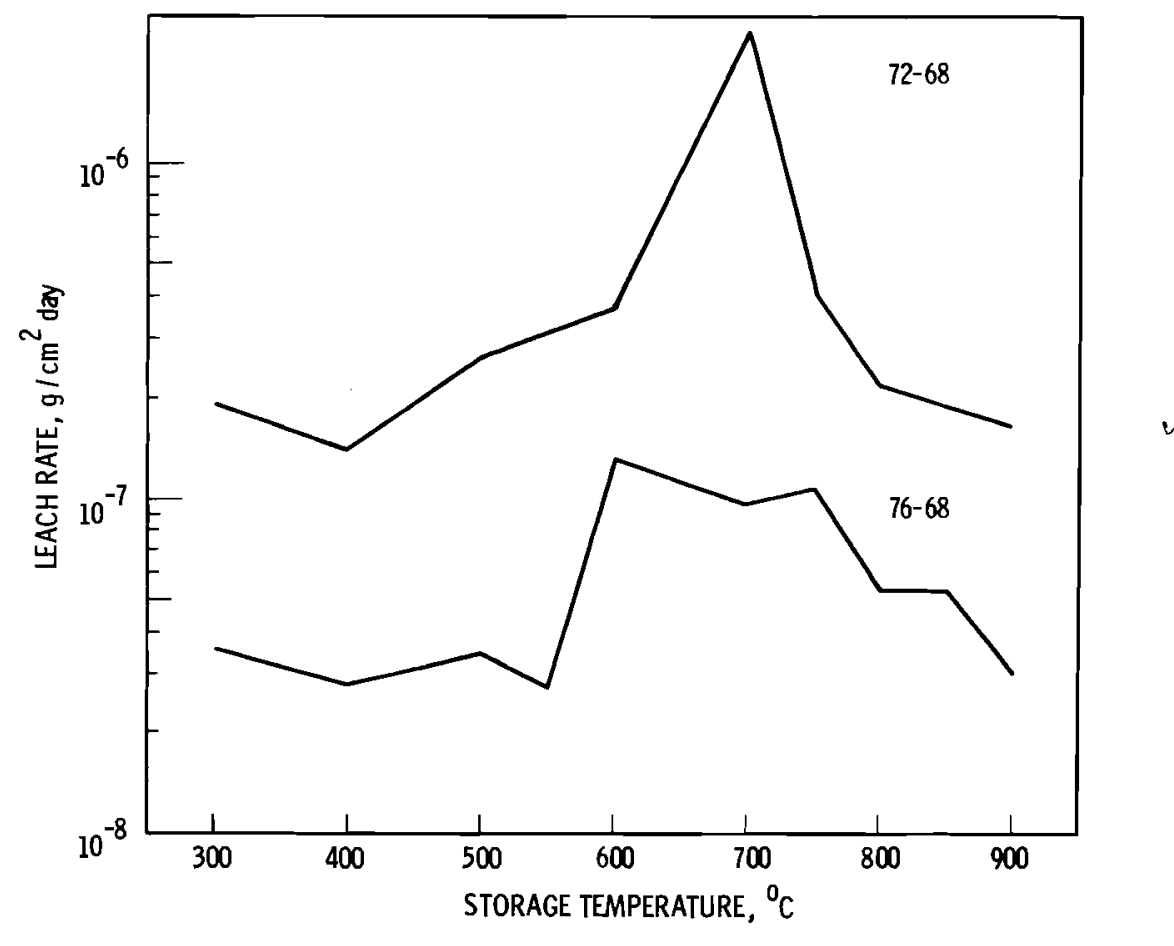

FIGURE 17. A Comparison of Devitrification Effects on Leaching of 72-68 and 76-68 Glass

Leach rates of $76-68[\mathrm{PW}-8 \mathrm{a}-3(1: 2) 76-101]$ glass based on cesium and strontium are plotted in Figures 18 and 19. The curves in each figure represent the leach rates of the as-melted glass and of the Thermal Effect Studies sample with the highest crystallinity, which is the 2-month sample stored at $750^{\circ} \mathrm{C}$ (see Phase Behavior). After an initial rapid decrease in the leach rate, the glass release rate is remaining relatively constant. The increased crystallinity causes a small increase in the leach rate of the glass.

In the long-term leach test, the sampling period increases from daily to weekly to monthly and, finally, to semiannually. Figure 20 indicates that especially for the long leach periods, the buildup of ions in the leachant may reduce the leach rate of the glass. In this figure, cumulative penetration based on cesium is plotted as a function of time for $-42+60$ mesh samples of $72-68$ [PW-4b-6(1:2.8)73-1] glass. Two samples were leached: 1) the leachant was changed in accordance with the IAEA test sampling schedule, and 2) the leachant was not removed. After about 30 days, the cumulative penetration curves for the two samples began to separate, with only a slight increase in penetration beyond 150 days for the static system. Therefore, the monthly and semiannual sampling times in the IAEA procedures may cause slight decreases in the calculated glass leach rates.

We have observed that solid pieces exhibit higher calculated release rates than $-42+60$ mesh powder of the same glass. Figure 21 illustrates this effect for the 76-68 [PW-8a-3(1:2)76-101] glass. We noted similar results for the reference glass. Two factors probably contribute to the difference. First, geometric surface areas are used to calculate powdered glass leach rates. Because of surface roughness, the geometric surface area is low, yielding a higher 


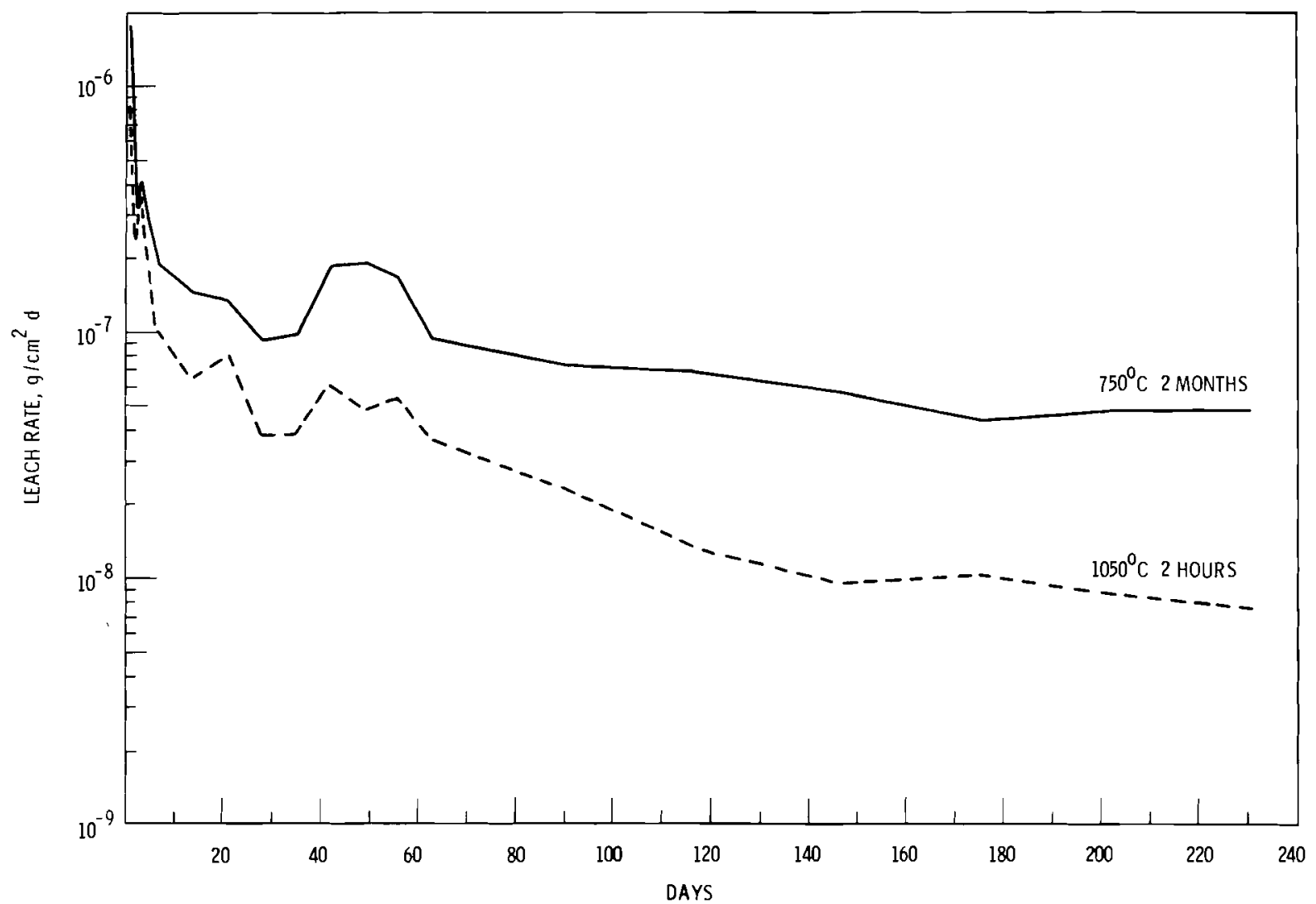

FIGURE 18. Long-Term Leach Rates Based on CS for 76-68 Glass

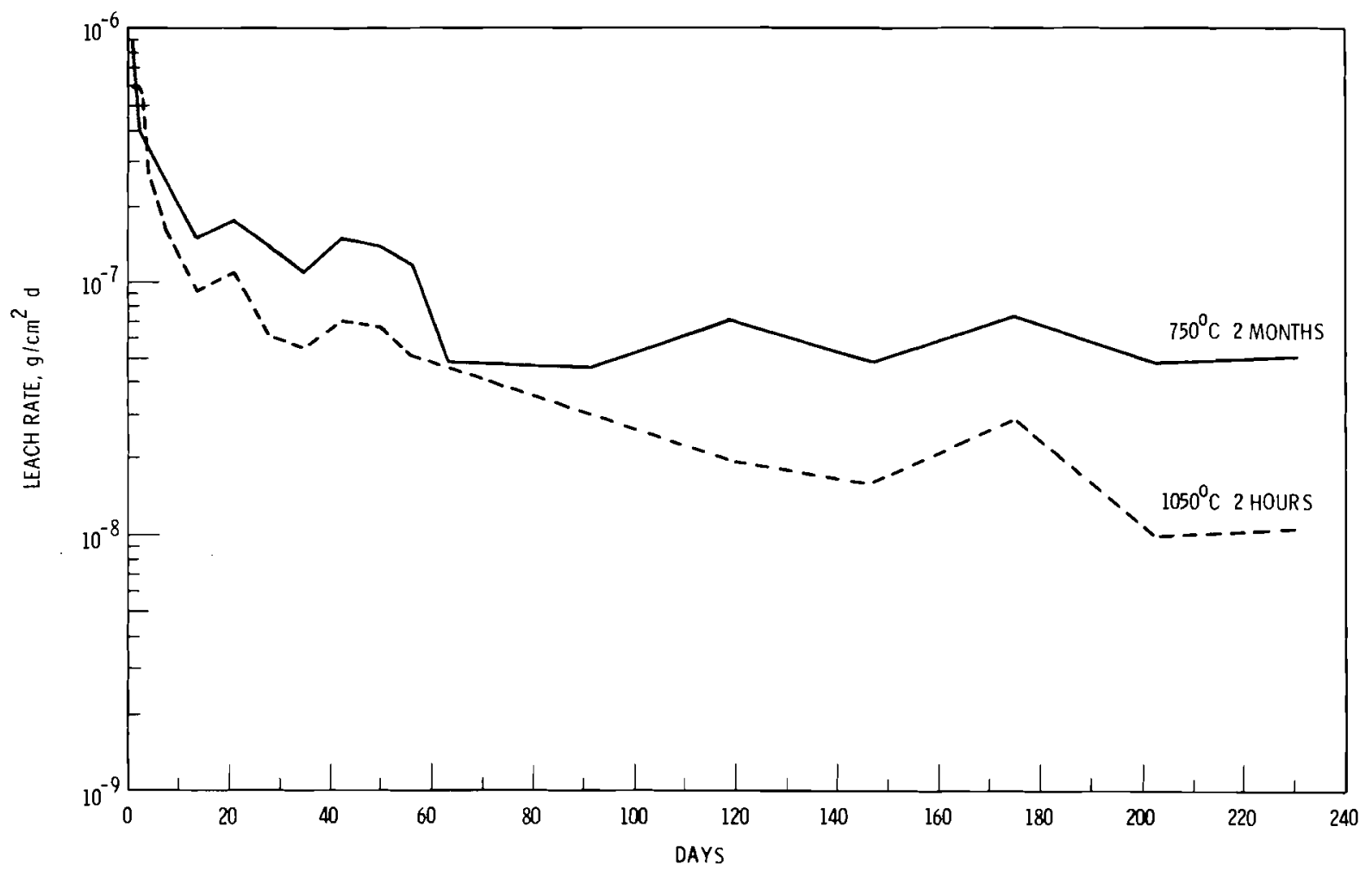

FIGURE 19. Long-Term Leach Rates Based on Sr for 76-68 Glass 
FIGURE 20. A Comparison of Stagnant Versus Dynamic Leach Test Results
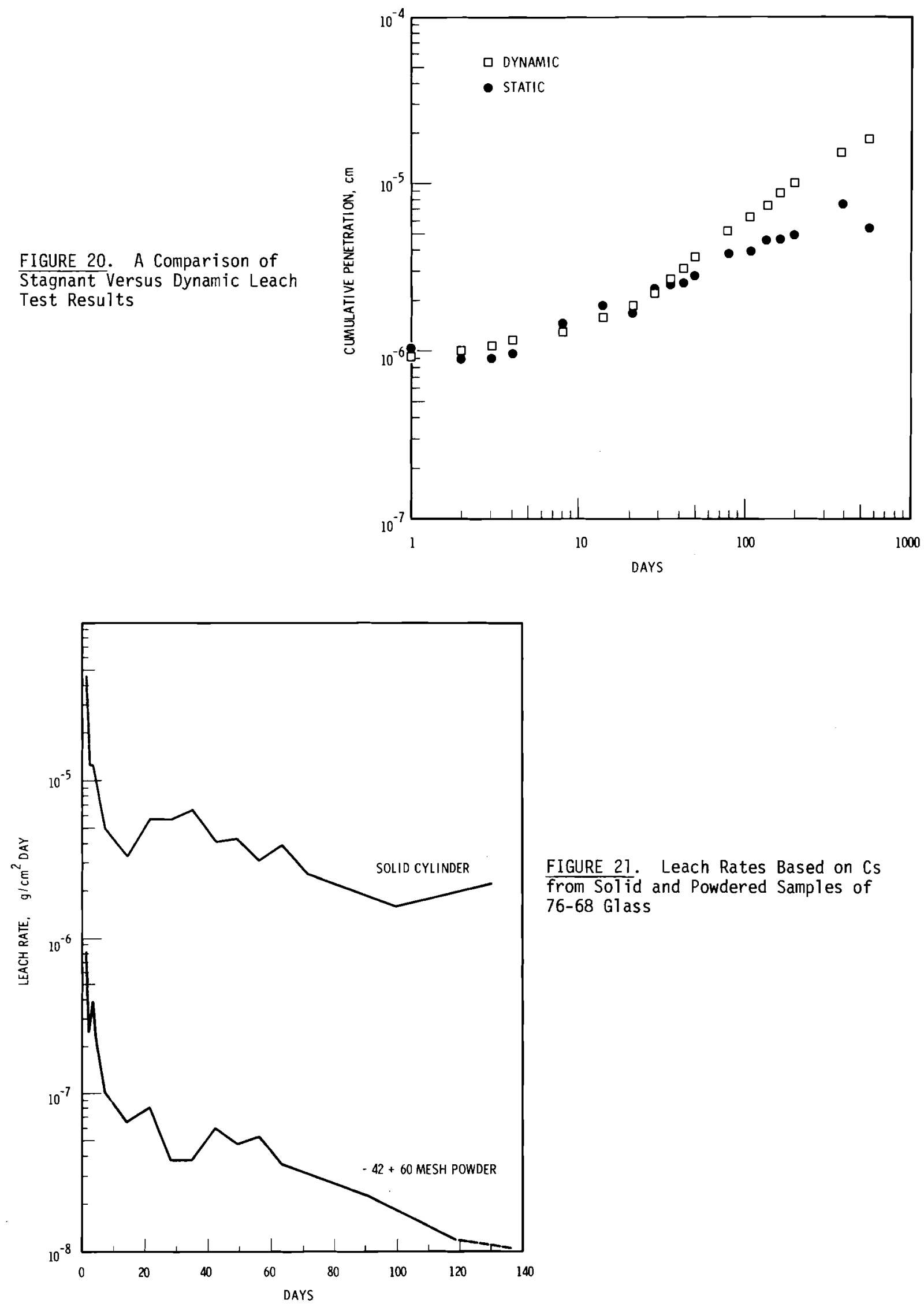

FIGURE 21. Leach Rates Based on CS from Solid and Powdered Samples of 76-68 Glass 
leach rate. Second, the interstitial areas between the glass particles probably have higher concentrations of the leached ions than the bulk solution, resulting in reduced leaching from particles exposed only to the interstitial fluid. The net effect is to reduce the apparent leach rate of the powdered glass.

High-Temperature and High-Pressure Tests

Our first high-temperature experiments were designed to generate relative numbers for the durability of several waste related materials. The leach rates based on weight loss of canister materials, glasses, and ceramics exposed to $80 \%$ saturated salt brine at $250^{\circ} \mathrm{C}$ and 1000 psi for $72 \mathrm{hr}$ are listed in Table 10. The data reveal that the three metals have the highest apparent durability. Within experimental error, the two simulated HLW glasses and the nonirradiated pellet are at least as durable as the borosilicate glass in the salt solution. The results listed in this table also show that increasing the solution yolume while holding the amount of glass constant increases the weight loss rate of the glass. Deionized water represents a "worst" case relative to the salt solution. The $76-68$ glass lost more weight in deionized water than in salt brine.

Our experiments at $250^{\circ} \mathrm{C}$ also yield leach rate-versus-time data. Figure 22 shows weight loss data for $76-68$ glass in $50 \mathrm{ml}$ of $80 \%$ saturated brine at $250^{\circ} \mathrm{C}$. For these conditions no further weight loss was observed after one week of contact. However, the figure also shows that in $125 \mathrm{ml}$ of $100 \%$ saturated brine at $350^{\circ} \mathrm{C}$ the weight loss continues to increase after three weeks.

TABLE 10. Scouting Autoclave Leach Test Results ${ }^{(a)}$

\begin{tabular}{|c|c|c|c|}
\hline \multirow[b]{2}{*}{ Sample Material } & \multicolumn{3}{|c|}{ Leach Rate, Grams $/ \mathrm{cm}^{2}-$ day $(\mathrm{b})$} \\
\hline & $\begin{array}{c}50 \mathrm{ml} \\
\text { Brine Solution }\end{array}$ & $\begin{array}{c}150 \mathrm{ml} \\
\text { Brine Solution }\end{array}$ & $\begin{array}{c}50 \mathrm{ml} \\
\text { Deionized Water }\end{array}$ \\
\hline Soda-lime-silica glass (NBS No. 710) & $3.1 \times 10^{-3}$ & & \\
\hline Borosilicate glass (NBS No. 717) & $5.2 \times 10^{-4}$ & & \\
\hline Waste glass $72-68[\mathrm{PH}-4 \mathrm{~b}-7(2.8) 73-1]$ & $7.2 \times 10^{-4}$ & & \\
\hline Waste glass $76-68[\mathrm{PW}-8 \mathrm{a}-3(2.0) 76-101]$ & $1.6 \times 10^{-4}$ & $1.8 \times 10^{-3}$ & $7.9 \times 10^{-3}$ \\
\hline Granite & $6.4 \times 10^{-4}$ & & \\
\hline $\mathrm{UO}_{2}$ fuel pellet & $1.5 \times 10^{-4}$ & & \\
\hline Alumina & $1.5 \times 10^{-4}$ & & \\
\hline Pelletized super calcine (SPC-2) & $4.2 \times 10^{-4}$ & & \\
\hline 304L stainless stee 1 & $4.1 \times 10^{-5}$ & & \\
\hline Incone1 601 & $4.2 \times 10^{-5}$ & & \\
\hline Carbon steel & $7.4 \times 10^{-5}$ & & \\
\hline
\end{tabular}

(a) 72 hours at $250^{\circ} \mathrm{C}$ and 1000 psi.

(b) Based on weight loss and geometric surface area. 


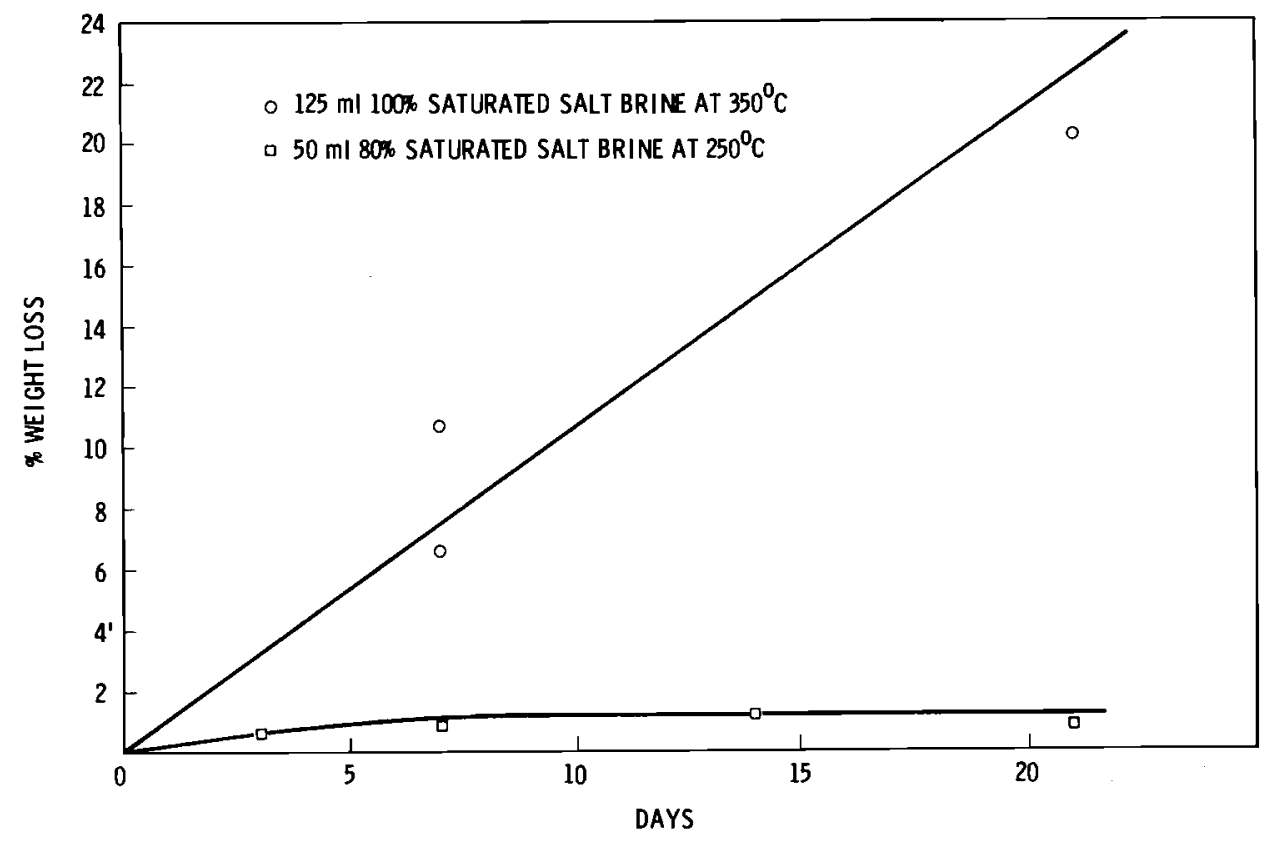

FIGURE 22. Durability of 76-68 Glass as a Function of Time Under High Temperature Pressure Conditions

After these scouting tests, we began testing 76-68 [PW-8a-3(1:2.0)76-101] glass to study in detail the hydrothermal glass reactions. Both powdered glass and a solid core were heated in $350^{\circ} \mathrm{C}$ deionized water for one week. Powdered salt and -100 mesh 304 stainless steel were added to the system to define their effect on the reaction products. The ratio of glass to salt to water was $1: 10: 12.5$. Table 11 lists the weight loss leach rates of the glass cores from the first three tests.

Metallographic examination of the three cores revealed that the two treated in salt brine developed a reaction zone $0.7-\mathrm{mm}$ thick. The core treated in deionized water with no salt reacted through its entire $13-\mathrm{mm}$ diameter.

From these data we conclude that the canister material does not affect the hydrothermal reaction. However, salt appears to inhibit the rate of reaction, as evidenced by the smaller reaction layer. Both X-ray fluorescense and SEM with energy-dispersive X-ray fluorescense analyses of the surface show large depletions of $C s, R b$ and Mo from the surface of the cores. $X$-ray diffraction of the powdered glass identified $\mathrm{NaFeSi}_{2}{ }_{6}$ as the major hydrothermal reaction product. Several other places remain to be identified.

TABLE 11. Hydrothermal Glass Reaction Results
Test 2
glass + salt + steel + water
$4.0 \times 10^{-3} \mathrm{~g} / \mathrm{cm}^{2}$ day
Test 3
glass + salt + water
$4.7 \times 10^{-3} \mathrm{~g} / \mathrm{cm}^{2}$ day
Test 4
glass + water
$5.3 \times 10^{-3} \mathrm{~g} / \mathrm{cm}^{2}$ day 


\section{LEACHING OF FULLY RADIOACTIVE WASTE GLASSES}

To be fully confident in our analyses of waste glass behavior, the measurements on simulated waste glasses must be substantiated by measurements on fully radioactive glasses prepared from actual HLLW. High-level liquid waste from commercial LWR fuel is not yet available, so it must be prepared in the laboratory. After the HLLW is prepared, it is batch calcined, combined with glass frit, and melted. Presently, we are storing and testing specimens of this full-level radioactive glass.

The leach tests reported last year ${ }^{(2)}$ have been continued and to date, a total of 639 days of leach testing have been completed. The procedures are basically unchanged. The leachates are currently being analyzed at six-month intervals, and data has been recorded on four sections of a mini-canister $(\sim 80 \mathrm{~g})$. Major differences for the sections were not noted, except possibly for $\mathrm{Pu}$, which had a 2 to 3 times higher release rate from the middle section than from the top or bottom.

Figures 23 and 24 show the leach rates with time for all isotopes found in the top section of waste glass. The other layers followed suit with the top layer to yield the following order of leaching from the waste glass:

$$
\mathrm{Cs}>\mathrm{Sr}>\mathrm{Co}>\mathrm{Sb}>\mathrm{Mn}>\mathrm{Pu}>\mathrm{Eu}>\mathrm{Cm}>\mathrm{Ce}
$$

This order, spanning four orders of magnitude, is more easily seen in Figure 25, which plots the cumulative leach fraction as a function of time for the bottom section of waste glass. The slopes of the lines seem to change as a function of time and sampling frequency. To illustrate this, the slopes for each isotope were calculated from Figure 25 (and from a similar plot for the top layer) for periods corresponding to the start of the test and changes in sampling frequency. These slopes are tabulated in Table 12. At the beginning of the test, leaching is a diffusion process, with the slope nearly 0.5 . This changes to a combined diffusion/corrosion process within two weeks, denoted by the slope nearing 0.75. The effect of sampling frequency can be readily seen in the period between 240 and 639 days, corresponding to a sampling time change from monthly to semi-annually. The change from weekly to monthly sampling times appears to have had little effect except for extending the time needed to approach a slope of one. The time from 100 to 240 days is a long period of monthly sampling without interruption and shows a corrosion controlled leaching mechanism, as seen by the slope of nearly one.

When we correlate the leach rates of fully-radioactive glass sections with leach rates of a simulated waste glass, we find that the leach rates for $\mathrm{Cs}$ and $\mathrm{Sr}$ are the same. For 72-68 glass, the leach rates of CS and $\mathrm{Sr}$ from fully radioactive and simulated glass are 2 $\times 10^{-5} \mathrm{~g} / \mathrm{cm}^{2}$-day. An experiment is planned to compare simulated versus fully radioactive leach rates for four different waste glasses. (The phase characterization of these glasses is discussed in the following section, Phase Behavior.) 


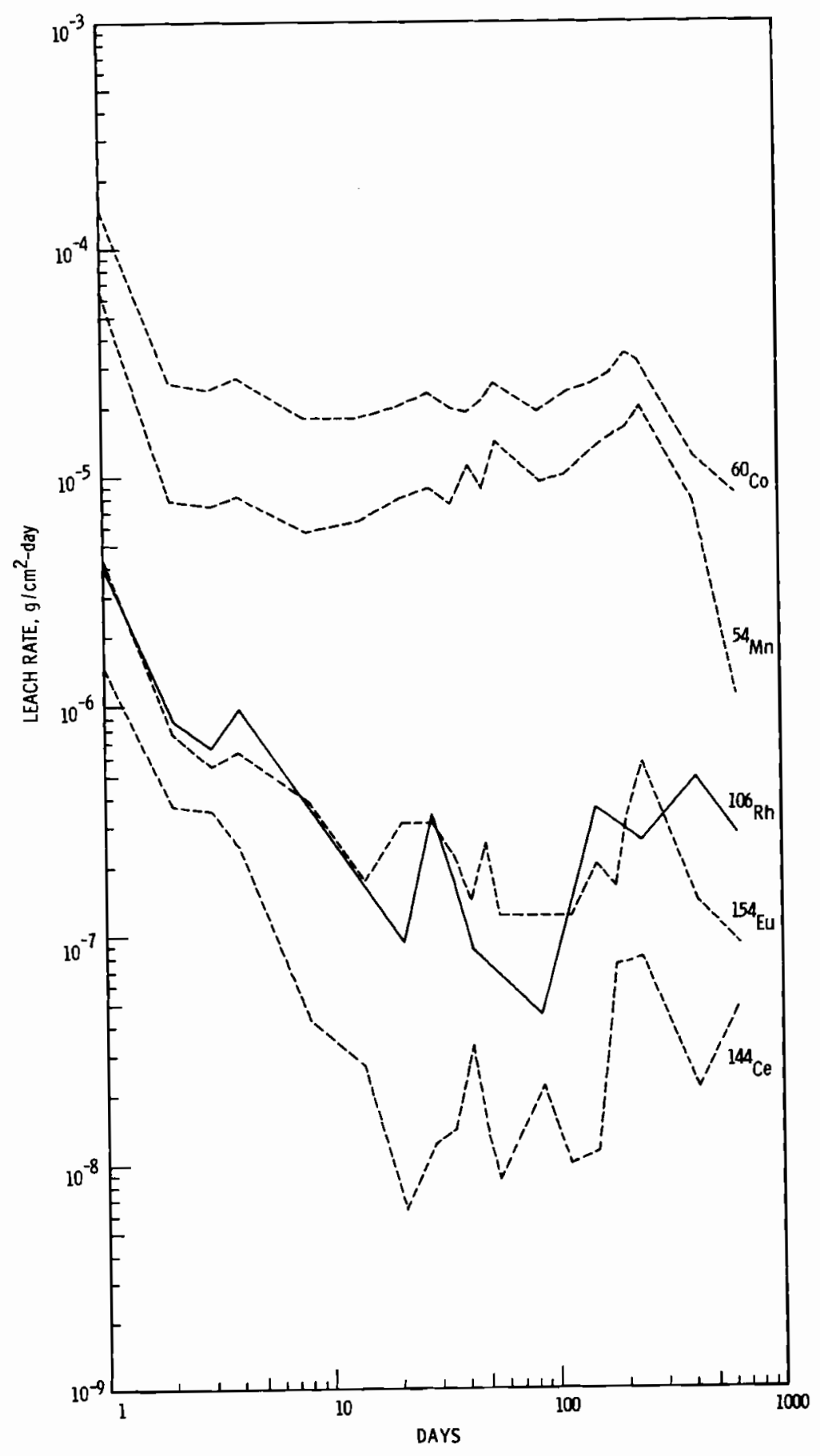

FIGURE 23. Leach Rate as a Function of Time for Co, Mn, Rh, Eu, and Ce 


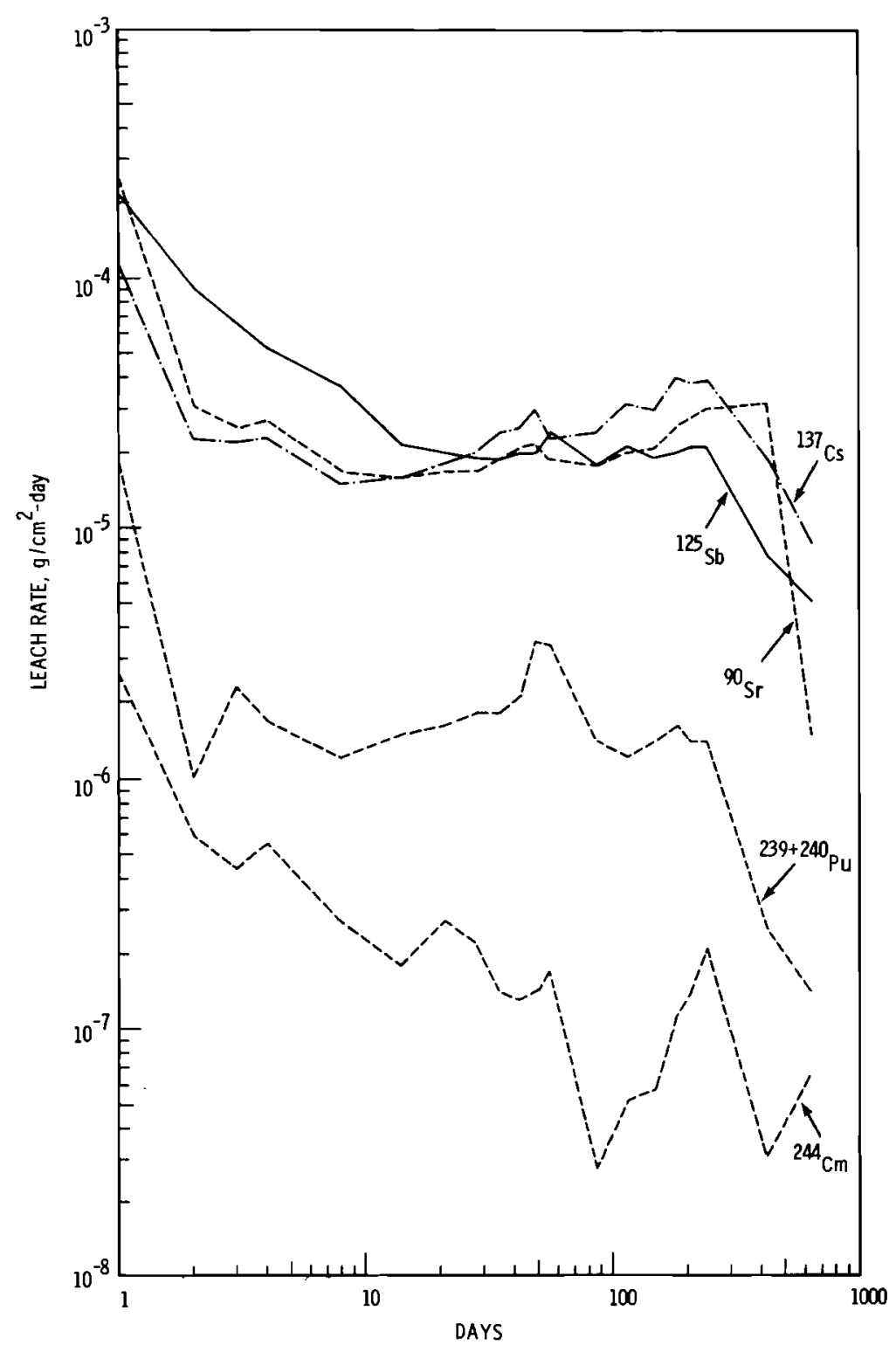

FIGURE 24. Leach Rate as a Function of Time for $\mathrm{Cs}, \mathrm{Sb}, \mathrm{Sr}, \mathrm{Pu}$, and $\mathrm{Cm}$ 


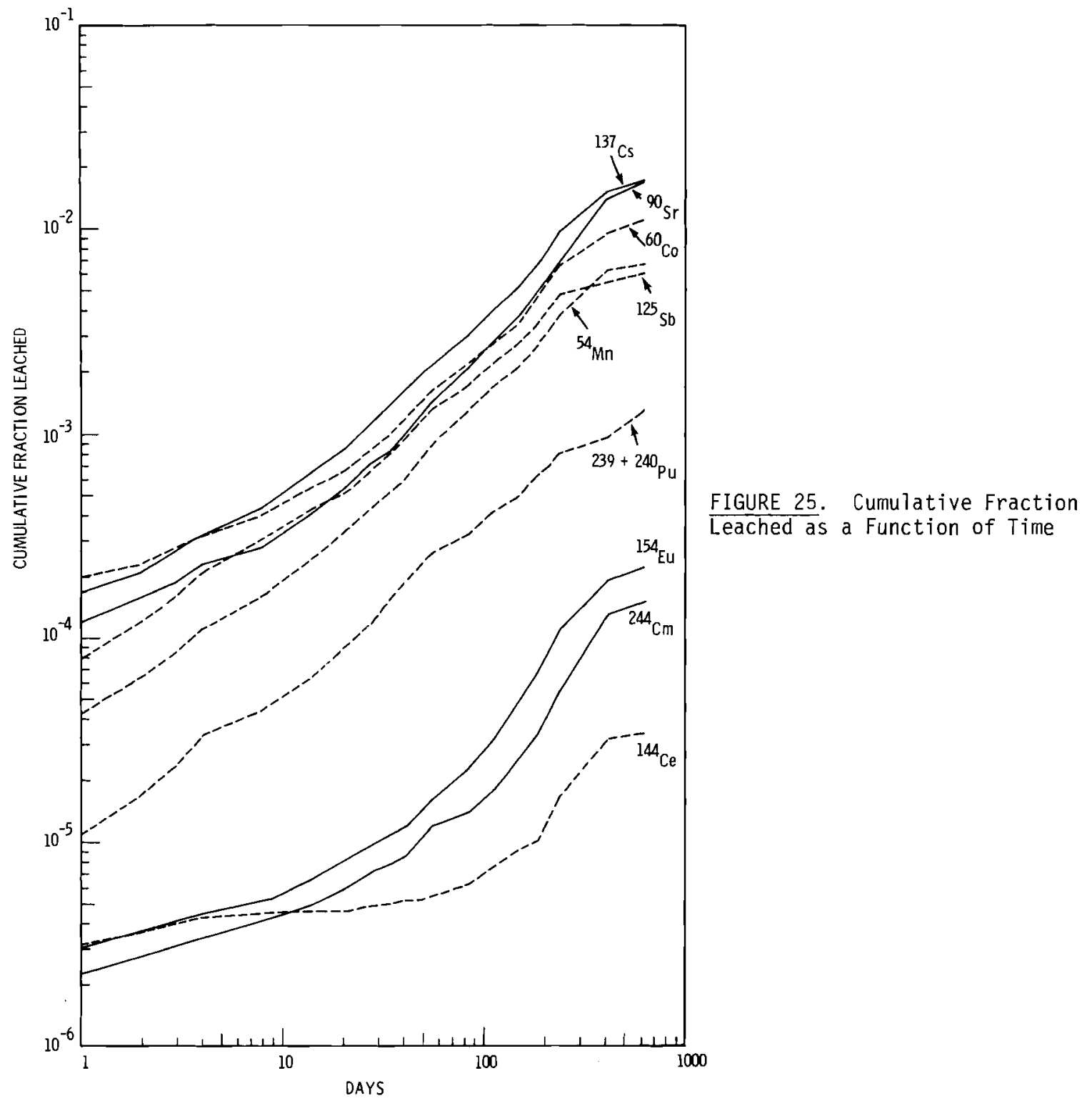

TABLE 12. Slopes Calculated from Cumulative Fraction Leached Curves

\begin{tabular}{|c|c|c|c|c|c|c|c|c|c|c|}
\hline \multirow{3}{*}{$\frac{\text { Isotope }}{54_{\mathrm{Mn}}}$} & \multicolumn{2}{|c|}{$\begin{array}{c}\text { Time }= \\
1-10 \text { Days }\end{array}$} & \multicolumn{2}{|c|}{$\begin{array}{c}\text { Time }= \\
10-56 \text { Days }\end{array}$} & \multirow{2}{*}{$\begin{array}{r}\text { Time } \\
56-100 \\
\text { Bottom }\end{array}$} & & \multicolumn{2}{|c|}{$\begin{array}{r}\text { Time }= \\
100-240 \quad \mathrm{D}\end{array}$} & \multicolumn{2}{|c|}{$\begin{array}{r}\text { Time }= \\
240-6390 \\
\end{array}$} \\
\hline & Botton & Top & Bottom & Top & & & Bottom & Top & Bottom & Top \\
\hline & 0.65 & 0.30 & 0.90 & 0.87 & 0.92 & 0.94 & 1.00 & 1.25 & 0.59 & 0.38 \\
\hline${ }^{60} \mathrm{Co}$ & 0.35 & 0.38 & 0.68 & 0.81 & 0.76 & 0.89 & 1.03 & 1.06 & 0.64 & 0.53 \\
\hline${ }^{0} \mathrm{Sr}$ & 0.43 & 0.25 & 0.87 & 0.64 & 0.97 & 0.81 & 1.13 & 1.06 & 0.93 & 0.74 \\
\hline & 0.63 & 0.48 & 0.77 & 0.55 & 0.73 & 0.78 & 0.97 & 0.84 & 0.24 & 0.44 \\
\hline${ }^{7} \mathrm{Cs}$ & 0.48 & 0.43 & 0.84 & 0.92 & 0.89 & 1.11 & 1.06 & 1.19 & 0.60 & 0.56 \\
\hline & 0.15 & 0.11 & 0.11 & 0.13 & 0.43 & 0.16 & 0.94 & 0.56 & 0.71 & 0.80 \\
\hline & 0.26 & 0.28 & 0.61 & 0.45 & 0.91 & 0.43 & 1.50 & 1.03 & 0.71 & 0.56 \\
\hline${ }^{239} \mathrm{Pu}$ & 0.66 & 024 & 0.94 & 0.84 & 0.64 & 0.66 & 0.34 & 0.72 & 0.51 & 0.19 \\
\hline${ }^{4} \mathrm{Cm}$ & 0.29 & 0.35 & 0.65 & 0.48 & 0.51 & 0.25 & 1.38 & 0.81 & 1.02 & 0.47 \\
\hline Ave. & 0.43 & 0.31 & 0.71 & 0.63 & 0.75 & 0.67 & 1.09 & 0.95 & 0.66 & 0.52 \\
\hline & & & & & & & & & & \\
\hline
\end{tabular}




\section{PHASE BEHAVIOR}

This section concerns crystalline phases observed in glasses produced in both laboratoryand engineering-scale systems. The detailed qualitative and quantitative analyses are based on laboratory-scale glasses which accurately duplicate the glass compositions, but not the radioactivity. Fully radioactive laboratory-scale materials and engineering-scale products have also been tested. Phase behavior studies during the past reporting period have included qualitative analysis on the two new glass formulations (77-107 and 77-260), as well as quantitative analysis of the 76-68 composition.

\section{QUALITATIVE ANALYSIS}

Previous work has outlined in detail the formation of primary and secondary devitrification products in reference glass 72-68 as a function of hold times at specific temperatures. (10 Supplemental lab work has now related these results to those of programmed cooling rates from the glass melt temperature. The purpose for these studies is to establish an experimental method not only to evaluate actual canister behavior, but also to contribute to more fundamental analyses of the kinetics. Thus, controlled cooling rates were used to take a glass from its melt temperature to room temperature. The cooling rates included air quench $\left(\sim 1000^{\circ} \mathrm{C} / \mathrm{hr}\right)$ and furnace cooling at $130^{\circ} \mathrm{C} / \mathrm{hr}, 50^{\circ} \mathrm{C} / \mathrm{hr}, 25^{\circ} \mathrm{C} / \mathrm{hr}, 12.5^{\circ} \mathrm{C} / \mathrm{hr}$, and $6.25^{\circ} \mathrm{C} / \mathrm{hr}$.

The total crystallinity from the cooling treatment is evaluated by comparing the integrated area of the diffraction trace to that of crystalline standards. With respect to expected thermal histories, (2) an average cooling rate of $12.5^{\circ} \mathrm{C} / \mathrm{hr}$ would closely duplicate the centerline temperature history for the 12-in. dia full-scale canisters, while the slower rate of $6.25^{\circ} \mathrm{C} / \mathrm{hr}$ would yield "worst case" behavior.

Figure 26 shows the percent crystallinity for the programmed slow-cool of reference glass 72-68 and glass 76-68. As cooling rate decreases, the total crystallinity in glass 72-68 increases from about $12 \%$ at $50^{\circ} \mathrm{C} / \mathrm{hr}$ to over $40 \%$ at $6.25^{\circ} \mathrm{C}$. In contrast, glass $76-68$ shows a very gradual rise in crystallinity from $8 \%$ to about $10 \%$ total over the entire range studied. Clearly, glass 72-68 is sensitive to cooling behavior and its cooling history must be carefully controlled if devitrification is to be avoided. Glass 76-68, on the other hand, is nearly cooling-rate independent, at least within the range studied, and therefore has more flexible processing control needs.

Additional qualitative analyses have been performed on two other simulated waste glass compositions representing the 77-107 and 77-260 compositions. Table 13 highlights the basic differences among the four glasses either completed or under study. (Tables 1 and 3 give the compositions of these glasses.) Figure 27 illustrates the X-ray diffraction patterns of these glasses after vitrification and annealing at $850^{\circ} \mathrm{C}$ for two months. Glass 76-68 appears to be least affected by devitrification in overall crystallinity and type of crystals formed. Measurements of relative percent crystallinity based on integrated areas of the $X$-ray diffraction traces were $76-68=5 \%, 77-107=9 \%, 77-260=33 \%$ and $72-68$ (reference $)=37 \%$. 


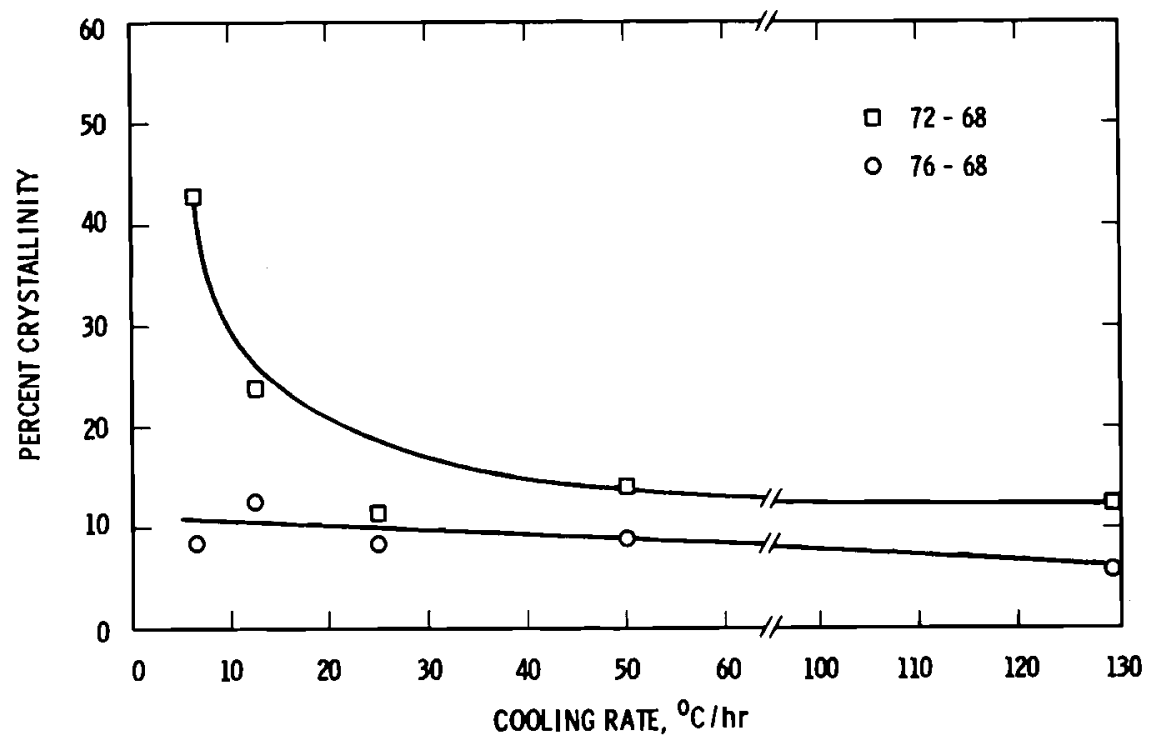

FIGURE 26. Crystal Yield Versus Cooling Rate

TABLE 13. Main Characteristics of Glass $72-68,76-68,77-260$, and 77-107

\begin{tabular}{c} 
Nomencla ture \\
\hline $72-68$ \\
$76-68$ \\
$77-260$ \\
$77-107$
\end{tabular}

Characteristics

High $\mathrm{Zn}$ glass frit; clean waste stream High $\mathrm{Fe}, \mathrm{Na}$

High Gd, Na; glass frit high in $\mathrm{Ti}, \mathrm{Cu}$

Clean waste stream

Figure 28 shows the typical microstructures present at 800 to $850^{\circ} \mathrm{C}$ after two months anneal time for the four glasses studied. The major phases present in glass 72-68 and 76-68 have already been discussed. (2) Major phases identified in glass 77-260 by SEM analysis were high principally in $\mathrm{Ti}, \mathrm{Gd}$, and $\mathrm{Nd}$, or $\mathrm{Gd}, \mathrm{P}, \mathrm{Nd}$, and $\mathrm{Ca}$. X-ray diffraction analysis on this glass indicated the presence of $\mathrm{Gd}_{2} \mathrm{Ti}_{2} \mathrm{O}_{7}$, as well as one other minor unknown phase. For glass 77-107, SEM analysis indicated phases high in $\mathrm{Pd}$; $\mathrm{Ru} ; \mathrm{Cr}, \mathrm{Zn}$, and $\mathrm{Fe}$; $\mathrm{Nd}$, La, Ce, Ca, K, and Si; $\mathrm{Ca}$ and $\mathrm{Mo}$; and $\mathrm{Ti}$. In crystalline form, X-ray diffraction showed $\mathrm{TiO}_{2}$, $\mathrm{RuO}_{2}$, and $\mathrm{CeO}_{2}$. The probable phase ( $\mathrm{Fe}, \mathrm{Cr}, \mathrm{Zn})_{3} \mathrm{O}_{4}, \mathrm{CaMoO}_{4}$ and an Apatite phase $\mathrm{Ca}_{2} \mathrm{RE}_{4}\left(\mathrm{SiO}_{2}\right)_{6} \mathrm{O}_{2}$ are too weak for $X$-ray detection under these conditions of time and temperature.

QUANTITATIVE ANALYSIS: $(76-68)$ GLASS

Quantitative $X$-ray diffraction analysis has been performed on glass 76-68 composition (high $\mathrm{Fe}, \mathrm{Na}$ ) for samples annealed between $300^{\circ} \mathrm{C}$ and $900^{\circ} \mathrm{C}$ for one day, one week, and two months. Figure 29 shows the $X$-ray diffraction traces for the vitreous, as-prepared glass (A) and a typical devitrified sample (B). Photomicrographs illustrating most of the typical microstructures seen in this glass system appear in Figure 30.

There are three major phases in this glass system at these times and temperatures which can be readily detected by $\mathrm{X}$-ray diffraction: Spinel $\left.[\mathrm{Ni}, \mathrm{Fe})_{2} \mathrm{O}_{4}\right]$, fluorite $\left[(\mathrm{Ce}, \mathrm{U}) \mathrm{O}_{2}\right]$, and $\mathrm{RuO}_{2}$. Three additional secondary phases also exist, identified by SEM examination: $\mathrm{CaMoO}_{4}$, 


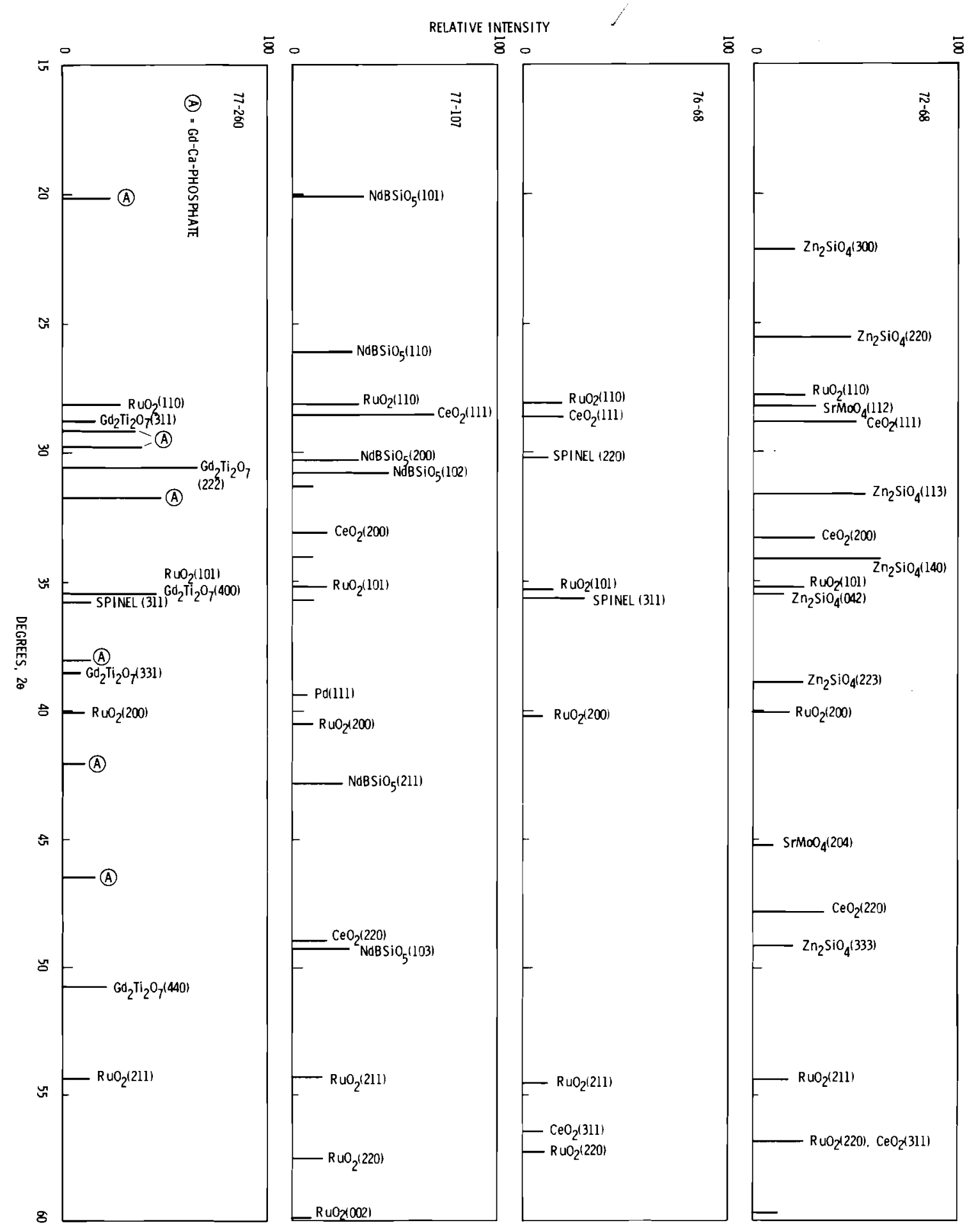

FIGURE 27. X-ray Diffraction Patterns for Glasses After Annealing at $850^{\circ} \mathrm{C}$ for Two Months 

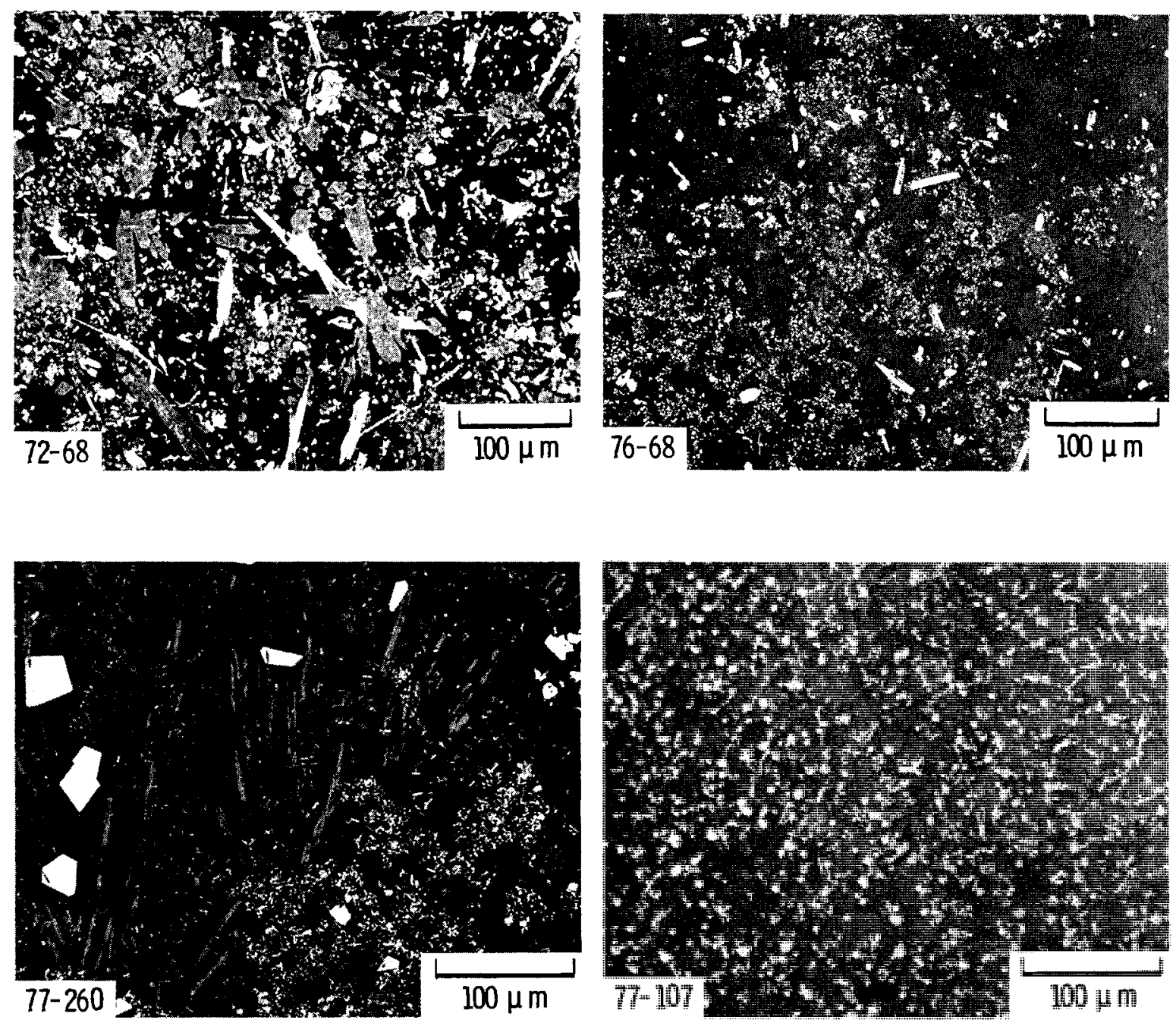

FIGURE 28. Microstructures for Glasses After Thermal Annealing at $850^{\circ} \mathrm{C}$ for Two Months
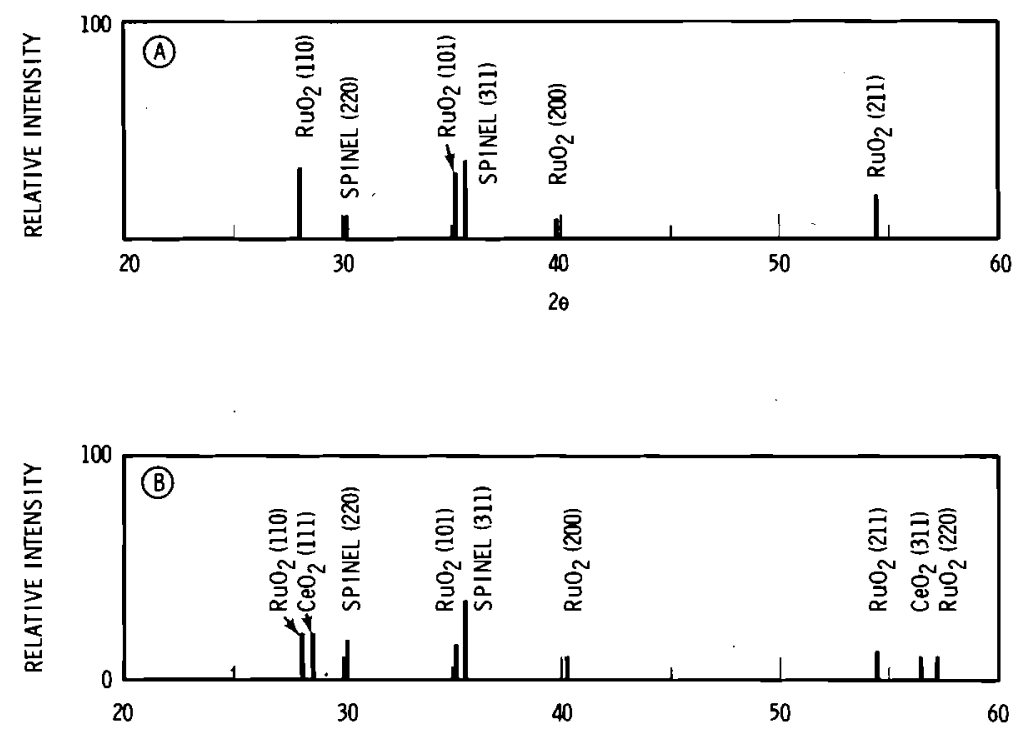

FIGURE 29. X-ray Diffraction Patterns for Glass 76-68: A. Vitreous; B. Devitrified $750^{\circ} \mathrm{C}-$ Two Months 

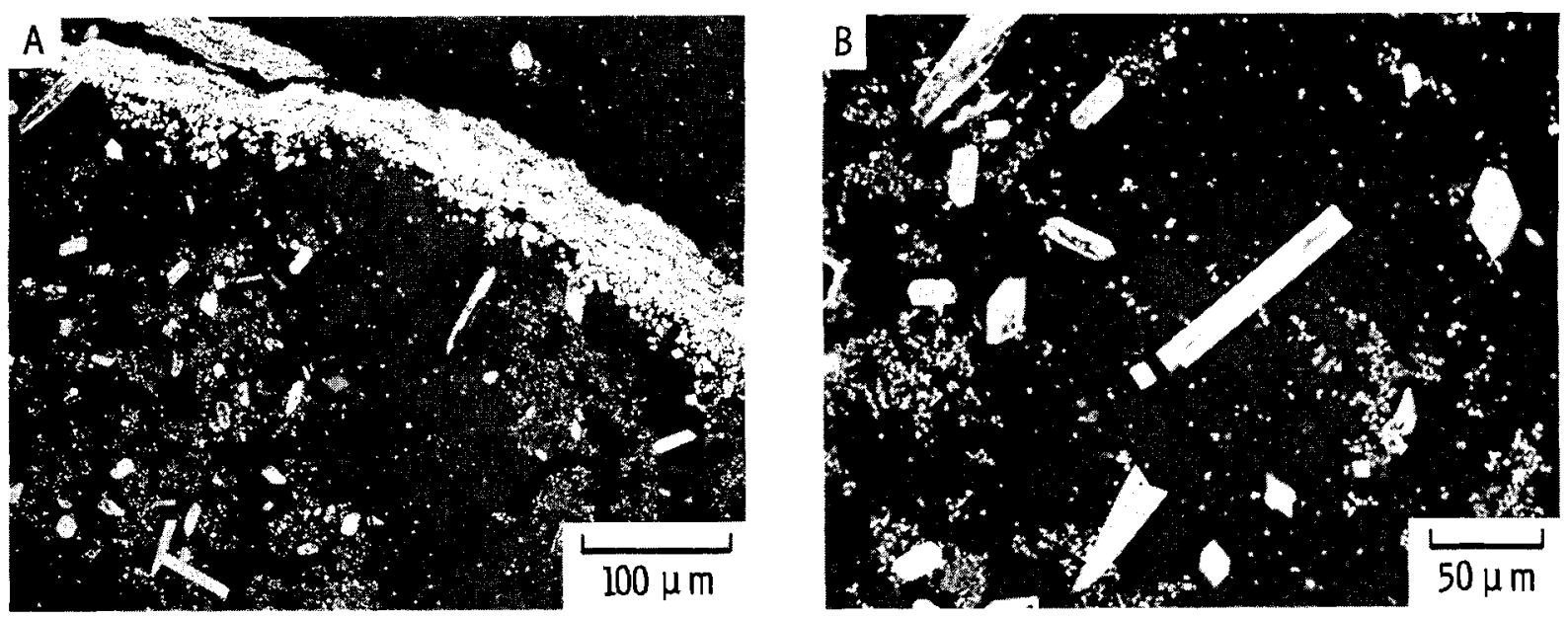

FIGURE 30. Typical Microstructures in Devitrified 76-68 Glass

$\mathrm{TiO}_{2}$, and Iron-Silicate. However, their detection is marginal by $x$-ray diffraction (i.e., $<0.5 \mathrm{wt} \%)$. A secondary spinel is also formed, as in Figure 30-A, which results from high temperature spalling of the canister during the vitrification process.

Formation of the cerium-uranium fluorite, illustrated in Figure 31, follows a typical nucleation and growth pattern. Even though the temperature of maximum formation shifts to lower values as time increases $\left(850^{\circ} \mathrm{C} / 1 \mathrm{da}--750^{\circ} \mathrm{C} / 1 \mathrm{wk}--700^{\circ} \mathrm{C} / 2 \mathrm{mo}\right)$, the total amount formed is below 2 wt\%.

Formation of the iron-nickel spinel phase is $i l$ lustrated in Figure 32 , showing the presence of spinel in the as-melted condition by a constant composition ( $\sim 2 \mathrm{wt}$ ) at temperatures less than $500^{\circ} \mathrm{C}$. The spinel phase concentration does increase at all times between the temperature range of $600^{\circ} \mathrm{C}$ and $850^{\circ} \mathrm{C}$, but with more scatter in the data and less sensitivity to time than observed for the $\mathrm{CeO}_{2}$ phase ingrowth.

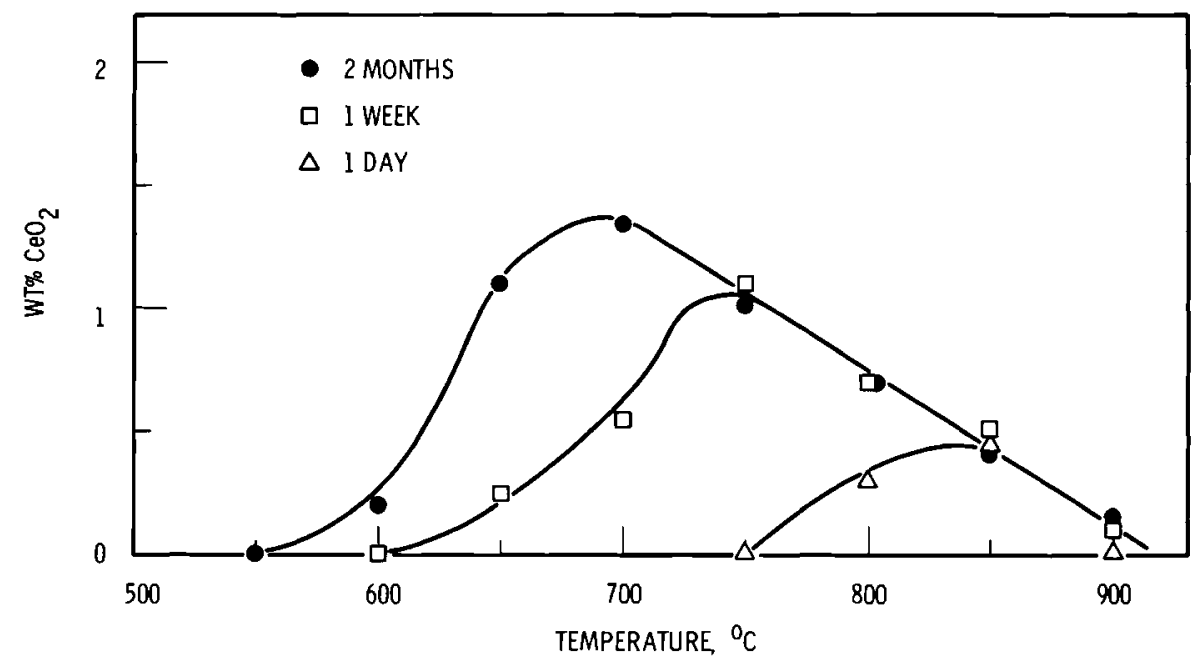

FIGURE 31. Growth of Cerium-Uranium Fluorite Phase 


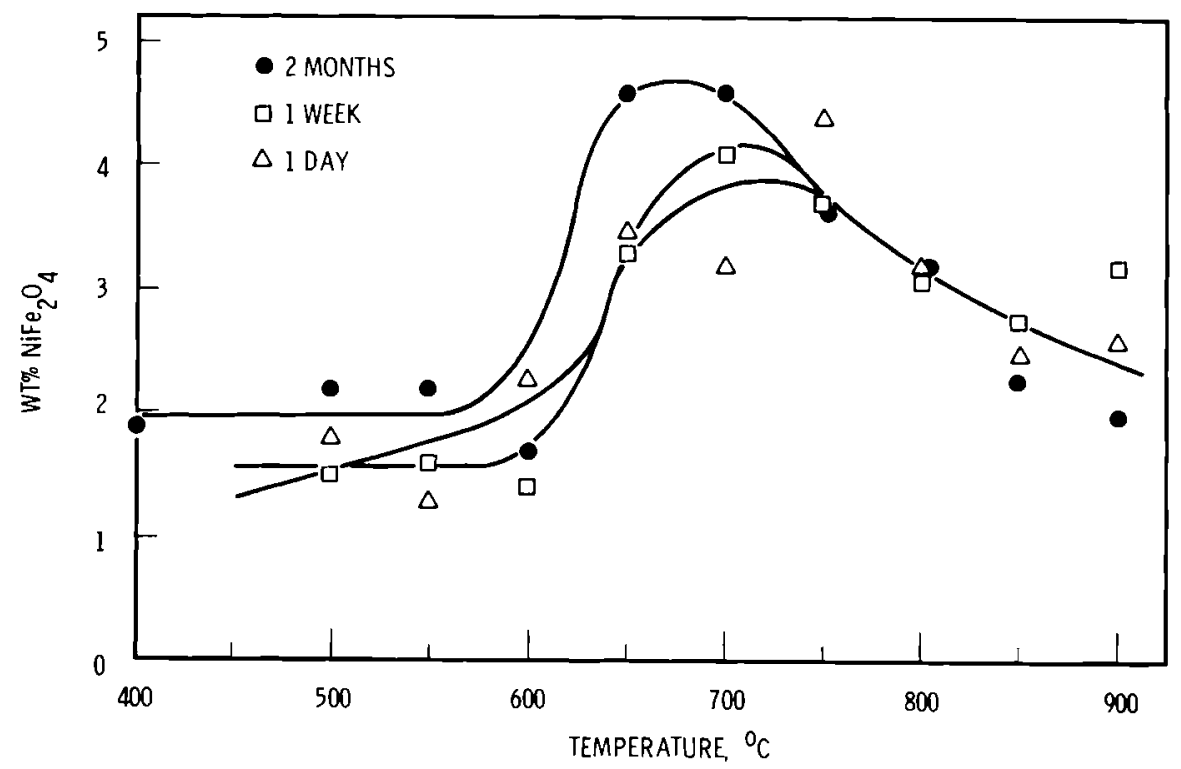

FIGURE 32. Growth of Iron-Nickel Spinel Phase

Calculated lattice constant values for the three principal phases appear in Table 14, along with theoretical values from the ASTM Powder Diffraction Files. The range in the calculated lattice constant for the fluorite phase reflects the varying amounts of uranium and possible RE in the fluorite structure as a function of time and temperature. For the spinel phase, variations can be attributed to changing levels of iron, chrome, zinc, and nickel in the spinel lattice.

In the short term (i.e. $\leq 2$ months), the 76-68 glass formulation demonstrates an acceptable glass waste form. Not only is it thermally stable, as illustrated in Figure 26, it is insensitive to compositional variations. From a devitrification standpoint, total crystal yield is also small ( $210 \mathrm{wt} \%)$. Those crystals that do form are leach resistant, probably stable with respect to radiation damage, and do not appear to cause microcracking in the glass.

\section{FULL-LEVEL RADIOACTIVE GLASS ANALYSIS}

Microstructural examination and characterization have been conducted on four waste glass compositions using fully radioactive power waste calcine. The glasses being studied are 72-68, 76-68, 77-107, and 77-123 waste glass formulations. The calcine used was obtained from LWR fuel with $28027 \mathrm{MWd} / \mathrm{MTU}$ burnup, out of reactor approximately $31 / 2$ years.

TABLE 14. Lattice Constants Calculated for Primary Phases in Glass 76-68

\begin{tabular}{lll} 
& \multicolumn{2}{c}{ Lattice Constant } \\
\cline { 2 - 2 } $\mathrm{CeO}_{2}$ & $\frac{\text { CaTcuTated }}{\mathrm{a}_{0}=5.41 \AA}$ & $\mathrm{a}_{0}=5.43-5.41 \AA$ \\
$\mathrm{NiFe}_{2} \mathrm{O}_{4}$ & $\mathrm{a}_{0}=8.34 \AA$ & $\mathrm{a}_{0}=8.40-8.37 \AA$ \\
$\mathrm{RuO}_{2}$ & $\mathrm{a}_{0}=4.49 \AA$ & $\mathrm{a}_{0}=4.49 \AA$ \\
& $\mathrm{C}_{0}=3.11 \AA$ & $\mathrm{c}_{0}=3.09 \AA$
\end{tabular}


Microstructural Examination

Full-Level glasses were made on a laboratory scale ( 80 grams) using standard glass frits developed for each waste type, with specific adjustments for variation in reprocessing chemicals. Once batch adjustments were made and initial vitrification complete, one batch from each glass melt was air quenched to room temperature while another batch was slow cooled $\left(-6.25^{\circ} \mathrm{C} / \mathrm{hr}\right)$ to provide a "standard" devitrified glass. Figure 33 illustrates the typical microstructure of the four fully radioactive glasses in the vitreous or as-prepared condition, and Figure 34 illustrates the same glasses after the standard slow-cool devitrification. Table 15 lists the quantitative microprobe analysis of six major constitutents determined from glass analyses, but which were converted to concentrations in the initial calcine.

In Table 16, known additions of glass frit components are compared between the standard nonradioactive reference glass and the fully radioactive reference glass to establish a correlation factor between measurements on the two glasses. Table 16 illustrates the experimental
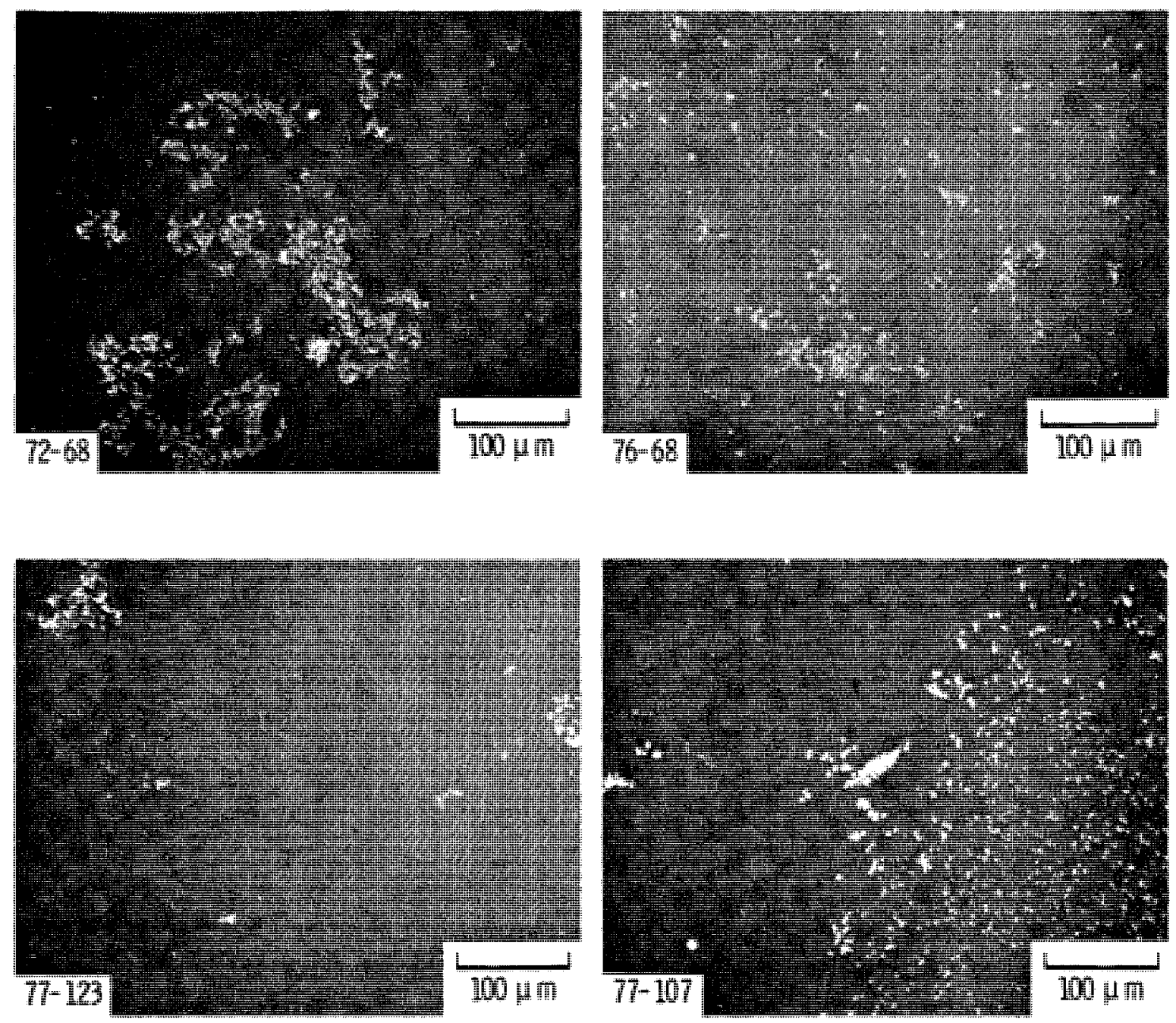

FIGURE 33. Typical Microstructure of Vitreous Fully Radioactive Glasses - 72-68, 76-68, 77-123, and 77-107 

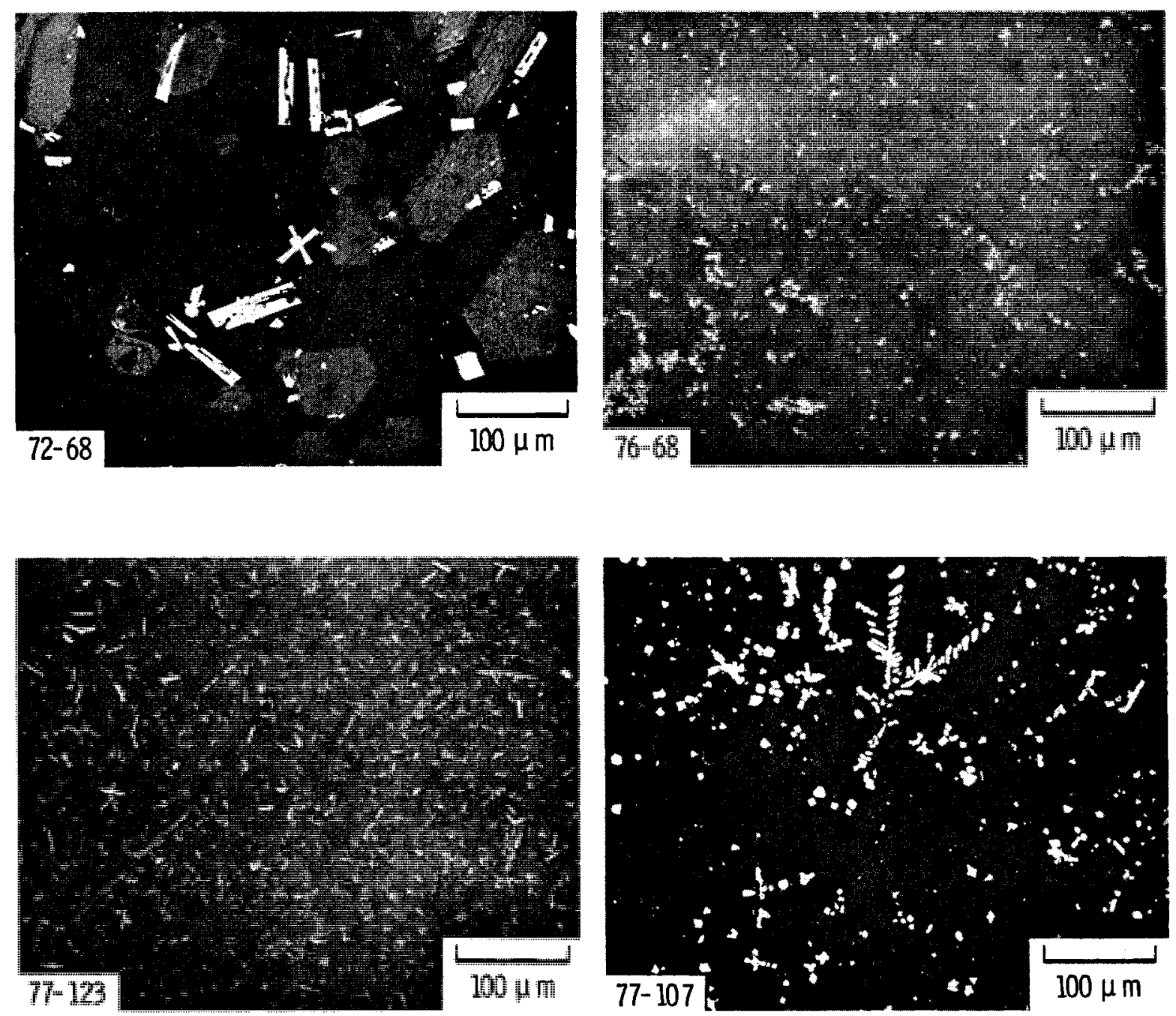

FIGURE 34. Full-Level Radioactive Glasses in the Devitrified Condition

TABLE 15. Microprobe Analysis of Six Major Constituents in the Full-Level Calcine

\begin{tabular}{|c|c|c|c|}
\hline Element & $\begin{array}{c}\text { Theoretical } \\
\text { Percent } \\
\end{array}$ & $\begin{array}{l}\text { Measured wt\% } \\
\text { in Calcine }\end{array}$ & $\begin{array}{l}\text { Measured/ } \\
\text { Theoretical }\end{array}$ \\
\hline $\mathrm{Fe}$ & 1.9 & 1.1 & 0.6 \\
\hline $\mathrm{Sr}$ & 5.1 & 4.5 & 0.9 \\
\hline Cs & 4.8 & 3.1 & 0.6 \\
\hline $\mathrm{Ce}$ & 4.8 & 4.5 & 0.9 \\
\hline $\mathrm{Nd}$ & 7.1 & 3.6 & 0.5 \\
\hline U & 3.1 & 35.0 & 11.0 \\
\hline
\end{tabular}

error in measuring concentrations in HLW glass with the microprobe. Using only one standard deviation, errors appear to be about $\pm 20 \%$. It follows that the differences shown in Table 15 are significant for $\mathrm{Fe}, \mathrm{Ca}, \mathrm{Nd}$ and $\mathrm{U}$; other elements not measured also probably occur in different concentrations than those assumed. 
TABLE 16. Intercomparison of Glass Frit Components for Fully

Radioactive and Nonradioactive Glass 72-68

\begin{tabular}{cccc} 
Element & $\begin{array}{c}\text { Weighed } \\
\text { Additions }(w \mathrm{t} \%)\end{array}$ & $\begin{array}{c}\text { Measured } \\
\text { Full Level }\end{array}$ & $\begin{array}{c}\text { Measured/ } \\
\text { Weighed }\end{array}$ \\
\cline { 2 - 3 } & 1.7 & $\frac{2.0}{1.2}$ & 1.1 \\
$\mathrm{Ki}$ & 12.8 & 13.9 & 0.8
\end{tabular}

While the reference glass 72-68 was found to contain ten times the expected uranium content, and as could be expected, did show microstructural differences in devitrified form, the other glasses, because of higher allowable uranium limits and higher concentrations of inert chemicals, contained only three to four times anticipated uranium levels. The 76-68 and 77123 glasses did not show any adverse effects which could be attributed directly to increased uranium. As Figure 34 illustrates, however, glass 77-107 did form a dendritic crystal which was high in uranium and did not exist in the nonradioactive system (Figure 28 ).

From the standpoint of overall devitrification, the reference glass (72-68) shows the expected differences between vitreous and devitrified glass, with the noted exception that it has no leachable $\mathrm{SrMoO}_{4}$ phase; however, it does have a high uranium phase. In the 76-68 glass, the vitreous and standard devitrified microstructures are virtually the same. No obvious largescale crystallinity was observed, and the small crystals that were present appear to be melt insolubles. Full-level 77-123 glass does not seem to show the typical microstructures seen in the nonradioactive glass (Figure 28, 77-260). Crystals in the full-level glass are fine and highly dispersed, while in the nonradioactive glass there is a greater percentage of larger crystals. The 77-107 glass does not show significant differences between vitreous and devitrified conditions; however, in this case, both contain the rather large dendritic crystalline phase, which is high in uranium. This glass does not seem to resemble the nonradioactive counterpart (Figure 28), where at least three crystalline phases were observed. Experiments are being continued which include preparation of glasses with compositions closer to the HLW glass preparations. These will resolve the question of the importance of the radiation field on devitrification phenomena.

\section{Macrostructure Examination}

The inhomogeneities identified previously ${ }^{(2)}$ have been investigated by a gamma spectroscopy system which allowed a qualitative analysis of the radioisotope distribution. Laboratory-scale melts $(\sim 100 \mathrm{~g})$ were sectioned in $1 / 8 \mathrm{in}$. thick transverse sections (numbered 1 through 7 in Figure 35) and were subsequently counted to determine what separation occurred. The activity was corrected for the amount of material in the sections. Figure 35 shows the distribution of the radioisotopes in the glass formed from calcined waste derived from fuel with a burn-up of 54,000 MWd/MTU. The concentration of Rh-106, which is the daughter of Ru-106, great1y increases near the top of the sample (section 7). Ruthenium is insoluble in the glass, and insoluble materials have previously been observed to rise with bubbles during the glass-fining period. Slight increases of $\mathrm{Zr}$, Ce and RE oxides can also be observed near the top for the same reason. Cesium is nearly uniformly distributed. 


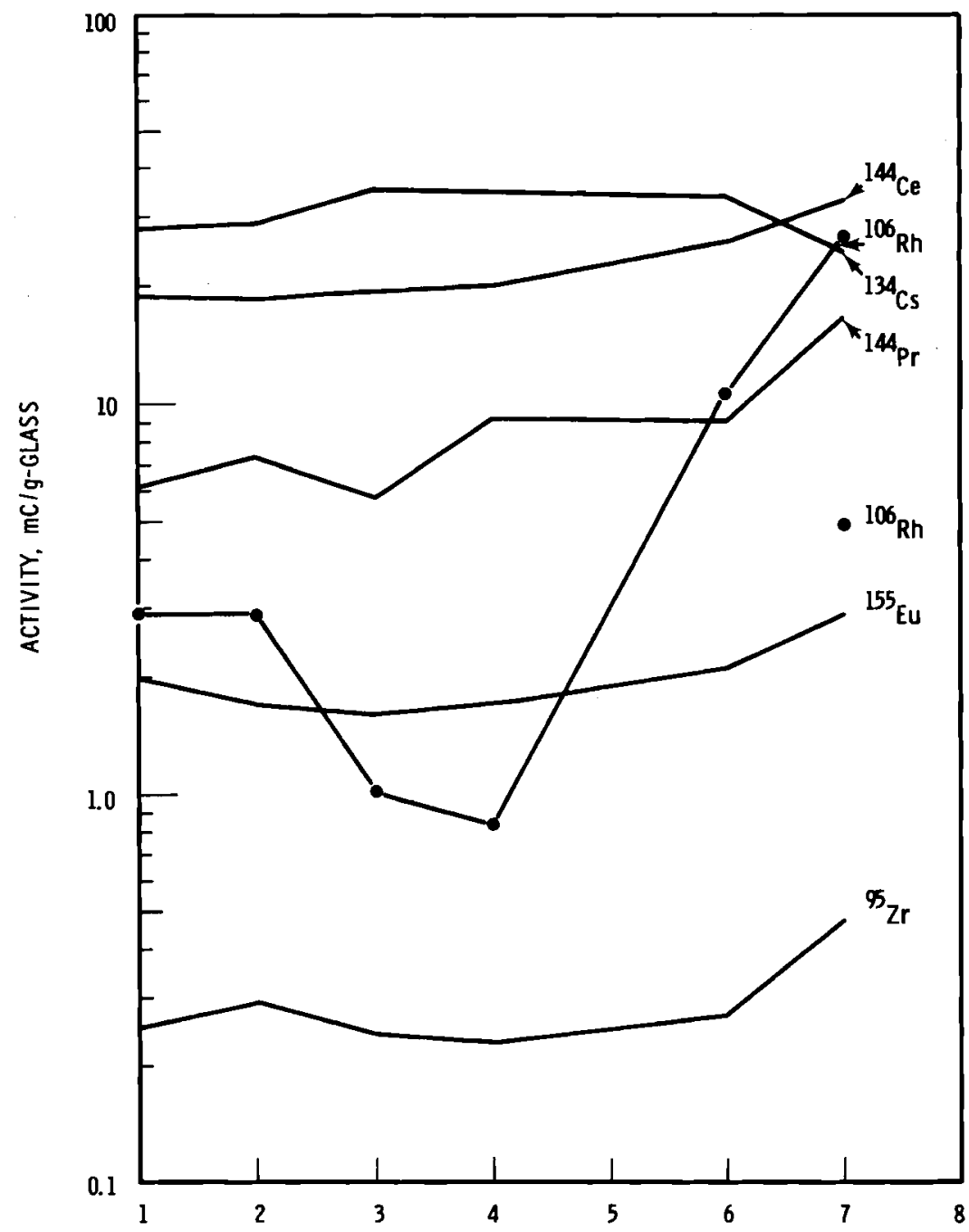

FIGURE 35. Distribution of Radioisotopes from Burnup of 54,000 MWd/MTU

Analysis of two additional melts formed with waste from a fuel with a 28,000 MWd/MTM burnup show similar results. While these results are not conclusive, it appears that potential settling and top surface enrichment may occur with waste glasses containing residual crystals. Residual crystals of $\mathrm{RuO}_{2}$ and $\mathrm{CeO}_{2}$ have been identified in cold laboratory melts, and these materials (or their daughters as in the case of Ru-106) appear to have some separation tendencies. Zirconium and praseodymium may also be present as crystallites, probably in solid solution with $\mathrm{Ce}$ in a fluorite type $\mathrm{MO}_{2-\mathrm{x}}$ phase.

\section{ENGINEERING-SCALE GLASSES}

Waste glass samples from five engineering-scale runs have been evaluated. These glass compositions, shown in Table 17, were prepared to test equipment, and therefore do not correspond directly to the standard compositions. Four of the runs were made with a silicon metal addition to act as a reducing agent to change molybdenum behavior. Two waste types were utilized, PW-7a-2 and PW-8a-2. Table 18 shows the total crystallinity in the melts and the type of crystals in the glass. Possibly due to lower fission product loading, ICM-13 and -18 have the 
TABLE 17. ICM Glass Types

ICM- 13

ICM- 16

ICM- 18

ICM-20

ICM-23
PW-7a-2(1:2.9)75-75

$\mathrm{PW}-7 \mathrm{a}-2(1: 2) 75-75+1.5 \% \mathrm{Si}$

$\mathrm{PW}-8 \mathrm{a}-2(1: 2) 75-75+1.5 \% \mathrm{Si}$

PW-7a-2(1:2)75-75+1.5\% Si

PW-7a-2(1:2)76-199+1.5\% Si

\section{TABLE 18. Crystalline Phases in ICM Glasses}

\begin{tabular}{|c|c|c|c|c|c|}
\hline \multirow{3}{*}{$\frac{\text { Glass }}{(72-68)}$} & Compound & Structure & \multicolumn{2}{|c|}{ Lattice Constant $\AA$} & wt\% \\
\hline & $2 \mathrm{n}_{2} \mathrm{SiO}_{4}$ & Hexagona ? & \multicolumn{3}{|c|}{$\mathrm{a}_{\mathrm{a}}=13.97 \AA$} \\
\hline & & & \\
\hline & $(\mathrm{Ca}, \mathrm{Sr}, \mathrm{Ba}) \mathrm{MoO}_{4}$ & Tetragonal & \multicolumn{3}{|c|}{$\begin{array}{l}a_{0}=5.38 \\
c_{0}=12.03\end{array}$} \\
\hline & $\left(\mathrm{Ce}, \mathrm{Zr}, \mathrm{RE}^{3+}\right) \mathrm{O}_{2-x}$ & Cub ic & \multicolumn{3}{|l|}{$a_{0}=5.39$} \\
\hline & $\mathrm{RuO}_{2}$ & Tetragona 1 & \multicolumn{3}{|l|}{$\begin{array}{l}a_{0}=4.50 \\
c_{0}=3.10\end{array}$} \\
\hline & $\mathrm{Ca}\left(\mathrm{RE}^{3+}\right)_{8}\left(\mathrm{SiO}_{4}\right)_{6}$ & Hexagonal & \multirow{2}{*}{\multicolumn{3}{|c|}{$\begin{array}{l}a_{0}=9.54 \\
c_{0}=7.16\end{array}$}} \\
\hline & & & & & \\
\hline & Pd & Cub ic & \multicolumn{3}{|l|}{$a_{0}=3.90$} \\
\hline & $(\mathrm{Zr}, \mathrm{Ni})(\mathrm{Fe}, \mathrm{Cr})_{2} \mathrm{O}_{4}$ & Cub ic & \multicolumn{3}{|l|}{--} \\
\hline \multirow[t]{5}{*}{ ICM-13 Glass } & $\mathrm{CeO}_{2}$ & Cubic & \multicolumn{2}{|l|}{$a=5.38$} & \multirow{3}{*}{$\begin{array}{l}6 \\
1.5\end{array}$} \\
\hline & $\mathrm{B}-\mathrm{Zn}_{2} \mathrm{SiO}_{4}$ & Triclinic & $\mathrm{a}=5.10$ & $b=9.94$ & \\
\hline & & & \multicolumn{2}{|c|}{$\begin{aligned} c & =15.90 & & =90^{\circ} \\
& =97^{\circ} & & =119^{\circ}\end{aligned}$} & \\
\hline & $(\mathrm{La}, \mathrm{Ce}) \mathrm{PO}_{4}$ & Monoc linic & \multirow{2}{*}{\multicolumn{2}{|c|}{.-}} & \multirow{2}{*}{2} \\
\hline & $\mathrm{ZnCr}_{2} \mathrm{O}_{4}$ & Cubic & & & \\
\hline \multirow[t]{6}{*}{ ICM-16 GI ass } & $(\mathrm{Ce}, \mathrm{La}) \mathrm{PO}_{4}$ & Monoclinic & $a=6.77$ & $b=7.01$ & 16 \\
\hline & & & $c=6.43$ & $=103^{\circ} 10^{\prime}$ & \\
\hline & $\mathrm{Zn}_{2} \mathrm{MO}_{3} \mathrm{O}_{8}$ & Hexagonal & $a=5.74$ & $c=9.94$ & 3.5 \\
\hline & $(\mathrm{Ce}, \mathrm{Zr}, \mathrm{Fe}) \mathrm{O}_{2}$ & Cub ic & \multicolumn{2}{|l|}{$a=5.36$} & 0.5 \\
\hline & $\mathrm{Ni}-\mathrm{Te}$ & -- & \multicolumn{2}{|l|}{--} & - \\
\hline & $\mathrm{ZnCr}_{2} \mathrm{O}_{4}$ & -- & \multicolumn{2}{|l|}{$-\cdot$} & -- \\
\hline \multirow[t]{2}{*}{ ICM-18 G]ass } & $\mathrm{Zn}(\mathrm{Fe}, \mathrm{Cr})_{2} \mathrm{O}_{4}$ & Cub ic & \multirow{2}{*}{\multicolumn{2}{|c|}{$a=8.42$}} & 7.6 \\
\hline & $(\mathrm{Ce}, \mathrm{Zr}, \mathrm{Fe}) \mathrm{O}_{2}$ & Cubic & & & 0.2 \\
\hline \multirow[t]{3}{*}{ ICM-20 Glass } & $(\mathrm{Ce}, \mathrm{La}) \mathrm{PO}_{4}$ & Monociinic & $a=6.77$ & $D=7.01$ & \multirow[t]{2}{*}{12.5} \\
\hline & & & $c=6.43$ & $=103^{\circ}$ & \\
\hline & $\mathrm{Zn}_{2} \mathrm{Mo}_{3} \mathrm{O}_{8}$ & Hexagona? & $a=5.74$ & $c=9.94$ & 0.9 \\
\hline \multirow[t]{8}{*}{ ICM-23 Glass } & $\mathrm{Cu}$ & Face-centered Cubic & \multicolumn{2}{|l|}{$a=3.62$} & 1.5 \\
\hline & $(\mathrm{Ce}, \mathrm{La}) \mathrm{PO}_{4}$ & Manoclinic & $a=6.77$ & $b=7.01$ & 2.5 \\
\hline & & & $c=6.43$ & $=103^{\circ} 10^{\prime}$ & \\
\hline & $\mathrm{Ce}_{2} \mathrm{Ti}_{2} \mathrm{Si}_{2} \mathrm{O}_{11}$ & Monoclinic & $a=13.6$ & $b=5.68$ & 2.2 \\
\hline & & (Perrierite) & $c=11.7$ & $=113.5^{\circ}$ & \\
\hline & $\mathrm{Ce}_{4} \mathrm{Fe}(\mathrm{FeTi}) \mathrm{Ti}_{2} \mathrm{Si}_{4}{ }_{22}$ & Monoclinic & $a=13.3$ & $b=5.73$ & 5.8 \\
\hline & & (Chevkinite) & $c=11.1$ & $=100.9^{\circ}$ & \\
\hline & $\mathrm{Ca}-\mathrm{Ce}-\mathrm{Nd}-\mathrm{T}$-FeONi-Si-0 & $\begin{array}{l}\text { Hexagona } \mathrm{T} \\
\text { Iso-structure to } \\
\left(\mathrm{Na}_{2} \mathrm{Nd}_{8}\right)\left(\mathrm{SiO}_{4}\right)_{6} \mathrm{~F}_{2}\end{array}$ & $a=9.54$ & $c=7.03$ & 1.1 \\
\hline
\end{tabular}


lowest crystallinity. This may be the result of the difference in frit-to-calcine ratio and the lower fission product content of $\mathrm{PW}-8 \mathrm{a}$.

The lower content of fission product molybdenum also el iminated the formation of the $\mathrm{Zn}_{2} \mathrm{Mo}_{3} \mathrm{O}_{8}$ observed in $\mathrm{ICM}-16$ and -20 . The reducing agent also has an effect on the crystal phases, which can be noted by comparing ICM-13 and ICM-16 crystalline phases: $\mathrm{Zn}_{2} \mathrm{SiO}_{4}$ formed in nonreducing conditions, but $\mathrm{Zn}_{2} \mathrm{MO}_{3} \mathrm{O}_{8}$ formed during the reducing conditions of both ICM- 16 and -20 . The formation of $\mathrm{Zn}_{2} \mathrm{Mo}_{3} \mathrm{O}_{8}$ demonstrates the effectiveness of reducing agents in preventing $\mathrm{Na}_{2} \mathrm{MoO}_{4}$ phase formation and separation. It also shows that metallics can be formed, for example, Ni-Te in ICM-16 and the $\mathrm{Cu}$ in ICM-23, where three crystalline components were observed which contained Ti.

In these pilot-scale canisters the crystallinity varied with sampling location. Figure 36 shows the sampling location for the ICM-23 canister and Figure 37 illustrates the

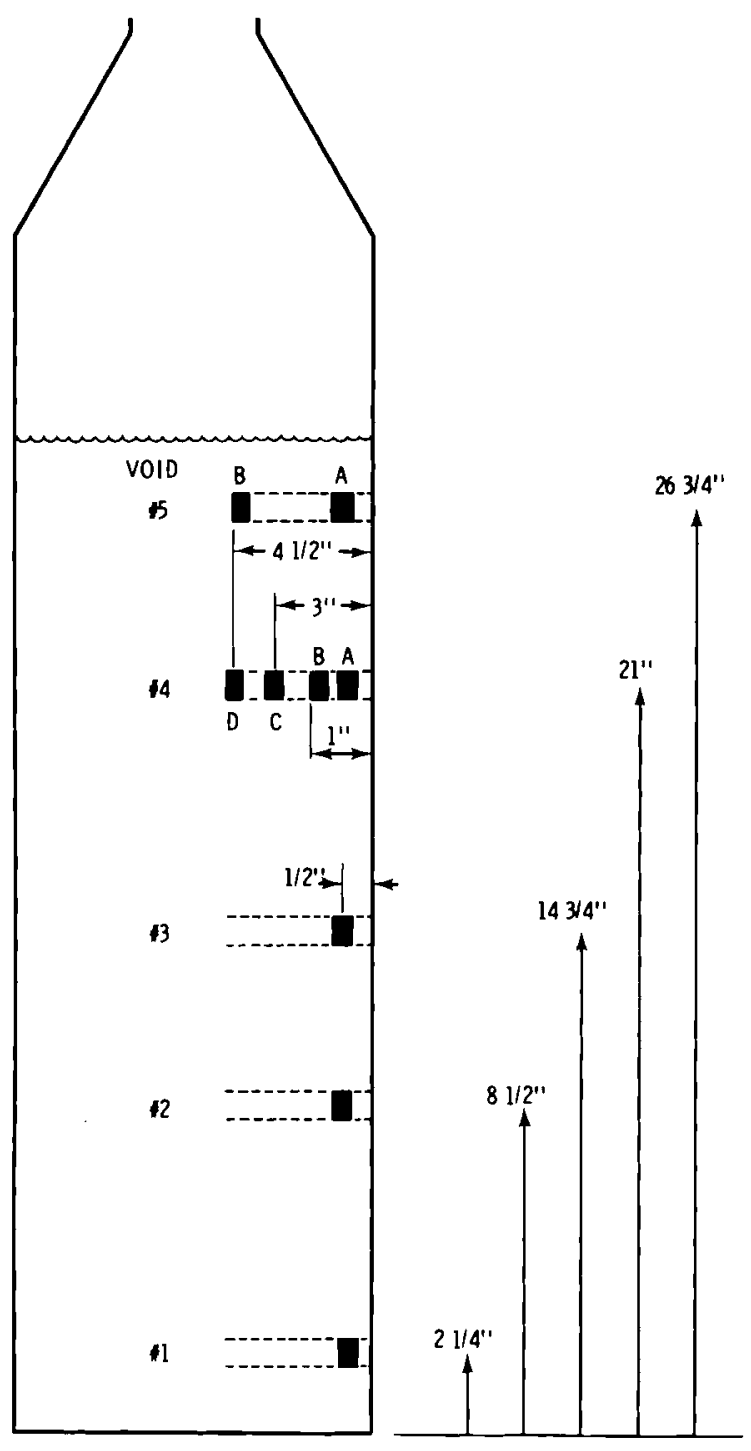

FIGURE 36. Sample Location - ICM-23 


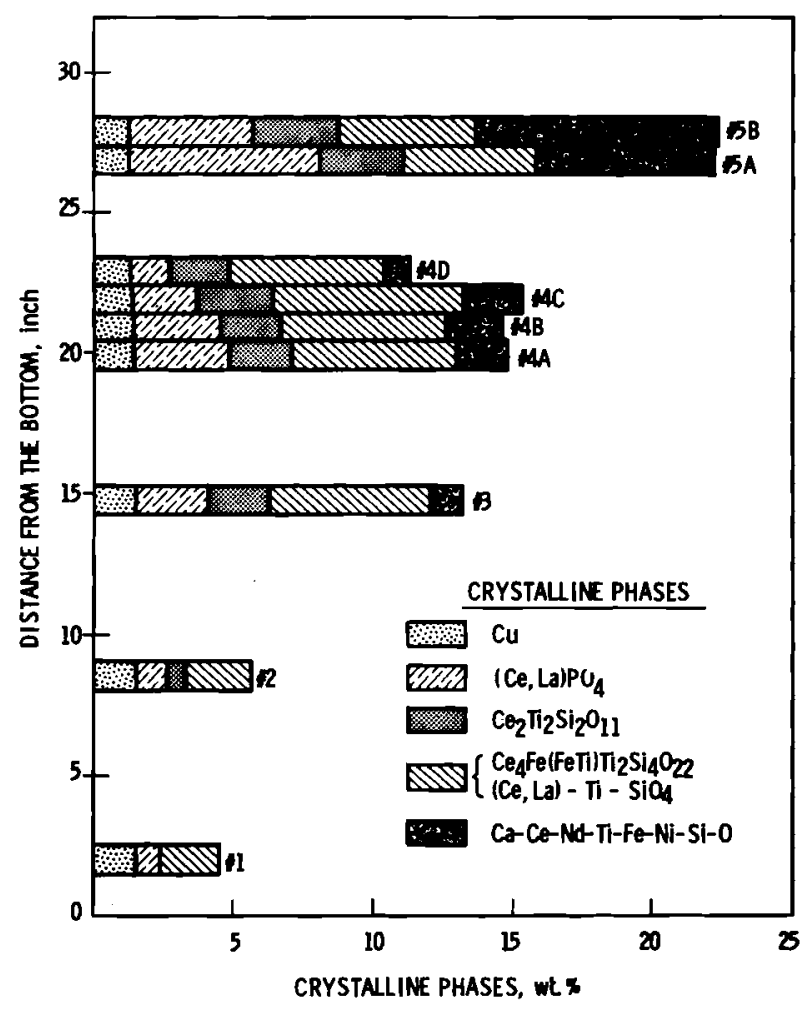

FIGURE 37. Distribution of Crystalline Phases in ICM-23 Glass

distribution of crystalline phases in the ICM-23 glass samples. There was a slight change in the total amount of crystalline phase along the radial sampling direction from $1 / 2$ in. to 4-1/2 in. deep. The distribution of the perrierite $\left(\mathrm{Ce}_{2} \mathrm{Ti}_{2} \mathrm{Si}_{2} \mathrm{O}_{11}\right)$ and the chevkinite $\left(\mathrm{Ce}_{4} \mathrm{Fe}(\mathrm{FeTi})-\right.$ $\mathrm{Ti}_{2} \mathrm{Si}_{4} \mathrm{O}_{22}$ ) phases was fairly even from Sample 3 to Sample 5 . The increase in total crystallinity, from $13.1 \mathrm{wt} \%$ in Sample 3 to $22.5 \mathrm{wt} \%$ in Sample 5, was mostly due to a large increase in the amount of (Ce, La) $\mathrm{PO}_{4}$ and $\mathrm{Ca}-\mathrm{Ce}-\mathrm{Nd}-\mathrm{Ti}-\mathrm{Fe}-\mathrm{Ni}-\mathrm{Si}-\mathrm{O}$ crystalline phases. The uniform distribution of the metallic copper indicates good mixing of the feed material.

The higher content of crystalline phases near the top surface is evidence of the migration of crystalline material with bubbles in the glass, as has been observed previously. Figure 38 shows the morphology of the crystalline phases. Since each crystal type has a unique form, identification can be often made only with an optical microscope. 

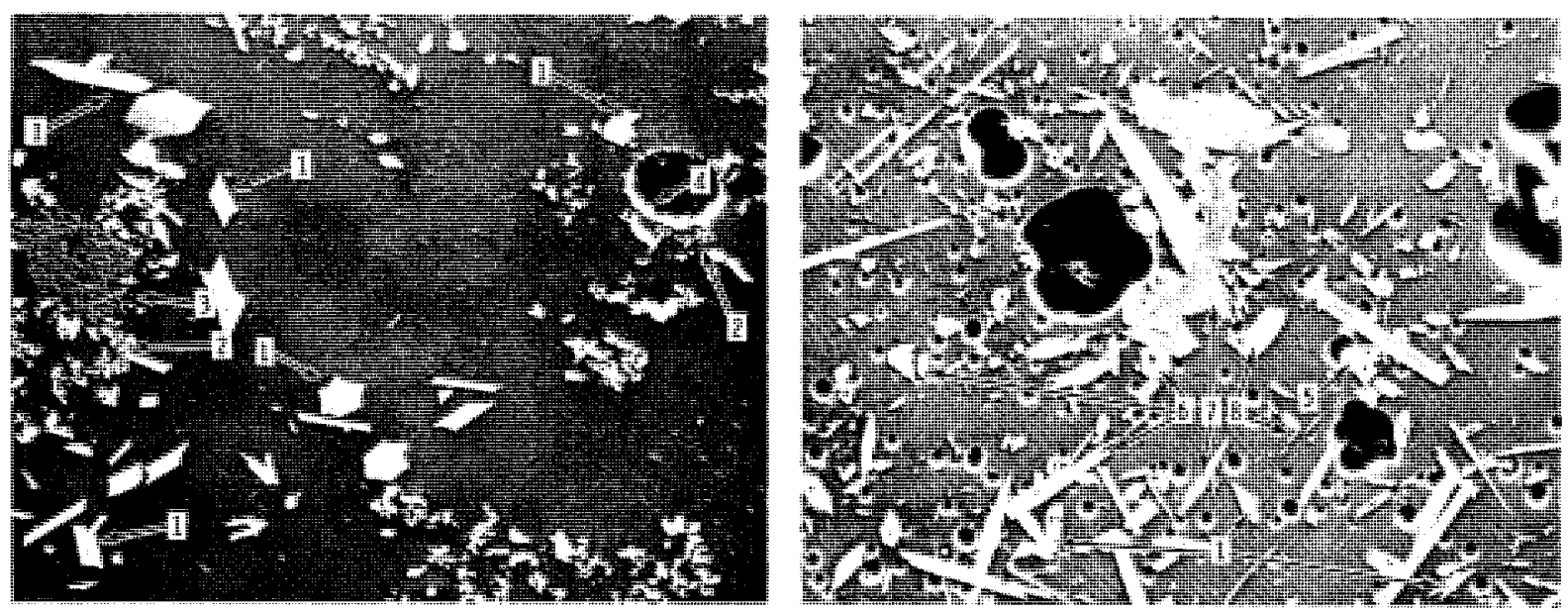
(1) (Ce, La) $\mathrm{PO}_{4}$
(2) $\mathrm{Zn}_{2} \mathrm{Mo}_{3} \mathrm{O}_{8}$
(3) $\mathrm{Zn}(\mathrm{Cr}, \mathrm{Fe}){ }_{2} \mathrm{O}_{4}$
(4) $\mathrm{Ni}-\mathrm{Te}$

(5) $\mathrm{Cu}$

(6) $\mathrm{Ce}_{2} \mathrm{Ti}_{2} \mathrm{Si}_{2}{ }_{11}$

(7) $\mathrm{Ce}_{4} \mathrm{Fe}(\mathrm{Fe} \mathrm{Ti}) \mathrm{Ti}_{2} \mathrm{Si}_{4} \mathrm{O}_{22}$

(8) $\mathrm{Ca}-\mathrm{Ce}-\mathrm{Nd}-\mathrm{Ti}-\mathrm{Fe}-\mathrm{Ni}-\mathrm{Si}-\mathrm{O}$

FIGURE 38. Crystalline Phases in ICM-16-D 


\section{EFFECTS OF RADIATION ON WASTE GLASSES}

It is well known that the intense radiation fields within nuclear waste solids can cause measurable property changes. Since the major cause of radiation damage is decay of the actinide elements ( $\sim 5 \mathrm{MeV}$ per event), most of our work has involved doping with ${ }^{244} \mathrm{Cm}$. We are also exploring electron and ion bombardment-induced changes. Other publications in this area have already appeared in addition to the previous annual report, ${ }^{(2)}$ including studies concerning stored energy $(11)$ helium effects, ${ }^{(12)}$ and radiolysis. (13)

\section{ACCELERATED ALPHA EFFECTS EXPERIMENTS}

In the alpha effects study, ${ }^{244} \mathrm{Cm}_{2} \mathrm{O}_{3}$ is incorporated in specimens of the solidified wastes and observations are made on effects from the dose resulting from the alpha decay. This study concerns macro-scale changes in the glasses. Stored energy buildup and density changes are the two main phenomena which occur under alpha irradiation.

Stored energy is the result of the accumulation of radiation-induced defects in the solids. The annealing of these defects by heating causes a release of energy which can be measured calorimetrically. The quantity of energy released and its release characteristics are of concern in high-level waste management due to the possible hazards of a potential uncontrolled release of energy in the form of heat. The study to date has shown no evidence for stored energy buildup of sufficient quantity to represent a hazard in waste management.

Alpha-induced damage also results in measureable changes in the macro-density of solidified wastes. Our studies have shown that both positive and negative changes occur. The magnitude and direction of the changes are dependent on the composition of the glasses and the extent to which they are devitrified.

During the past year, we extended the investigation of stored energy buildup and density changes in glasses to include high doses and additional solid waste forms. In previous work in the accelerated alpha effects study, $(2,10)$ three glass-like materials were examined. These materials included the reference glass 72-68, a high lead glass (lead glass) and a high silica glass similar to some European formulations (European glass). We now have stored energy and density measurements on these materials after very high alpha irradiations.

In addition, we have reached a dose for the $72-68$ glass of $10^{19} \alpha$ decays $/ g$. The stored energy buildup for this glass, illustrated in Figure 39 , shows a maximum value of $\sim 30 \mathrm{cal} / \mathrm{g}$. Figure 40 compares the stored energy buildup for the lead glass, the European glass, 72-68 glass, and 76-68 glass with doses up to $1.2 \times 10^{18} \mathrm{\alpha} / \mathrm{g}$. The buildup curves are quite similar for these glasses.

Density changes for all of the alpha-irradiated glasses are shown in Figure 41 . The marked difference in density behavior clearly demonstrates the sensitivity to composition. The difference between the vitreous and devitrified 72-68 specimens indicates that density change 


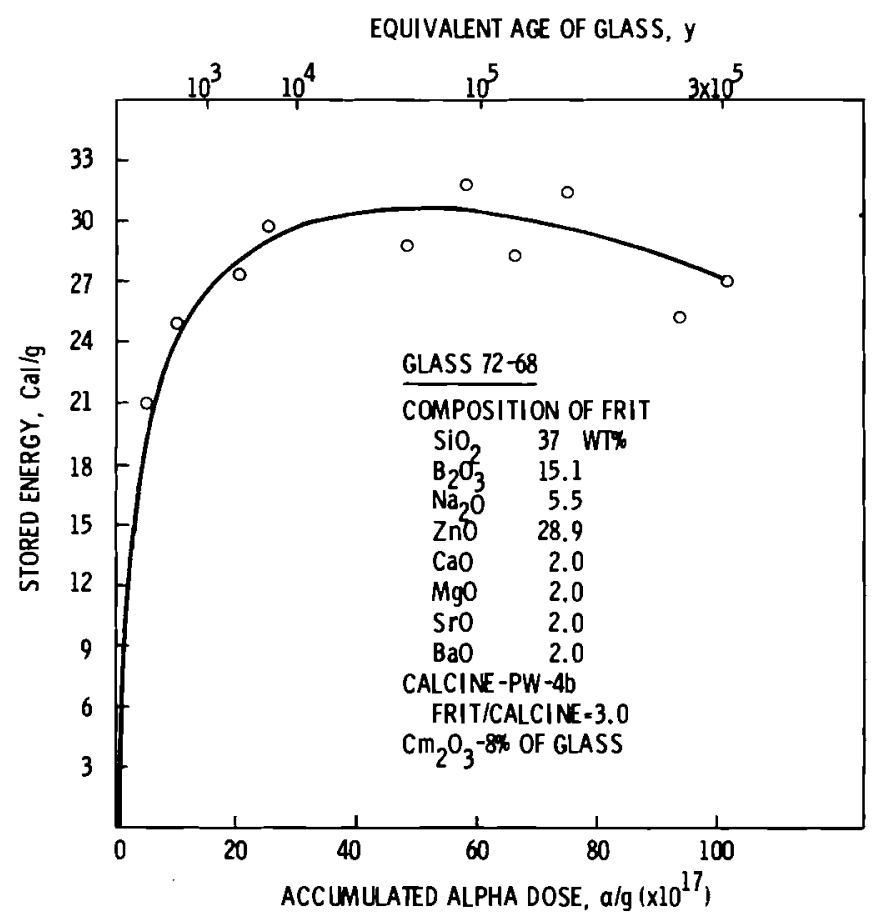

FIGURE 39. Stored Energy Buildup in 72-68 Giass with High Dose

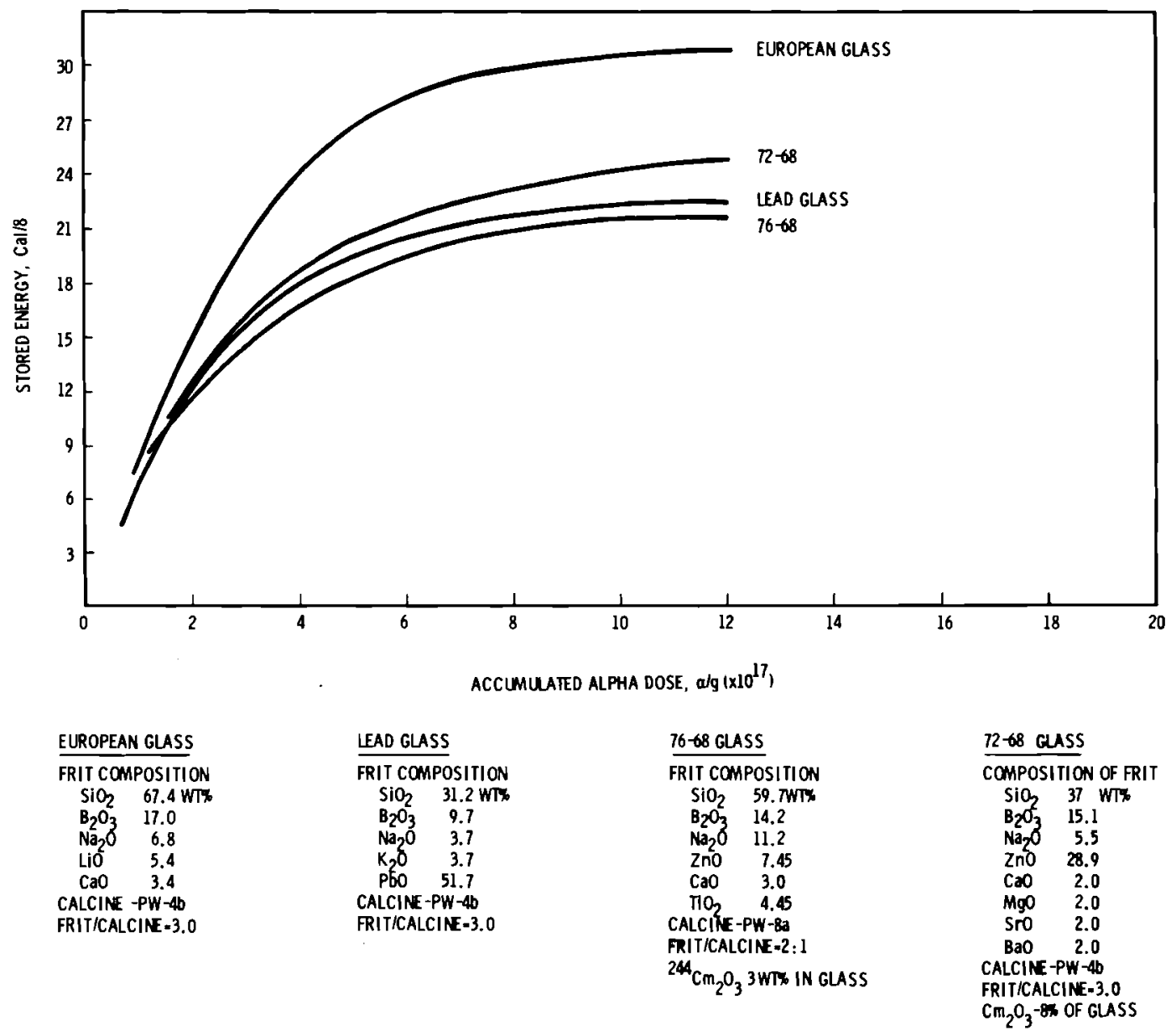

FIGURE 40. Comparison of Stored Energy Buildup in European, Lead, 76-68, and 72-68 Glass 


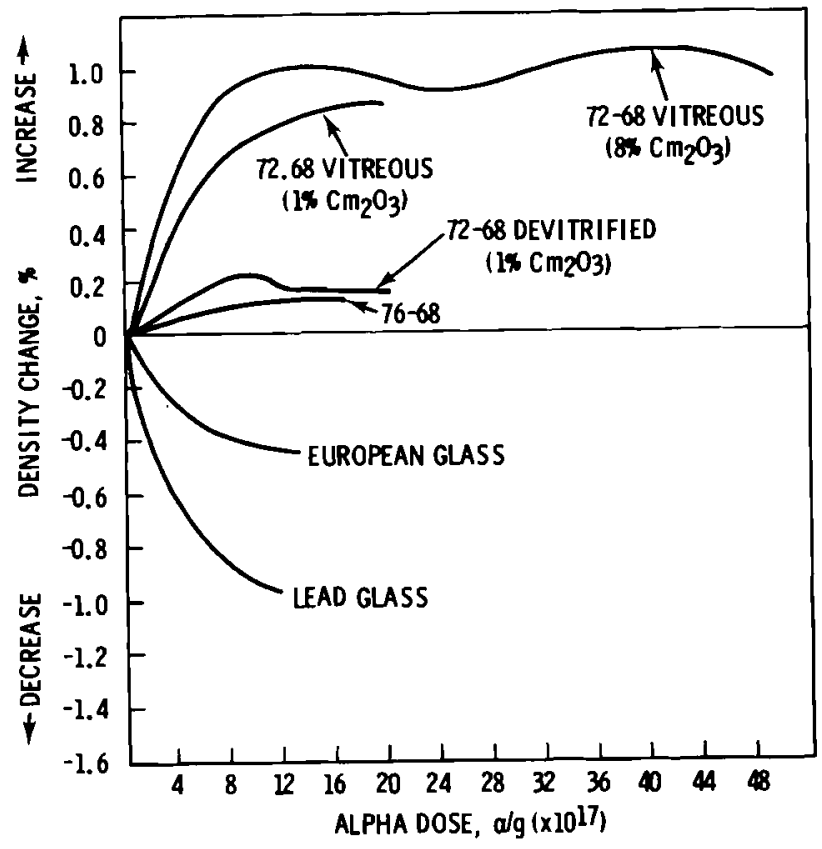

FIGURE 41. Density Changes in AlphaIrradiated Glasses

depends on the degree of devitrification. Density changes resulting from alpha decay are small, even in the worst case, but if necessary, formulations can be developed to minimize the change. The 76-68 glass shows excellent volumetric stability.

One of the difficulties in undertaking accelerated experiments using actinides is that to avoid significantly changing the chemical characteristics of a given glass formulation, the doping levels cannot be too high. In our work, doping levels have been mainly at 1 to 3 wt\% ${ }^{244} \mathrm{Cm}$. At this level, a relatively long time period ( $\sim 1 \mathrm{yr}$ ) is required to reach damage saturation. In the development of improved glasses, it would be desirable to have an index of damage stability in a reasonably short time, for example, within two to four weeks, which is why we are exploring ion bombardment techniques. In addition, enough information is now available from the ${ }^{244} \mathrm{Cm}$ doping work to consider its utilization as a short-time guide to estimate saturation damage effects.

We can measure accurate density changes at an accumulated dose of $10^{17} \mathrm{\alpha} / \mathrm{g}$, but the poor reproducibility of the stored energy measurements at low energy releases would require higher doses to predict saturation values. As a test case, we have considered the data in the preceding figures (and some unpublished results) at $2 \times 10^{17} \alpha / \mathrm{g}$. Figure 42 shows the stored energy and density change values at this dose, plotted against the corresponding maximum values (i.e., $\sim$ saturation) in these properties at higher doses. A reasonable correlation is observed for density, but the correlation for stored energy is probably not linear. For density changes, the correlation is simply: maximum density change $=3.1$ times the density change at $2 \times 10^{17} a / g$.

\section{EXTERNAL BOMBARDMENT STUDIES}

In addition to examining alpha effects, we are studying electron and ion bombardment to learn whether or not we can more easily obtain data than with actinide doping methods. H. E. 

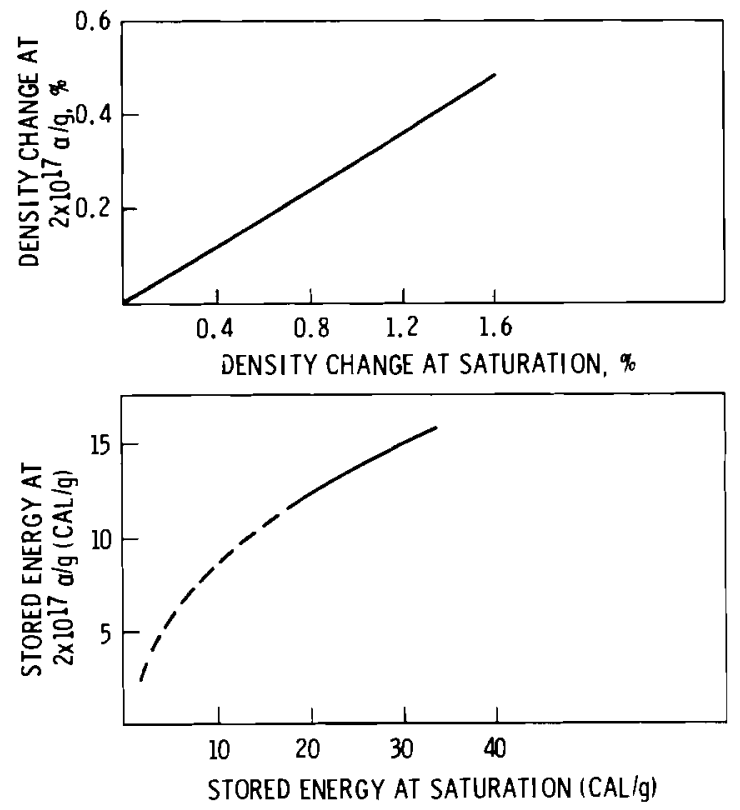

FIGURE 42. Radiation Damage at Saturation Versus Damage at $2 \times 10^{17} \alpha / \mathrm{g}$

Kissinger and $\mathrm{J}$. Brimhall studied proton bombardment of thin sections $\left(7 \mu \mathrm{m} \mathrm{SiO}_{2}\right)$ at PNL. At Argonne, W. Primak is conducting a limited study of electron, proton, and helium bombardment. In addition, one experiment using ${ }^{238} \mathrm{PuO}_{2}$ as a source of alpha particles has been completed at PNL with measurable changes observed.

Since the accelerator work is still incomplete, those results will not be included here. The work with thin sections has not continued because of funding restrictions and some experimental difficulties, particularly beam-heating effects. At Argonne, work with the 76-68 glass composition and its parent glass frit (76-101) does not suggest any unusual changes, compared to a variety of simple glasses. In general, the work there will continue to be exploratory toward establishing an appropriate ranking of waste glasses compared to the common glass types studied previously. A major objective is to determine a damage dose/volume change dependence which can be related to $\mathrm{Cm}$ doping experiments. This would justify use of the technique as a means of estimating damage stability very quickly.

Using ${ }^{238} \mathrm{PuO}_{2}$, we have successfully measured a change in the index of refraction (using an ellipsometer and $\lambda=5461 \AA$ ) as a function of alpha dose, shown in Figure 43 . The experiment involved bringing a polished glass surface (76-68 composition) in near contact with a pellet of ${ }^{238} \mathrm{PuO}_{2}$. The change in index is essentially linear with dose and is negative, suggesting that the associated density is decreasing with alpha dose. In the Cm doping experiments, however, the results given in Figure 41 show that the density increases with the alpha dose. Thus, there is no direct correlation between the more realistic $\mathrm{Cm}$ doping experiment and the external alpha bombardment experiment.

Additional work using external bombardment techniques is needed to resolve these questions. While the effort is limited and progress is slow, we have not ruled out the potential for a rapid tesi. The need is particularly clear when we consider the very broad range of glass compositions and the variable density response observed so far (by Cm doping). 


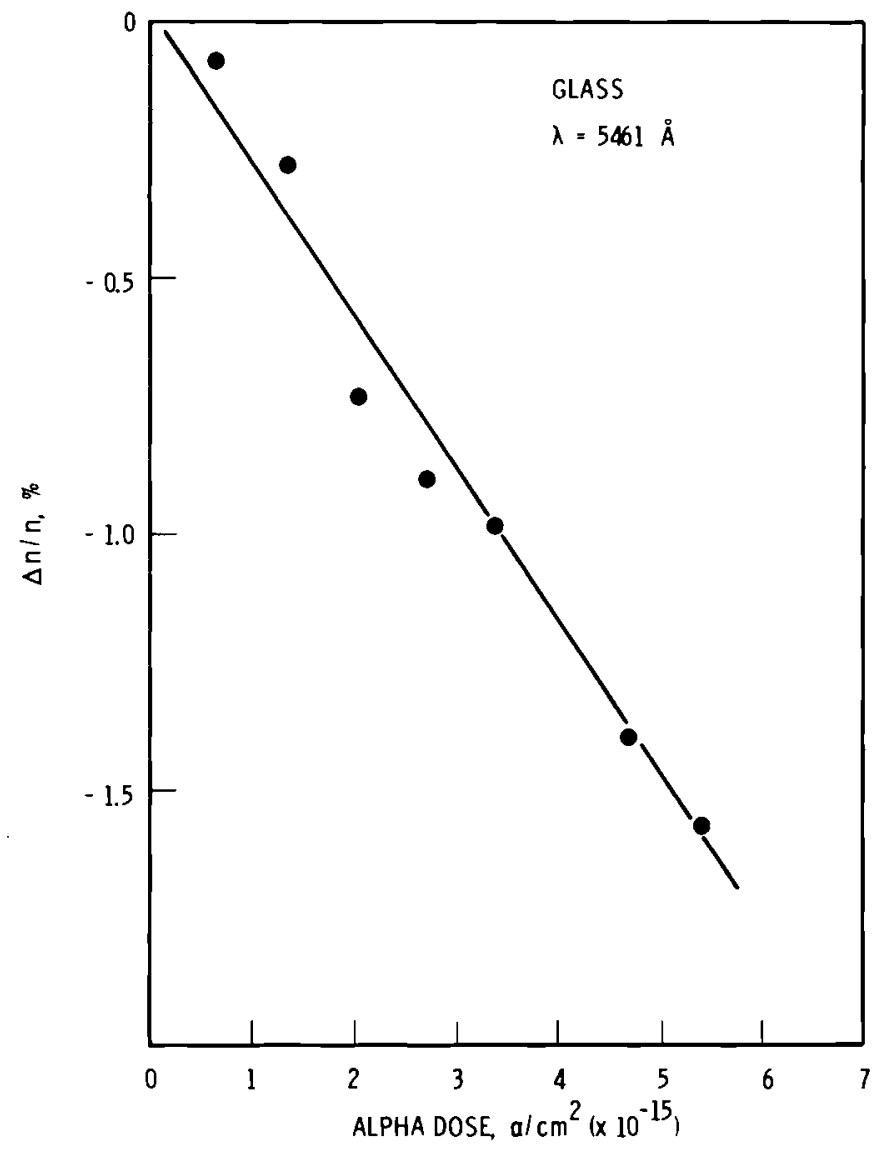

FIGURE 43. Relative Change in the Index of Refraction with Alpha Dose 


\section{REFERENCES}

1. J. E. Mendel, et al., A Program Plan for Comprehensive Craracterization of Solidified High-Level Wastes, BNWL-1940, Battel1e, Pacific Northiwest Laboratories, Richland, WA 99352, Dec. 1975.

2. J. E. Mendel et a1., Annual Report on the Characterization of High-Level Waste Glasses, BNWL-2252, Battelle, Pacific Northwest Laboratories, Richland, WA 99352, June 1977.

3. W. A. Ross, Development of Glass Formulations Containing High-Level Nuclear Wastes, PNL-2481, Battelle, Pacific Northwest Laboratories, Richland, WA 99352, February 1978.

4. T. H. Smith and W. A. Ross, Impact Testing of Vitreous Simulated High-Level Waste in Canisters, BNWL-1903, Battelle, Pacific Northwest Laboratories, Richland, WA 99352, May 1975.

5. S. M. Wiederhorn, "Fracture Surface Energy of Glass," J. Amer. Ceram. Soc., 52(2):99, 1969.

6. R. H. Marion and J. K. Johnstone, Parametric Study of the Diametral Compression Test for Ceramics, SAND-75-0347, Sandia Laboratories, A7buquerque, NM 87107, July 1975.

7. A. Q. Tool and E. E. Hill, "On the Constitution and Density of Glasses," J. Soc. Glass Tech. $9: 185,1925$.

8. W. J. Gray, Volatility of a Zinc Borosilicate Glass Containing Simulated High-Level Radioactive Waste. BWNL-2111, Battelle, Pacific Northwest Laboratories, Richland, WA 99352 , October 1976.

9. H. T. Blair, "In-Can Melting." Quarterly Progress Report, Research and Development Activities, Waste Fixation Program, April through June 1975, BNWL-1932, Battelle, Pacific Northwest Laboratories, Richland, WA 99352, September 1975.

10. R. P. Turcotte and J. W. Wald, Devitrification Behavior in a Zinc Borosilicate Nuclear Waste Glass, PNL-2247, Battelle, Pacific Northwest Laboratories, Richland, WA 99352 , May 1978.

11. F. P. Roberts, G. H. Jenks and C. D. Bopp, Radiation Effects in Solidified High-Level Wastes - Part I, Stored Enerqy, BNWL-1944, Battelle, Pacific Northwest Laboratories, Richland, WA 99352, January 1976.

12. R. P. Turcotte, Radiation Effects in Solidified High-Level Wastes - Part II, Helium Behavior, BNWL-2051, Battelle, Pacific Northwest Laboratories, Richland, WA 99352 , May 1976.

13. G. L. Tingey and W. D. Felix, Radiolytic Gas Generation from Calcined Nuclear Wastes. BNWL-2381, Battelle, Pacific Northwest Laboratories, Richland, WA 99352, August 1977. 


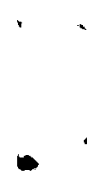

$-$ 


\section{DISTRIBUTION}

No. of

Copies

\section{UNITED STATES}

A. A. Churm

DOE Chicağo Patent Group

9800 South Cass Avenue

Argonne, IL 60439

Deputy Director for Fuels and Materials

NRC Directorate of Licensing for Fuels and Materials

Silver Springs, MD 20910

W. P. Bishop

Assistant Director for Radioactive Waste Management Branch

NRC Division of Materials and

Fuel Cycle Facility Licensing

Washington, DC 20545

W. G. Belter

DOE Division of Biomedical and Environmental Research

Earth Sciences Branch

Washington, DC 20545

W. A. Brobst

DOE Division of Environmental Control Technology

Washington, DC 20545

W. E. Mott

DOE Division of Environmental Control Technology

Washington, DC 20545

G. W. Cunningham

DOE, Administrator for Nuclear Energy Programs

Washington, DC 20545

R. B. Chitwood

DOE Division of Nuclear Power Development

Washington, DC 20545

T. C. Chee

DOE Division of Waste Management Washington, DC 20545

C. R. Cooley

DOE Division of Waste Management

Washington, DC 20545

C. H. George

DOE Division of Waste

Management

Washington, DC 20545
No. of

Copies

C. A. Heath

DOE Division of Waste

Management

Washington, DC 20545

G. Oertel

DOE Division of Waste

Management

Washington, DC 20545

A. F. Perge

DOE Division of Waste

Management

Washington, DC 20545

D. L. Vieth

DOE Division of Waste

Management

Washington, DC 20545

R. D. Walton

DOE Division of Waste

Management

Washington, DC 20545

DOE Idaho Operations Office

P.0. Box 2108

Idaho Falls, ID 83401

J. B. Whitsett

DOE Idaho Operations Office

P. 0 . Box 2108

Idaho Falls, ID 83401

J. J. Schreiber

DOE Oak Ridge Operations

Office

P.0. Box $X$

Oak Ridge, TN 37830

John Van Cleve

DOE Oak Ridge Operations

Office

P.0. Box $X$

Oak Ridge, TN 37830

E. S. Goldberg

DOE Savannah River Operations Office

P. 0. Box A

Aiken, SC 29801

267 DOE Technical Information

Center 
No. of

Copies

A. P. Roeh, Manager

Allied Chemical Corporation

550 2nd Street

Idaho Falls, ID 83401

J. R. Berreth

Allied Chemical Corporation

550 2nd Street

Idaho Falls, ID 83401

R. A. Brown

Allied Chemical Corporation 550 2nd Street

Idaho Falls, ID 83401

C. A. Hawley

Allied Chemical Corporation

550 - 2nd Street

Idaho Falls, ID 83401

D. A. Knecht

Allied Chemical Corporation

550 - 2nd Street

Idaho Falls, ID 83401

Allied Chemical Corporation

(File Copy)

550 - 2nd Street

Idaho Falls, ID 83401

J. A. Buckham

All ied-General Nuclear Service

P. 0. Box 847

Barnwel1, SC 29812

A. Williams

Allied General Nuclear Service

P. 0. Box 847

Barnwe11, SC 29812

J. L. Jardine

Argonne National Laboratory

9700 South Cass Avenue

Argonne, IL 60439

M. M. Steindler/ L. E. Trevorrow Argonne National Laboratory 9700 South Cass Avenue

Argonne, IL 60439

J. M. Batch

Battelle Memorial Institute

505 King Ave.

Columbus, $\mathrm{OH} 43201$

Wayne Carbiener

Battelle Memorial Institute

505 King Ave.

Columbus, $\mathrm{OH} 43201$
No. of

Copies

J. D. Duguid

Battelle Memorial Institute

505 King Ave.

Columbus, $\mathrm{OH} 43201$

R. E. Heineman

Battelle Memorial Institute

505 King Ave.

Columbus, $\mathrm{OH} 43201$

J. Kircher

Battelle Memorial Institute

505 King Ave.

Columbus, OH 43201

Don Moak

Battelle Memorial Institute

505 King Ave.

Columbus, $\mathrm{OH} 43201$

Ken Yates

Battelle Memorial Institute

Rm 13 - 3091

505 King Ave.

Columbus, $\mathrm{OH} 43201$

Brookhaven National Laboratory

Reference Section

Information Division

Upton, Long Island, NY 11973

M. Steinberg

Brookhaven National Laboratory

Upton, Long Island, NY 11973

Combustion Divison

Combustion Engineering, Inc.

Windsor, CT 06095

B. Adams

Corning Glass Works

Technical Staffs Division

Corning, NY 14830

E. Vejvoda, Director

Chemical Operations

Rockwell International

Rocky Flats Plant

P.0. Box 464

Golden, CO 8040

M. D. Boersma

duPont Company, Aiken (DOE)

E. I. duPOnt DeNemours and Company

Savannah River Laboratory

Aiken, SC 29801

C. H. Ice

E. I. duPont DeNemours and Company

Savannah River Laboratory

Aiken, SC 29801 
No. of

Copies

A. S. Jennings

E. I. duPont DeNemours and Company

Savannah River Laboratory

Aiken, SC 29801

Leon Meyers

E. I. duPOnt DeNemours and Company Savannah River Laboratory

Aiken, SC 2980

P. H. Permar

duPont Company, Aiken (DOE)

E. I. duPont DeNemours and Company

Savannah River Laboratory

Aiken, SC 29801

L. Henning

Electric Power Research Institute

3412 Hillview Avenue

P.0. Box 10412

Palo Alto, CA 94304

Environmental Protection Agency

Technology Assessment Division (AW-559)

Office of Radiation Programs

Washington, DC 20460

R. G. Barnes

General Electric Company

175 Curtner Avenue (M/C 160)

San Jose, CA 95125

L. H. Brooks

Gulf Energy and Environmental Systems

P. 0. Box 81608

San Diego, CA 92138

2 Central Research Library

Document Reference Section

Oak Ridge National Laboratory (DOE)

Oak Ridge, TN 37830

3 Los Alamos Scientific

Laboratory (DOE)

P.0. Box 1663

Los Alamos, NM 87544

C. J. Kershner

Monsanto Research Corporation

Mound Laboratory

P. 0. Box 32

Miamisburg, $\mathrm{OH} 45342$
No. of

Copies

John Pomeroy

Technical Secretary

Nationa 1 Academy of Sciences

Committee of Radioactive Waste

Management

Nationa 1 Research Council

2101 Constitution Avenue

Washington, DC 20418

2 J. P. Duckworth

Plant Manager

Nuclear Fuel Services, Inc.

P.0. Box 124

West Valley, NY 14171

J. G. Cline, General Manager

NYS Atomic Space and Development

Authority

230 Park Avenue, RM 2425

New York, NY 10017

Oak Ridge National Laboratory (DOE)

Central Research Library

Document Reference Section

P.0. Box X

Oak Ridge, TN 37830

E. H. Kobish

Solid State Division

Oak Ridge National Laboratory

Oak Ridge, TN 37830

G. J. McGarthy

Pennsylvania State University

Materials Research Laboratory

University Park, PA 16802

D. R. Anderson

Sandia Laboratories

Albuquerque, NM 87107

K. Johnson

Sandia Laboratories

Albuquerque, NM 87107

W. Weart

Sandia Laboratories

Albuquerque, NM 87107

J. Sivinski

Sandia Laboratories

Albuquerque, NM 87107

J. 0. Blomeke

Union Carbide Corporation (ORNL)

Chemical Technology Division

P. 0. Box Y

Oak Ridge, TN 37830 
No. of

Copies

2 D. E. Ferguson

Union Carbide Corporation (ORNL)

Chemical Technology Division

P.0. Box Y

Oak Ridge, TN 37830

H. W. Godbee

Union Carbide Corporation (ORNL)

Chemical Technology Division

P. 0. Box Y

Oak Ridge, TN 37830

W. C. McClain

Union Carbide Corporation (ORNL)

Chemical Technology Division

P.0. Box Y

Oak Ridge, TN 37830

C. D. Zerby

Union Carbide Corporation (ORNL)

Chemical Technology Division

Office of Waste Isolation

P.0. Box $Y$

Oak Ridge, TN 37830

R. A. Beal1

U. S. Department of Interior

Bureau of Mines

Albany Research Center

1450 W. Queen Avenue

Albany, OR 97321

R. G. Post

College of Engineering

University of Arizona

Tucson, AZ 85721

S. E. Logan

University of New Mexico

Albuquerque, NM 87131

\section{FORE IGN}

2 International Atomic Energy Agency

Kärtner Ring 11

P. 0. Box 590

A-1011, Vienna, AUSTRIA

Rene Amavis

EURATOM

Health Physics Division

29, Rue Aldringer

Luxembourg, BELGIUM

\section{G. G. Strathdel}

Atomic Energy of Canada, Ltd.

W.N.R.E. Pinawa, Manitoba

ROE ILO

CANADA
No. of

Copies

M. Tomlinson

Director of Chemistry and

Materials Science Division

Atomic Energy of Canada Lt.d.

Whiteshell Nuclear Research

Establishment

Pinawa, Manitoba, CANADA

K. D. B. Johnson

Atomic Energy Research

Establ ishment,

Harwe11, Didcot,

Berks, ENGLAND

J. A. C. Marples

Atomic Energy Research

Establishment,

Harwel1, Didcot,

Berks, ENGLAND

D. W. Clelland

United Kingdom Atomic Energy Authority

Risley, ENGLAND

P. J. Regnaut

Centre d'Etudes Nucleaires de Fontenay-aux Roses

Boite Postale 6

92 - Fontenay-aux-Roses

FRANCE

Y. J. Sousselier

Center d'Etudes Nucleaires

de Fontenay-aux Roses

Boite Postale 6

92 - Fontenay-aux Roses

FRANCE

Bundesministerium für Forschung und Technologie

Stressemannstrasse 2

5300 Bonn

GERMANY

Center for Atomic Energy

Documentation (ZAED)

Attn: Dr. Mrs. Bell

P. 0. Box 3640

$7500 \mathrm{Kar} 7$ sruhe

GERMANY

Hans W. Levi

Hahn-Meitner Institut

1 Berlin 39

G] ienickerstr. 100

GERMANY 
No. of

Copies

\author{
H. Krause \\ Kernforschungszentrum Karlsruhe \\ GmbH (KfK) \\ Postfach 3640 \\ D7500 Karlsruhe \\ GERMANY
}

R. V. Amalraj

C.W.M.F. Project

P.0. Kalpakkam

Chingleput Dist.

Tamil Nadu, INDIA

N. S. Suder Rajan

Bhabha Atomic Research Centre

Government of India

Hall No. 5

Trombay

Bombay 8S

INDIA

Dr. Piero Risolute,

Head, Radioactive Waste Program

Plant Engineering Dept.

Agip Nucleare

Milano

C. so di Porta Romana, 68

ITALY

F. Gera

CHEN

CSN Casaccia L.I.S.

C.P. 2400, 00100

Rome

ITALY

S. Tashiro

Japan Atomic Energy

Research Institute

Environmental Safety

Research Laboratory

1-1-13, Shibashi

Minatopku, Tokyo

JAPAN

\section{ONSITE}

5 DOE Richland Operations Office
R. B. Goranson
B. D. Guilbeault
M. J. Shupe
D. J. Squires
M. J. Zamorski

11 Rockwell Hanford Operations

H. Babad

R. A. Deju

R. J. Gimera

J. D. Kaser

E. J. Kosiancic

M. J. Kupfer
No. of

Copies

C. M. Manry

J. H. Roecker

W. W. Schultz

D. D. Wodrich

File Copy

3 Exxon Nuclear Company

S. J. Beard

1. Joint Center for Graduate Study

J. Cooper

2. United Nuclear Industries, Inc.

T. E. Dabrowski

A. E. Engler

1 Westinghouse Hanford Company

A. G. Blasewitz

117 Battelle-Northwest

T. W. Ambrose

W. J. Bjorklund

H. T. Blair

W. F. Bonner

D. J. Bradley

J. L. Buelt

R. L. Bunnell

H. C. Burkholder

N. E. Carter

C. C. Chapman

L. A. Chick

T. D. Chikalla

M. O. Cloninger

J. W. Finnigan

A. A. Garrett

W. J. Gray

M. S. Hanson

J. C. Hartl

o. F. Hill

J. H. Jarrett

Y. B. Katayama

W. S. Kelly

R. S. Kemper

D. E. Knowlton

D. K. Kreid

D. E. Larson

J. M. Lukacs

R. P. Marshall

J. L. McElroy (10)

J. S. McPherson (3)

G. B. Mellinger

J. E. Mendel (25)

R. E. Nightingale

D. E. Olesen

C. R. Palmer

A. M. Platt

D. L. Prezbindowski (2)

F. P. Roberts 
No. of

Copies

W. A. Ross (25)

J. M. Rusin

D. H. Siemens

S. C. Slate

R. L. Treat

R. P. Turcotte

H. H. Van Tuy 1

J. W. Waid

W. E. Weber

J. H. Westsik, Jr.

L. D. Williams

W. K. Winegardner

Technical Information (5)

Publishing Coordination (2) 